FUNDAÇÃO UNIVERSIDADE DE BRASÍLIA

INSTITUTO DE CIÊNCIAS BIOLÓGICAS

PROGRAMA DE PÓS-GRADUAÇÃO EM BIOLOGIA MOLECULAR

\title{
CARACTERIZAÇÃO DA ATIVIDADE CITOTÓXICA DA PEÇONHA DE Bothrops marmoratus E EFEITOS DE UMA PLA2- Lys49 ISOLADA SOBRE CÉLULAS DE ADENOCARCINOMA CERVICAL (HeLa) - DO TRANSCRIPTOMA AO PROTEOMA.
}

Jéssica Kele Arruda Macêdo

Orientadora: Profa. Dra. Mariana S. Castro

Tese de doutorado apresentada ao Programa de Pós-Graduação em Biologia Molecular da Universidade de Brasília como parte dos requisitos para obtenção do título de Doutor. 
FUNDAÇÃO UNIVERSIDADE DE BRASÍLIA

INSTITUTO DE CIÊNCIAS BIOLÓGICAS

PROGRAMA DE PÓS-GRADUAÇÃO EM BIOLOGIA MOLECULAR

Tese de doutorado

JÉSSICA KELE ARRUDA MACÊDO

Título:

\section{CARACTERIZAÇÃO DA ATIVIDADE CITOTÓXICA DA PEÇONHA DE Bothrops marmoratus E EFEITOS DE UMA PLA2 Lys49 ISOLADA SOBRE CÉLULAS DE ADENOCARCINOMA CERVICAL (HeLa) - DO TRANSCRIPTOMA AO PROTEOMA}

Comissão Examinadora:

Profa. Dra. Mariana de Souza Castro, CFS/UnB

Dr. Richard Hemmi Valent, Fiocruz/RJ

Profa. Dra. Graziela Joanitti, FEC/UnB

Profa. Dra. Andrea Barretto Motoyama, FS/UnB

Profa. Dra. Eliane F. Noronha, CEL/UnB

Prof. Dr. Osmindo Rodrigues Pires Júnior, CFS/UnB (suplente) 
1 - Identíficação do Aluno

Secretaria de Administração Acadêmica - SAA

Nome

Jessica Kele Arruda Macedo

Matricula

Curso

Ciências Biológicas

Área de Concentração

Código

Biologia Molecular

2275

$11 / 0089685$

2 - Sessáo de Defesa de Tese

Título

"CARACTERIZACÃO DA ATIVIDADE CITOTÓXICA DA PECONHA DE BOTHROPS MARMORATUS E EFEITOS DE UMA PLA2-LYS49 ISOLADA SOBRE CÉLULAS DE ADENOCARCINOMA CERVIAL (HeLa) - do transcriptoma ao proteoma"

3-Comissäo Examinadora
MARIANA DE SOUZA CASTRO (Doutor)

4. Resultado

A Comissão Examinadora, em 09/06/2015 após exame da Defesa de Tese e argüição do candidato, decidiu:

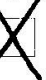

Pela aprovação da Tese

Pela aprovação da Tese, com revisão de forma, indicando o prazo de até 30 dias

para apresentação definitiva do trabalho revisado.

Pela reprovação da Tese

Pela reformulação da Tese, indicando o prazo de para nova versão.

Preencher somente em caso de revisão de forma:

O aluno apresentou a revisão de forma e a Tese foi aprovada.

O aluno apresentou a revisão de forma e a Tese foi reprovada.

O aluno não apresentou a revisão de forma.

Autenticação

Presidente da Comissão Examinadora

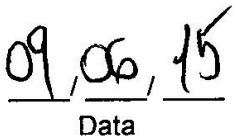

Ciente

Aluno
Autenticação

Coordenador do Curso

Este relatório não é conclusivo e não tem efeitos legais sem a aprovação do Decanato de Pesquisa e Pós-graduação da Universidade de Brasília.

Aprovaçăo do Decanato de Pesquisa e Pós-Graduação

Decisão:

Homologar

$-\frac{1}{\text { Data }}$

Assinatura do Decano 
Dedico essa tese de doutorado à minha família, Marcos, Tereza, Bárbara, Stéfane e Marcos Willian por todo amor e apoio incondicional. Vocês são para mim modelo de determinação, honestidade e trabalho com excelência. 0 amor e compreensão de vocês me deram a força necessária para seguir nos momentos mais difíceis. Vocês estiveram sempre presente, e isso me deu segurança e certeza de que não estou sozinha nessa caminhada. AMO VOCÊS!! 


\section{AGRADECIMENTOS}

"Quem caminha sozinho pode até chegar mais rápido, mas aquele que vai acompanhado, com certeza vai mais longe."

Clarice Lispector

Agradeço em primeiro lugar a Deus que iluminou o meu caminho durante todo esse tempo e me deu saúde, força e coragem.

À Profa. Dra. Mariana de Souza Castro pelos ensinamentos e confiança mais uma vez. E por ter me incentivado a literalmente ir mais longe.

Ao Dr. Jay W. Fox da Universidade da Virgínia pelos ensinamentos, pelas inúmeras oportunidades, confiança, cuidado e carinho inesquecíveis. Agradeço também aos outros colaboradores de seu laboratório, Julie Burns, Drs. John Shannon, Erin Jeffery e Nicholas Sherman.

Ao Prof. Dr. Osmindo Rodrigues Pires Jr. pelos ensinamentos e por estar sempre, sempre presente quando precisei.

À prof. Msc. Marta Regina Magalhães do CEPB - PUC Goiás por novamente fornecer a peçonha, sem a qual esse trabalho seria impossível.

Aos professores do Laboratório de Bioquímica e Química de Proteínas, Dr. Wagner Fontes, Dr. Carlos André O. Ricart, Dra. Consuelo Medeiros e Dr. Marcelo V. de Sousa pela disponibilização de materiais, equipamentos, pelos ensinamentos e momentos de descontração.

À amiga Dra Graziella Joanitte, não apenas pela inestimável ajuda com os ensaios citotóxicos, mas por ter me apoiado, por ser tão prestativa e por ter me ensinado muito sobre ser cientista e acreditar que tudo vai dar certo.

Ao Dr. Ricardo Bentes Azevedo do laboratório de morfologia e morfogênese por disponibilizar a estrutura para realização dos ensaios citotóxicos.

Aos companheiros de doutorado, Andrea, Alininha, Rosa e César pela parceria e apoio constantes. Pelas alegrias, dores e esforços compartilhados. Com vocês, o dia a dia foi muito mais produtivo e as pausas se tornaram um oásis.

Aos queridos com quem convivi ao longo desses anos. A produção compartilhada na comunhão com amigos foi a melhor experiência da minha formação. Obrigada pela companhia e carinho Solange, Ana Carolina, Caroline Barbosa, Natiela, Ana Carolline, Micaella, Anne, Diana, Elaine, Simone, Helena, Marina e Adolfo. Agradeço também ao Adelson, Jaques, Nicholas, Arthur, Carlos, Samuel, Rodrigo, Agnelo (Navalhaaada), pelos divertidos momentos e interrupções. Vocês são todos muito especiais para mim. Especialmente ao Rayner pela companhia e por estar sempre disposto a ajudar. Vocês tornaram cada dia especial... muito especial!! 
Deixo aqui meu agradecimento muito especial à essas pessoas que indiretamente contribuíram para a concretização desse trabalho. Pessoas que completaram minha vida trazendo ricas experiências durante esses anos e sem as quais minha vida se resumiria em conquistas profissionais.

"A amizade é um amor que nunca morre" Mario Quintana

À minha família brasiliense João, Ana, Luciana, Lucas e Ester. 0 que dizer de vocês? Vocês merecem um lugar de destaque. Não existem palavras que expressem minha gratidão e o quanto eu amo cada um profundamente e para sempre. Obrigada por acreditarem em mim, pela confiança e suporte.

Às aminhas amigas Cristiane Mota, Graziela Valadão, Vanessa Brandão, Débora Siqueira e Janaína Amorim. Vocês se revelaram verdadeiras amigas me apoiando durante todos esses anos e me segurando as mãos quando eu pensava não conseguir mais caminhar. Vocês estão em minhas melhores lembranças. Agradeço a vocês por terem enriquecido minha vida, por terem se doado e tocado minha alma.

Aos amigos conquistados durante meu estágio nos EUA. Todos são especiais e vou guardar eternas e doces lembranças. Alguns, no entanto foram tão presentes e intensos que ainda permanecem comigo todos os dias, mesmo que distantes. Vou carrega-los por toda vida. Vocês foram sem dúvidas o que de melhor me aconteceu e mudaram a minha vida para sempre. Eu poderia escrever uma outra tese só com nossas memórias... Os brazucas Juliana, Otília, Felipe, Gabriela e Bruno. Obrigada pela força, meus amores. Vocês são uns heróis, meus fortes e bravos heróis. Aos amados Gregory, Agata, Piotr, Yussi e Dave que muito me ajudaram em diferentes momentos. Amo vocês do fundo da minha alma e agradeço por cada experiência que me proporcionaram. Me encho de alegria só de pensar em vocês. Obrigada por serem exatamente como são. 


\section{APOIO FINANCEIRO}

A tese de doutorado intitulada "Caracterização da atividade citotóxica da peçonha de Bothrops marmoratus e efeitos de uma PLA2-Lys49 isolada sobre células de adenocarcinoma cervical (HeLa) - do transcriptoma ao proteoma" desenvolvida por Jéssica Kele Arruda Macêdo sob a orientação da Profa. Dra. Mariana S. Castro teve o apoio financeiro do CNPq (processos no. 211771/2013-9, bolsa de doutorado sanduíche realizado na University of Virginia, USA; no. 563972/2010-6, Edital MCT/CNPq/FNDCT/FAPs/MEC/CAPES/PRÓ-CENTRO-OESTE no. 31/2010; no. 302925/2012-0, Produtividade em Pesquisa - PQ - 2012; no. 407801-2013, Rede Centro-Oeste de Pós-Graduação, Pesquisa e Inovação - REDE PRÓ-CENTRO-OESTE), da FAPDF (processo no. 193.000.461/2011, Edital MCT/CNPq/FNDCT/FAPs/MEC/CAPES/PRÓ-CENTRO-OESTE no 31/2010), da CAPES por meio da concessão de bolsa de estudos, da FINEP (CT-INFRA) e da FUB-UnB. 
"Estamos na situação de uma criancinha que entra em uma imensa biblioteca, repleta de livros em muitas línguas. A criança sabe que alguém deve ter escrito aqueles livros, mas não sabe como. Não compreende as línguas em que foram escritos. Tem uma pálida suspeita de que a disposição dos livros obedece a uma ordem misteriosa, mas não sabe qual ela é"

Albert Einstein 


\section{SUMÁRIO}

LISTA DE ABREVIATURAS...........................................................................................

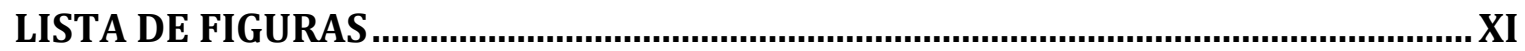

LISTA DE TABELAS ..................................................................................................

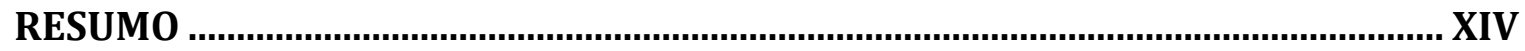

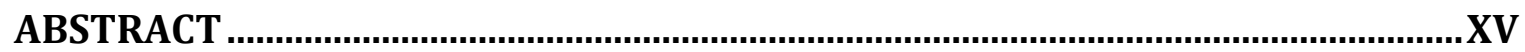

1. INTRODUÇÃO ................................................................................................... 2

1.1. HOMEOSTASIA TECIDUAL …………………

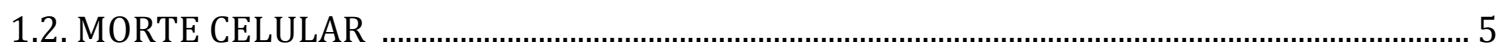

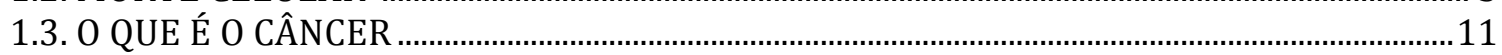

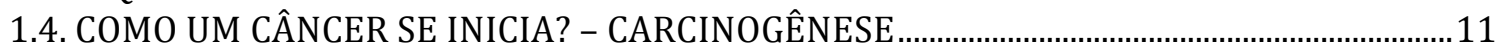

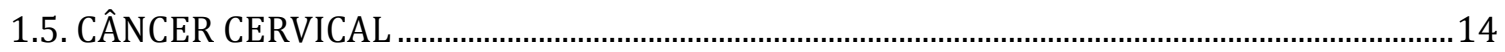

1.6. POTENCIAL BIOTECNOLÓGICO DAS PEÇONHAS DE SERPENTES .........................................15

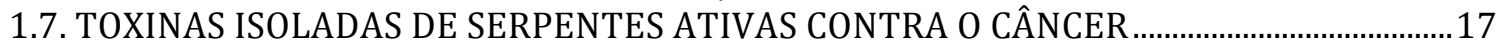

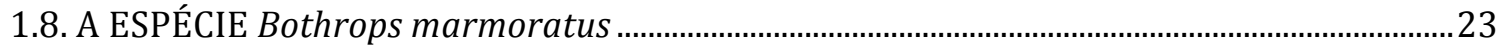

1.9. ESTUDOS JÁ REALIZADOS COM ESSA PEÇONHA …..........................................................2

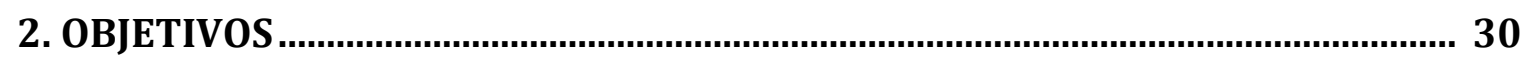

3. MATERIAIS E MÉTODOS ..................................................................................... 32

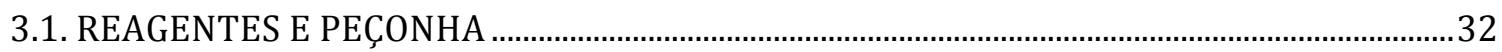

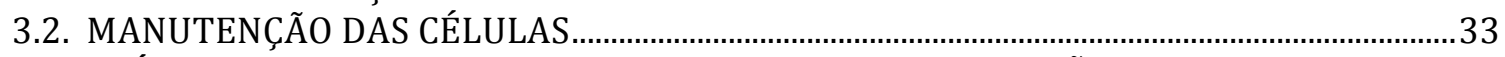

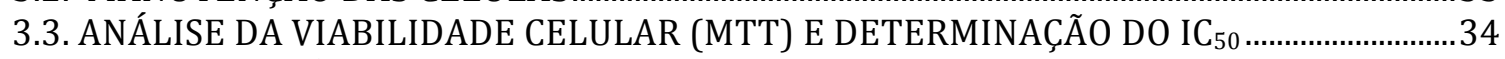

3.4. DETERMINAÇÃO DA INTEGRIDADE DE MEMBRANA CELULAR E APOPTOSE .................35

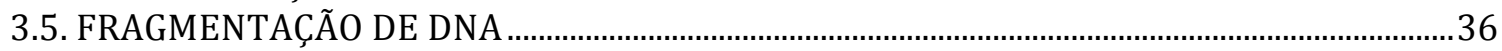

3.6. DISTRIBUIÇÃO DE CÉLULAS NO CICLO CELULAR......................................................................

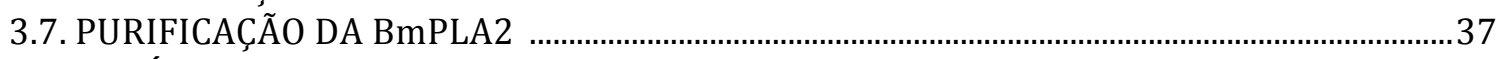

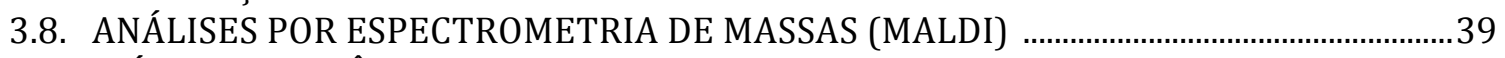

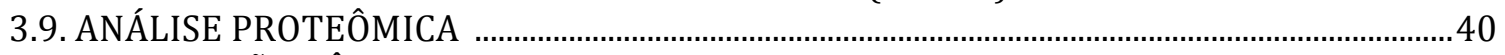

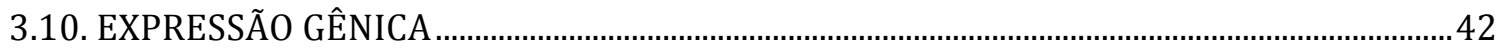

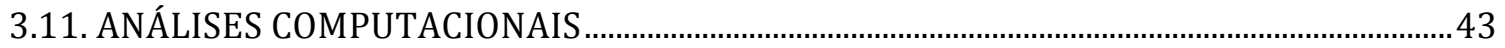

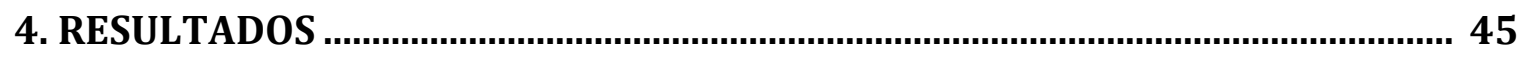

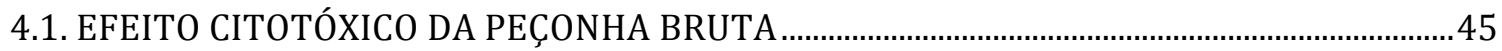

4.2. PURIFICAÇÃO DA BmPLA2 E DETERMINAÇÃO DO SEU GRAU DE HOMOGENEIDADE.48

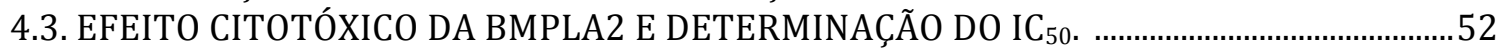

4.4. AVALIAÇÃO DA EXPRESSÃO GÊNICA DE CÉLULAS HeLa TRATADAS COM A BmPLA2.53

4.5. ANÁLISE PROTEÔMICA DE CÉLULAS HeLa tratadas com a BmPLA2 …………………….....63

4.6. EXPRESSÃO GÊNICA X PROTEÔMICA ……………..................................................................69

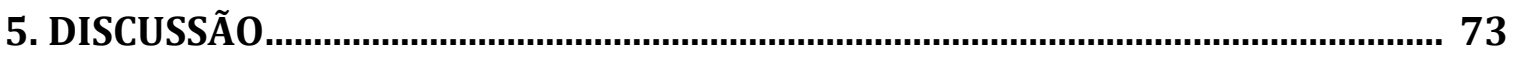

6. CONCLUSÕES E PERSPECTIVAS............................................................................ 97

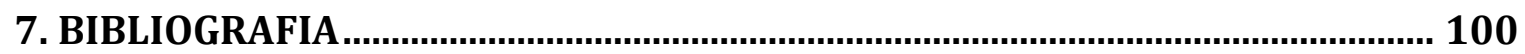




\section{LISTA DE ABREVIATURAS}

$\begin{array}{ll}{[\mathrm{M}+\mathrm{H}]^{+}} & \text {Massa molecular monoisotópica } \\ \text { Abs } & \text { Absorbância } \\ \text { ACN } & \text { Acetonitrila } \\ \text { ATCC } & \text { Coleção de Cultura Tipo Americana, do inglês American Type Culture } \\ & \text { Collection } \\ \text { BSA } & \text { Albumina sérica bovina, do inglês bovine serum albumin } \\ \text { DMEM } & \text { Meio Eagle Modificado por Dulbecco, do inglês Dulbecco's Modified } \\ & \text { Eagle's Medium } \\ \text { DMSO } & \text { Dimetilsulfóxido } \\ \text { DTT } & \text { Ditiotreitol } \\ \text { ECM } & \text { Matriz extracelular, do inglês extracellular matrix } \\ & \\ \text { EDTA } & \text { Ácido etilenodiaminotetraacético } \\ \text { Fold change } & \text { Razão entre o valor do grupo controle e o grupo tratado } \\ \text { HC } 50 & \text { Concentração capaz de promover 50\% de hemólise } \\ \text { HCCA } & \text { Ácido } \alpha \text {-ciano-4-hidroxicinâmico } \\ \text { HPLC } & \text { Cromatografia líquida de alta eficiência, do inglês High Performance } \\ & \text { Liquid Chromatography } \\ \text { IC } 50 & \text { Concentração capaz de inviabilizar 50\% das células } \\ \text { m/z } & \text { Relação massa/carga } \\ \text { MALDI-TOF } & \text { Matrix Assisted Laser Desorption Ionization-Time of Flight } \\ \text { MM } & \text { Massa molecular } \\ \text { MS } & \text { Espectrometria de massas, do inglês mass spectrometry } \\ \text { MTT } & \text { Brometo de 3-(4,5-dimetiltiazol-2-il)-2,5-difeniltetrazólio } \\ \text { PBS } & \text { Tampão fosfato de sódio, do inglês phosphate buffered saline } \\ \text { PDB } & \text { Protein Data Bank } \\ \text { PLA2 } & \text { Fosfolipase A2 } \\ \text { RP-HPLC } & \text { Cromatografia líquida de alta eficiência em fase reversa, do } \\ & \text { inglês Reversed-Phase High Performance Liquid Chromatography } \\ \text { rpm } & \text { Rotações por minuto } \\ \text { SA } & \text { Ácido sinapínico, do inglês Sinapinic acid } \\ \text { TFA } & \text { Ácido trifluoroacético, do inglês Trifluoroacetic acid } \\ \text { TNF } & \text { Fator de necrose tumoral, fo inglês Tumor necrosis factor. } \\ & \end{array}$




\section{LISTA DE FIGURAS}

Figura 1| Resposta celular aos danos no DNA ............................................................... 2

Figura 2| Ciclo celular e os pontos de checagem do DNA..................................................... 3

Figura 3| Características morfológicas de uma célula normal, autofágica, apoptótica e necrótica

Figura 4| Etapas da patogênese tumoral e seu microambiente.

Figura 5| Hidrólise de fosfatidilcolina pela PLA1, PLA2, PLB, PLC e PLD e os respectivos produtos da reação........................................................................................ 19

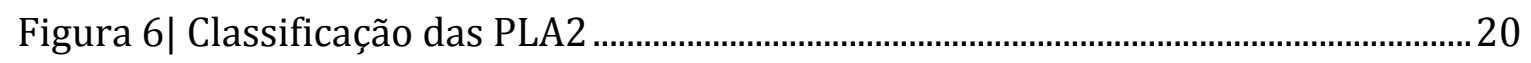

Figura 7| Mapas evidenciando (A) a distribuição geográfica da espécie $B$. marmoratus e (B) a sobreposição das distribuições geográficas das espécies do

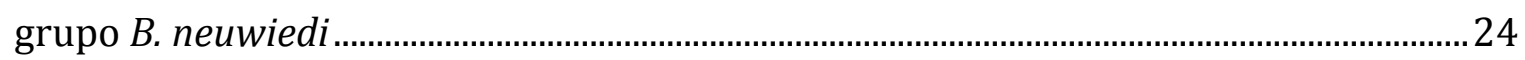

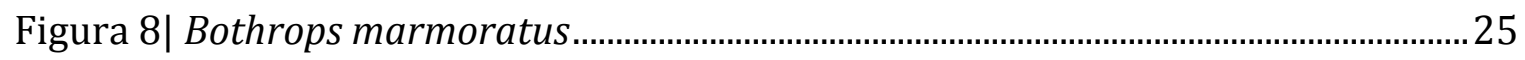

Figura 9| Fluoxograma do desenho experimental utilizado para desenvolvimento da metodologia.

Figura 10| Ilustração esquemática de todas as etapas testadas inicialmente na purificação da fosfolipase A2 de Bothrops marmoratus.

Figura 11| Porcentagem de morte celular causada pela peçonha bruta de $B$.

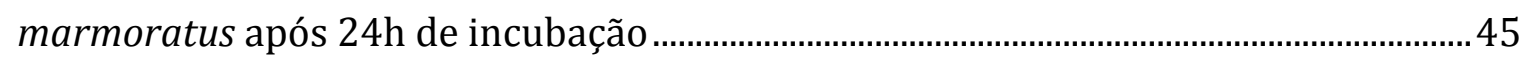

Figura 12| Quantificação da apoptose e necrose em células HeLa por citometria de fluxo utilizando Anexina V-FITC e PI.

Figura 13| Porcentagem de DNA fragmentado após o tratamento com a peçonha de B. marmoratus por $24 \mathrm{~h}$.

Figura 14| Proporção de células nas diferentes fases do ciclo celular tratadas ou não com a peçonha de B. marmoratus por 24 horas

Figura 15| Perfil cromatográfico da peçonha bruta de B. marmoratus em coluna de Troca iônica.

Figura 16| Perfil cromatográfico da peçonha bruta de B. marmoratus em coluna de exclusão molecular. 
Figura 17| Viabilidade celular (\%) das células tumorais HeLa e MCF7 após incubação por $24 \mathrm{~h}$ com as frações cromatográficas da peçonha de B. marmoratus obtidas por cromatografia de exclusão molecular

Figura 18| Purificação em coluna de fase reversa, avaliação do grau de homogeneidade e determinação da massa molecular da BmPLA2 isolada da peçonha de B. marmoratus 52

Figura 19| Diminuição da viabilidade celular causada pelo tratamento com a BmPLA2 por $24 \mathrm{~h}$

Figura 20| Genes identificados como diferencialmente expressos em células tratadas com a BmPLA2 por $2 \mathrm{~h}, 12 \mathrm{~h}$ ou $24 \mathrm{~h}$ totalizando 1.964 genes. .54

Figura 21| Perfil de expressão gênica de células HeLa tratadas por diferentes tempos com a BmPLA2.

Figura 22| Via MAPK com marcação dos genes alterados em células HeLa tratadas por diferentes tempos com BmPLA2 57

Figura 23| Mudança na expressão de genes relacionados à via de sinalização MAPK em células HeLa tratadas por diferentes tempos com a BmPLA2 .58

Figura 24| Mudança na expressão de genes relacionados à via autofágica em células HeLa tratadas por diferentes tempos com BmPLA2

Figura 25| Via apoptótica com marcação dos genes alterados em células HeLa tratadas por diferentes tempos com a BmPLA2.

Figura 26| Mudança na expressão de genes relacionados à via apoptótica em células HeLa tratadas por diferentes tempos com BmPLA2

Figura 27| Mudança na expressão de genes relacionados à adesão focal em células HeLa tratadas por diferentes tempos com a BmPLA2.

Figura 28| Gel desnaturante SDS-PAGE do extrato de células (HeLa) tratadas com na concentração equivalente ao $\mathrm{IC}_{50}$ da BmPLA2 ou com salina por $24 \mathrm{~h}$

Figura 29| Diagrama de dispersão das proteínas identificadas por LC-MS.

Figura 30| Comparação das alterações de expressão gênica versus síntese proteica em células HeLa tratadas com a BmPLA2 70 


\section{LISTA DE TABELAS}

Tabela 1| Lista de toxinas isoladas de serpentes do grupo neuwiedi.

Tabela 2| Principais vias biológicas alteradas em células HeLa tratadas com a BmPLA2 a partir dos dados obtidos pela análise transcriptômica.

Tabela 3| Principais vias biológicas alteradas em células HeLa tratadas com a BmPLA2 a partir dos dados obtidos pela análise proteômica.............................................66

Tabela 4| Proteínas relacionadas à morte celular, adesão focal e autofagia com alteração considerada significativa. Resultados obtidos por análise proteômica de células HeLa tratadas com BmPLA2 por 24 horas...............................................................67

Tabela 5| Proteínas relacionadas à morte celular e adesão focal ausentes em uma das amostras e presente em outra. Resultados obtidos por análise proteômica de células HeLa tratadas com BmPLA2 por 24 horas. 68 
CARACTERIZAÇÃO DA ATIVIDADE CITOTÓXICA DA PEÇONHA DE Bothrops marmoratus E EFEITOS DE UMA PLA2-LYS49 ISOLADA SOBRE CÉLULAS DE ADENOCARCINOMA CERVICAL (HeLa) - DO TRANSCRIPTOMA AO PROTEOMA.

\section{RESUMO}

Introdução: A emergência contra a resistência de células tumorais às drogas quimioterápicas disponíveis no mercado faz com que o desenvolvimento de novos agentes seja de grande importância. As toxinas isoladas de venenos animais, incluindo serpentes, têm disso sujeitos de numerosos estudos devido ao seu potencial biotecnológico e aplicações médicas. Objetivos: Foram investigados os efeitos provocados pelo tratamento de diversas linhagens celulares com a peçonha bruta de B. marmoratus, bem como os efeitos de uma PLA2 cataliticamente inativa isolada (BmPLA2) sobre células HeLa. Métodos: A abordagem experimental para análise da peçonha bruta incluiu principalmente detecção da viabilidade celular e caracterização do tipo de morte celular por citometria de fluxo. Para análise das alterações transcriptômicas provocadas pelo tratamento com BmPLA2 por $2 \mathrm{~h}, 12 \mathrm{~h}$ ou 24 h RNA extraído foi analisado por microarranjo utilizando Affymetrix GeneChip® Human Gene 2.0 ST. As alterações proteômicas também foram analisadas por meio da descomplexação do lisado protéico utilizando SDS-PAGE, seguida por analise por LC / MS / MS.Resultados: A análise dos resultados permitiu a verificação de morte celular apoptótica causada pela peçonha bruta com $\mathrm{IC}_{50}$ de 5 $\mu \mathrm{g} / \mathrm{mL}$ para HeLa, 2,5 $\mu \mathrm{g} / \mathrm{mL}$ para B16F10 e 2,2 $\mu \mathrm{g} / \mathrm{mL}$ para NIH/3T3. Por outro lado, o IC 50 determinado para BmPLA2 foi de 8,7 $\mu \mathrm{M}$. Os dados de transcriptômica e proteômica juntos, demonstraram as mudanças típicas associadas à apoptose bem como associadas a outras vias importantes como MAPK, adesão focal e autofagia, produzindo insights sobre os mecanismos que levam à morte celular. Conclusões: BmPLA2 induz morte de células tumorais via apoptose, mas pode por outro lado ativar mecanismos relacionados à resistência e sobrevida, sendo portanto necessário a confirmação dessas vias, bem como uma análise mais detalhada e a longo prazo para determinação efetiva do seu efeito.

Palavras-chave: veneno, câncer, proteômica, transcriptômica, apoptose, fosfolipase. 
CHARACTERIZATION OF CYTOTOXIC ACTIVITY FROM Bothrops marmoratus VENOM AND EFFECTS OF A Lys49-PLA2 ISOLATED ON ADENOCARCINOMA CELLS CERVICAL (HeLa) - FROM TRANSCRIPTOME TO PROTEOME.

\begin{abstract}
Introduction: The emergence against tumor cell resistance to chemotherapy drugs available in the market makes the development of new agents of great importance. The toxins isolated from animals including snake venoms have been subject of numerous studies due to their potential on biotechnological and medical applications. Objectives: The effects caused by treatment of different cell lines with crude venom of B. marmoratus, as well as the effect of a catalytically inactive PLA2 isolated (BmPLA2) were investigated on HeLa cells. Methods: The experimental approach for analysis of crude venom included mainly detection of cell viability and characterization of cell death by flow cytometry. For analysis of transcriptomic changes caused by treatment with BmPLA2 for $2 \mathrm{~h}, 12 \mathrm{~h}$ and $24 \mathrm{~h}$, extracted RNA was analyzed by microarray using Affymetrix GeneChip ${ }^{\circledR}$ Human Gene 2.0 ST. The proteomic alterations were also analyzed by decomplexation of protein lysate using SDS-PAGE followed by analysis by LC / MS / MS. Results: The results allowed the verification of apoptotic cell death caused by crude venom with IC50 of $5 \mu \mathrm{g} / \mathrm{ml}$ to HeLa, $2.5 \mu \mathrm{g} / \mathrm{ml}$ for B16F10 and $2.2 \mu \mathrm{g} / \mathrm{ml}$ for NIH / 3T3. On the other hand, the IC50 for BmPLA2 was $8.7 \mu \mathrm{M}$. The transcriptomic and proteomic data together, showed typical changes associated with apoptosis and associated with other pathways such as MAPK, focal adhesion and autophagy, yielding insights into the mechanisms that lead to cell death. Conclusions: BmPLA2 induces tumor cell death via apoptosis but can on the other hand, elicit mechanisms related to the resilience and survival. It is still necessary to confirm these pathways, as well as perform some additional detailed analysis and long-term effective to determine their effect.
\end{abstract}

Keywords: venom, cancer, proteomics, transcriptomics, apoptosis, phospholipase. 
1. INTRODUÇÃO 


\section{INTRODUÇÃO}

\subsection{HOMEOSTASIA TECIDUAL}

A divisão celular é um processo pelo qual uma célula se multiplica, originando duas ou mais células filhas semelhantes à célula materna ou progenitora, processo que mantém o equilíbrio e a vida de um tecido. 0 crescimento e replicação das células ocorrem devido a uma sequência complexa de eventos dentro do chamado ciclo celular. Esses eventos são controlados principalmente por dois tipos de genes, os oncogenes (Her2/Neu, Ras, c-Myc) e os genes supressores de tumor (p53 e RB). Os oncogenes ou proto-oncogenes são responsáveis pela produção de proteínas que atuam na estimulação do ciclo celular, enquanto os genes supressores de tumor são responsáveis pela produção de proteínas que atuam inibindo o ciclo celular. O equilíbrio na atuação desses dois grupos de genes resulta no perfeito funcionamento do ciclo celular (Hartwell \& Kastan, 1994; Foster, 2008).

O estímulo para o crescimento começa a partir da liberação de fatores de crescimento que se ligam a receptores sobre a membrana celular. Os sinais são, em seguida, transportados por proteínas através da membrana que, por sua vez, sinaliza a liberação de fatores de transcrição no núcleo. Esta sequência de eventos é o que promove a progressão do ciclo celular nas células (Vermeulen et al., 2003).

Didaticamente, o ciclo celular é dividido em intérfase e mitose. Durante a intérfase ocorre uma intensa atividade metabólica, pois é nesse período que ocorre a duplicação do material genético da célula. A mitose, por sua vez, é a divisão celular propriamente dita (Kastan \& Bartek, 2004).

A intérfase pode ser dividida em três fases. A fase G1 é o período em que a célula não recebe estímulo para iniciar uma nova divisão, apenas passa por períodos de crescimento, diferenciação e produção de substâncias, como proteínas, ou a célula pode parar temporariamente, entrando na fase G0. As células em G0 encontram-se em um estado quiescente no qual permanecem metabolicamente ativas, mas, em geral, não se dividem. Na fase seguinte, chamada de $S$, ocorre a síntese de DNA. Esta fase deve ser completada tão rapidamente quanto possível, uma vez que o DNA é muito sensível a danos durante esta fase. Ao final desta etapa, a célula contará com seu DNA todo duplicado para prosseguir para a fase G2. Nesta fase, a célula se prepara para a duplicação que ocorrerá na fase M produzindo as 
substâncias necessárias e duplicando organelas (Foster, 2008; Kastan \& Bartek, 2004).

Durante essas etapas, o genoma das células eucarióticas está sob ataque constante de diversas fontes e por isso muitos danos podem surgir no DNA, levando a um processo carcinogênico, seja por agentes ambientais, tais como a radiação ultravioleta da luz solar (UV), radiações ionizantes, exposição a produtos químicos genotóxicos, ou seja por ameaças endógenas, como subprodutos do metabolismo celular normal do indivíduo, como as espécies reativas de oxigênio (ROS) geradas com a respiração oxidativa e produtos da peroxidação lipídica (Houtgraaf et al., 2006).

Para manter a célula protegida existem mecanismos pelos quais o DNA pode ser reparado, garantindo a sobrevivência e propagação de cópias exatas do genoma nas gerações seguintes. Em células em proliferação, pontos de checagem podem ser ativados conduzindo a uma paralisação do ciclo celular e ativando a maquinaria de reparo do DNA, caso seja necessário. Em células em repouso ou terminalmente diferenciadas, a reparação do DNA é iniciada diretamente e só então a célula continua o ciclo celular. Se o dano não puder ser reparado ou se for demasiado para a maquinaria de reparação do DNA, o ciclo celular pode ser bloqueado de forma permanente, levando a um estado senescente da célula ou à indução da apoptose. Se os danos não reparados passarem despercebidos, mutações e instabilidade genômica podem levar à oncogênese (Houtgraaf et al., 2006). Um esquema mostrando os caminhos que a célula pode percorrer quando ocorre dano ao DNA está ilustrado na figura 1.

Em geral, esses pontos de checagem têm a finalidade de verificar se a célula em divisão tem as características necessárias para se dividir como: tamanho adequado, nutrientes suficientes e ausência de alterações no DNA (Molinari, 2000; Lukas et al., 2004). Os mecanismos de reparo são ativados quando essas alterações são reconhecidas por sensores, o que leva à ativação de uma série de quinases que, por sua vez, podem participar do controle do ciclo celular. Dependendo da fase do ciclo celular quando ocorrerem danos e o modo de danos no DNA, as células podem ativar vias distintas (Medema \& Macůrek, 2012). 


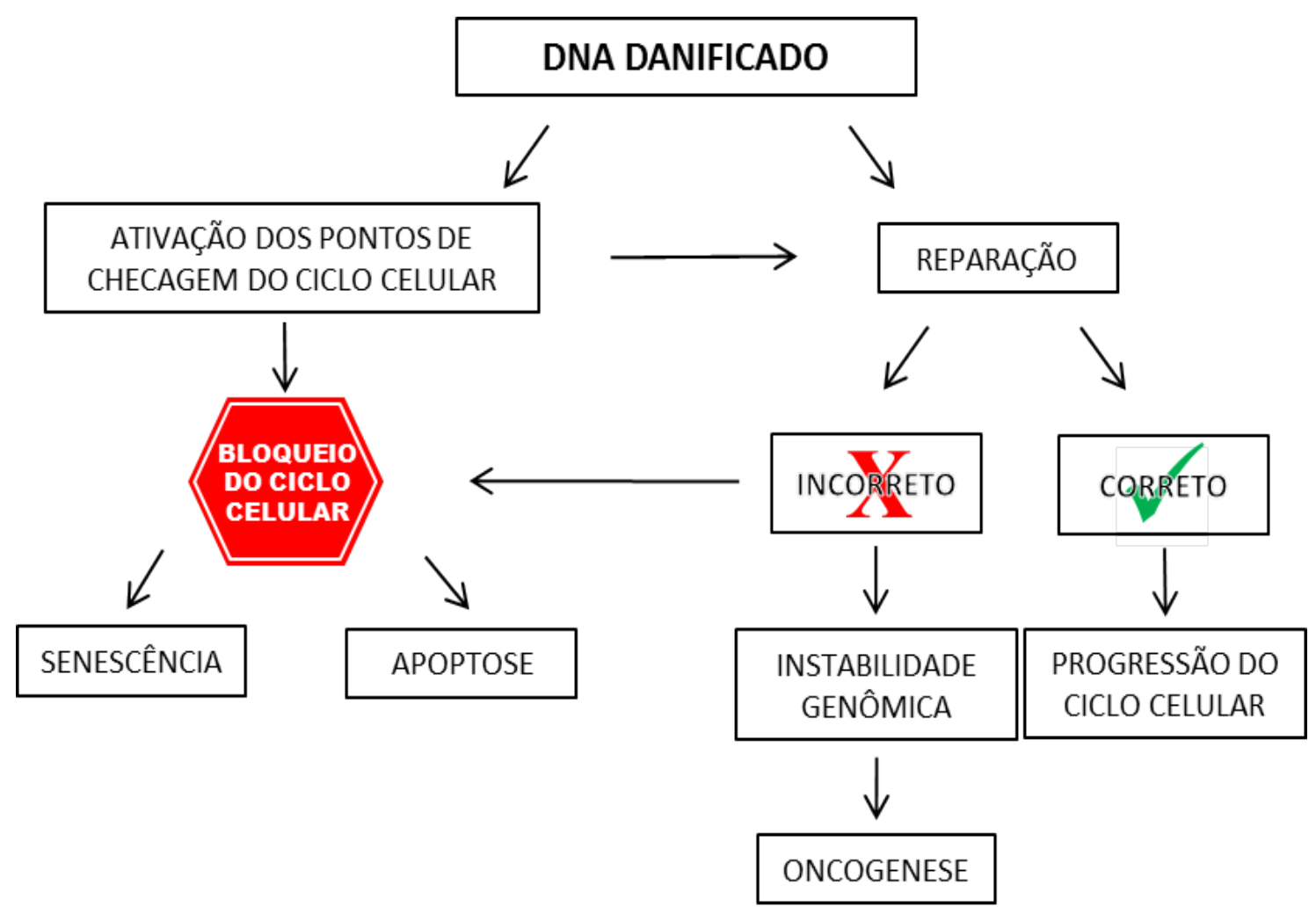

Figura 1| Resposta celular aos danos no DNA. O DNA celular danificado pode ser reparado nos pontos de checagem, bloqueando assim o ciclo celular ou levando a um estado de repouso. Se o dano não pôde ser reparado, o ciclo celular pode ser bloqueado de forma permanente, levando a célula a um estado senescente ou induzindo a apoptose. Se os danos forem corrigidos, a célula retorna ao ciclo celular. Entretanto, se essas avarias não forem notadas pela célula ou não forem corretamente reparadas, mutações e instabilidade genômica podem levar à oncogênese (adaptado de Houtgraaf et al., 2006).

O ciclo celular apresenta três pontos de checagem ou pontos de controle onde são checados se a célula possui todos os requisitos para prosseguir para a próxima etapa do ciclo celular. Dependendo da presença de algum dano, essa maquinaria de controle pode induzir uma parada entre as fases G1/S, intra-S ou entre as fases G2/M do ciclo celular (Figura 2). Caso o dano seja irreparável ou implique em um gasto metabólico muito alto, a célula inicia o processo de apoptose (Medema \& Macůrek, 2012; Gabrielli et al., 2012). 


\section{Ciclo celular e os pontos de checagem}

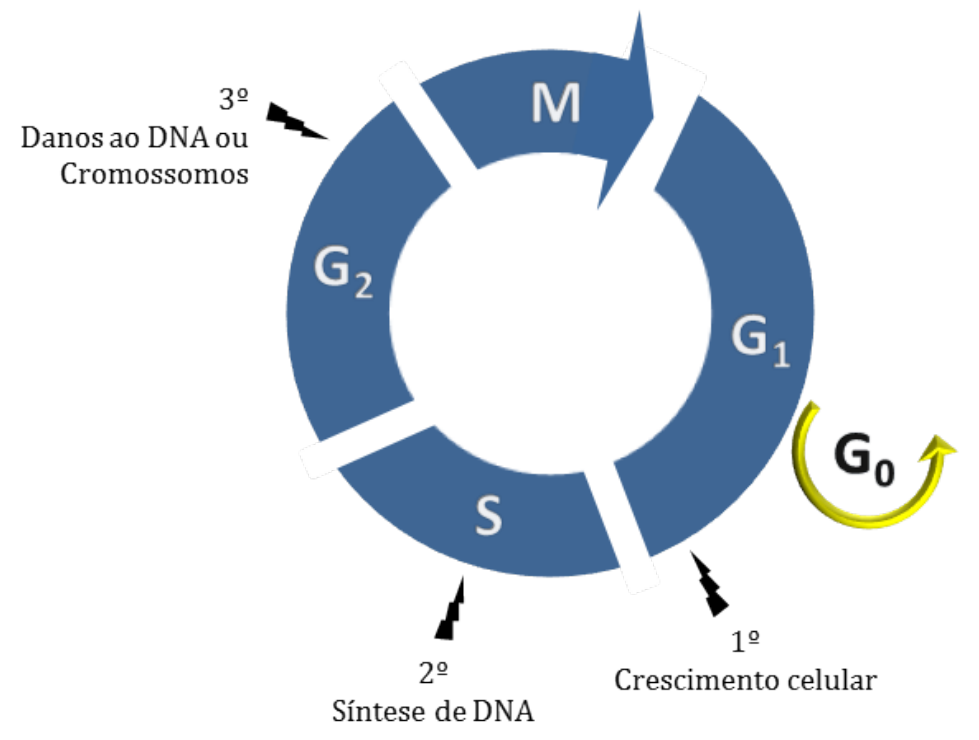

Figura 2| Ciclo celular e os pontos de checagem do DNA. A célula segue uma série de passos ordenados que controlam o seu desenvolvimento, sendo a progressão através dele regida tanto por fatores externos como internos. Os pontos de checagem do ciclo celular (apresentados como "setas" ordenadas de $1^{\circ}$ a $3^{\circ}$ ) regulam a complexa rede de interações que determinam o crescimento das células, a sua detenção no ciclo ou a apoptose.

\subsection{MORTE CELULAR}

Os processos de morte celular programada (MCP) e a resposta das células a danos no DNA são acontecimentos fundamentais para a manutenção da vida e estão intimamente ligados com a biologia de diversas doenças como o câncer.

Quando se fala em câncer, tradicionalmente surge a preocupação primária com a proliferação celular. No entanto, alterações na morte celular e resposta à danos são, se não mais, tão importantes quanto a proliferação descontrolada. Primeiro porque o dano ao DNA celular pode causar câncer. Isso é corroborado por diferentes estudos epidemiológicos a partir de modelos animais e da observação de síndromes de susceptibilidade humana ao câncer. Segundo porque o dano ao DNA pode ser usado para curar o câncer. A maioria das modalidades terapêuticas que são usadas atualmente para o tratamento de neoplasias tem como alvo o DNA, incluindo a terapia de radiação e muitos agentes quimioterapêuticos. E em terceiro lugar porque o dano ao DNA também é responsável pela maioria dos efeitos colaterais da terapia. A supressão da medula óssea, toxicidade gastrointestinal e perda dos 
cabelos são atribuídas à indução à morte celular das células progenitoras nestes tecidos (Kastan \& Bartek, 2004).

Conhecendo os diferentes mecanismos que podem conduzir à morte celular, e examinando cuidadosamente esses eventos, é possível caracterizar melhor a ativação de novas vias e aumentar nossa compreensão sobre patologias e sobre uma grande variedade de problemas relacionados à saúde humana.

\subsubsection{Apoptose}

A apoptose é um tipo de MCP, conhecido como MCP do tipo I ou MCP I. O conceito de apoptose foi proposto há 43 anos por Kerr e colaboradores (1972) e é descrito como um fenômeno ativo, altamente ordenado, ao ponto de ser chamado de morte programada. Trata-se de um fenômeno necessário e fundamental para o desenvolvimento e a manutenção da integridade de um organismo, tão complexo quanto a divisão ou a diferenciação celular e tem como finalidade a destruição das células com danos não reparados no material genético (Kerr et al., 1972; L Galluzzi et al., 2012).

A apoptose depende tanto de proteínas pré-existentes como da síntese de novo de algumas delas. 0 desencadeamento da apoptose é coordenado tanto no desenvolvimento embrionário e na renovação tecidual como na resposta patológica a lesões celulares (ruptura do DNA) ou a infecções por patógenos, ou seja, situações que representam ameaças à integridade do organismo. Além disso, a apoptose, ou mais precisamente a falha neste mecanismo, também desempenha um papel importante na patogênese de tumores, uma vez que permite às células neoplásicas, bem como às células geneticamente instáveis, sobreviverem indefinidamente (Siegel et al., 2014; Fleischer et al., 2006).

A transdução de sinal molecular relacionada ao processo de apoptose envolve a participação de diversas proteínas. As caspases, uma família de proteases específicas para cisteínas desempenha um papel central na maquinaria de morte celular. São pró-enzimas de cadeia simples (entre 30 e $50 \mathrm{kDa}$ ) sintetizadas como zimogênios inativos que são clivados em sítio específico levando à formação da forma ativa da enzima. Uma vez ativadas, as caspases degradam o DNA e genes housekeeping, envolvidos na manutenção do material genético, de maneira sistemática e hierárquica, resultando na perda irreversível da viabilidade celular. 
Em mamíferos, a família de caspases consiste em 14 proteínas, porém nem todas estão envolvidas com o processo apoptótico (Mita \& Tolcher, 2005).

As caspases envolvidas na apoptose podem ser ainda divididas em dois subgrupos funcionais com base nas suas funções conhecidas ou hipotéticas no processo: iniciador da caspase (caspase-2, -8, -9 e -10) e as caspases efetoras (caspase-3, -6 e -7). As caspases iniciadoras possuem motivos de interação proteína-proteína e, geralmente, uma vez ativadas, irão ativar as caspases efetoras. As caspases efetoras clivam substratos, tais como poli(ADP-ribose), polimerase (PARP) e outras proteínas, conduzindo a alterações morfológicas e bioquímicas características da apoptose (Cohen 1997). As funções das caspases podem então ser resumidas como: (1) parar o ciclo celular e inativar a reparação do DNA, (2) inativar o inibidor de apoptose (XIAP), e (3) desmontar o citoesqueleto celular (Z.-B. Wang et al., 2005).

Dependendo do estímulo inicial, diferentes vias podem ser deflagradas. A via intrínseca ou mitocondrial depende da permeabilização da membrana mitocondrial externa (MOMP) e liberação de citocromo C, que quando liberado, se liga a desoxiATP e ao fator ativador da peptidase apoptótica 1 (APAF1), formando o apoptosomo. Uma vez formado, o apoptosomo pode recrutar e ativar pró-caspase 9, uma caspase iniciadora que ativa outras caspases como caspase 3, 6 e 7 levando à apoptose (P. Li et al., 1997).

O segundo mecanismos pelo qual a apoptose pode ser deflagrada é conhecido como via extrínseca ou mediada por receptores de morte. Ela é ativada em resposta ao acoplamento de ligantes específicos aos receptores de morte presentes na superfície celular. A maioria dos receptores da morte já identificados são membros da superfamília de receptores para o fator de necrose tumoral (TNF) e são caracterizados por apresentar porção extracelular rica em cisteína e uma região citoplasmática, chamada cadeia da morte (death domain), essencial para transdução intracelular do sinal de morte (Atsumi et al., 1998; Vermeulen et al., 2003).

Após a associação do ligante com o receptor, este passa por uma mudança conformacional. Em seguida, uma molécula adaptadora, domínio de morte associado a Fas (FADD) ou domínio de morte associado ao receptor TNF (TNFADD) é recrutada, juntamente com pró-caspase 8 , formando o complexo sinalizador indutor 
de morte (DISC) (Z.-B. Wang et al., 2005). A ativação da caspase-8 em DISC, leva à ativação direta da caspase 3 conduzindo à morte celular (Z.-B. Wang et al., 2005).

\subsubsection{Autofagia}

Macroautofagia é caracterizada pelo acúmulo de conteúdo citoplasmático dentro de autofagossomos para a posterior degradação pelos lisossomos. 0 objetivo dessa maquinaria é a recuperação de fontes de energia e metabólitos necessários, caso haja privação de alimento. Também, a autofagia pode funcionar marcando organelas defeituosas ou desnecessárias para serem removidas. Quando a autofagia é induzida, uma membrana dupla se forma ao redor de uma porção de citoplasma, resultando na formação de uma estrutura denominada autofagossomo. Os autofagossomos então se fundem aos lisossomos dando origem aos autofagolisossomos (Green \& Levine, 2014).

Embora alguns autores se refiram à morte autofágica ou MCP II apenas como a morte com presença de autofagia, o termo tem sido também usado no sentido que a autofagia pode de fato levar à morte celular em alguns casos. Se a morte autofágica é uma morte celular que ocorre por autofagia ou com autofagia, essa questão ainda não pode ser respondida definitivamente. Embora existam muitos exemplos de

morte celular com autofagia, existem outros argumentos para sugerir que a autofagia tem, sobretudo, um papel na proteção de células (revisado em Kroemer \& Levine, 2008).

De acordo com as recomendações de nomenclatura do comitê de morte celular (L Galluzzi et al., 2012), aconselha-se investigar possíveis casos de morte celular autofágica com pelo menos duas proteínas autofágicas essenciais distintas. Além disso, casos de morte celular que exibem marcadores de autofagia como a lipidação de proteína associada a microtúbulos 1 cadeia leve 3 (LC3) ou um aumento da degradação de substratos autofágicos como sequestossoma 1 (SQSTM1), mas não são bloqueados por inibição da autofagia, não devem ser classificados como morte celular autofágica.

\subsubsection{Necrose}

A necrose é descrita como um evento passivo, não apoptótico, e definida como uma forma de morte celular acidental ou patológica, resultado de perturbações químicas ou físicas que culminam na liberação de conteúdo celular, e 
uma forte resposta inflamatória (Zong \& Thompson, 2006). Entretanto, recentemente tem se tornado cada vez mais claro que a necrose pode ocorrer de maneira programada, sendo nestes casos chamada de necroptose ou MCP III e sendo assim, dependente de uma extensa relação entre eventos bioquímicos e moleculares (Galluzzi \& Kroemer, 2008).

Diversos mediadores, organelas e processos celulares têm se mostrado envolvidos na MCP III. Sabe-se que na presença de inibidores de caspases e depleção de outras proteínas apoptóticas (cIAPs), o receptor 1 do fator de necrose tumoral (TNF) desencadeia uma sinalização que culmina na ligação de uma proteína quinase de interação com o receptor 3 (RIPK3) com seu ativador, a proteína quinase de interação com o receptor 1 (RIPK1) através do motivo RIP de interação homotípica (RHIM) (Moriwaki \& Chan 2013). A fosforilação de RIPK1 e RIPK3 estabiliza este complexo e promove a sua conversão a uma estrutura filamentosa do tipo amiloide chamada de necrosomo (J. Li et al. 2012). Uma vez ativada, RIPK3 recruta seu substrato, a proteína domínio quinase de linhagem mista (MLKL) (L. Sun et al. 2012), que fosforilada forma oligômeros que translocam às membranas intracelulares plasmáticas, as quais eventualmente levam à ruptura da membrana (Dondelinger et al., 2014).

A necrose é caracterizada morfologicamente por vacuolização do citoplasma, desagregação da membrana de plasma e uma indução de inflamação em torno da célula devido à libertação de conteúdos celulares e moléculas pró-inflamatórias, mas não à condensação da cromatina e fragmentação de DNA apresentada em células apoptóticas. A figura 3 ilustra as diferenças morfológicas características entre células morrendo por apoptose, necrose e autofagia. Como é possível notar, a catástrofe bioenergética que culmina em necrose também estimula a autofagia. Assim, vacuolização do citoplasma é observada tanto em células autofágicas (b) quanto e em células estimuladas para sofrer necroptose (d). Em contraste, os níveis de ATP são mantidos em células normais (a) e (c) apoptóticas consistentes com o número limitado de vacúolos autophagic no seu citoplasma (Edinger \& Thompson, 2004). 


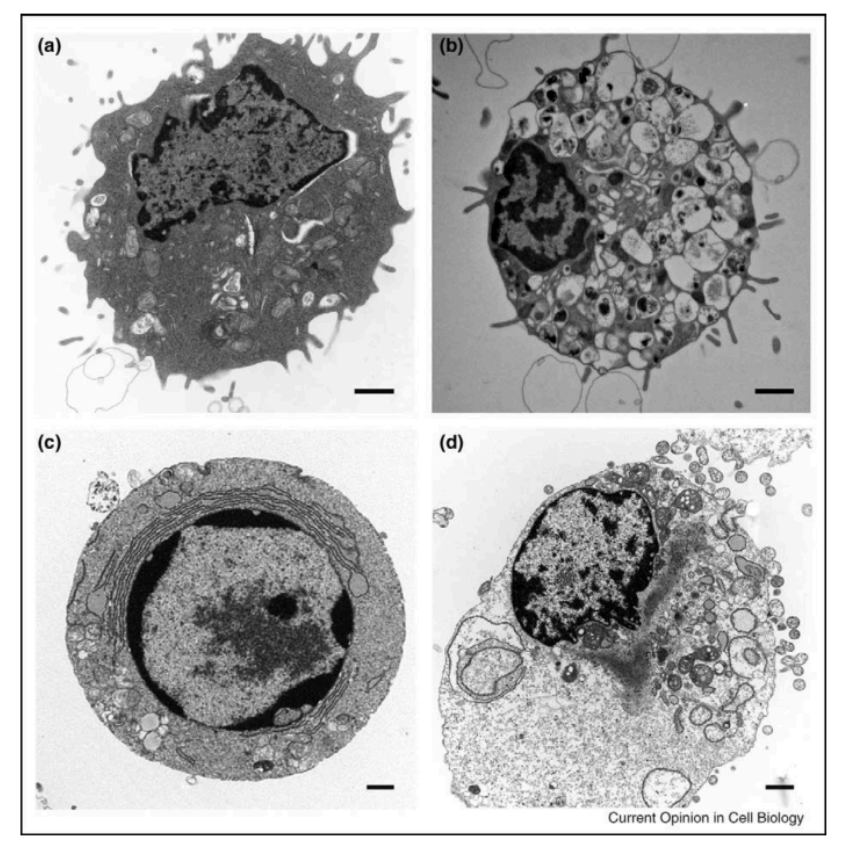

Figura 3| Características morfológicas de uma célula normal, autofágica, apoptótica e necrótica. (a) célula normal, (b) autofágica, (c) apoptótica (d) necrótica. As características morfológicas de apoptose são bem definidas, enquanto a distinção entre a morte necrótica e autofágica é menos clara. A barra de escala representa $1 \mu \mathrm{m}$ (Edinger \& Thompson, 2004).

\subsubsection{Anoikis}

A sobrevivência de células aderentes comprovadamente depende de sinais emitidos por integrinas e alguns receptores para fatores de crescimento como EGFR e sua interação com a matriz extracelular (Reginato et al. 2003). Anoikis descreve um tipo de resposta apoptótica de células aderentes desencadeada devido à perda de interação com a matriz extracelular. Esse termo foi cunhado em 1994 por Frisch e Francis, vem do Grego e significa, "o estado de estar desabrigado" (S M Frisch \& Francis, 1994). Como a resistência de células à anoikis está diretamente relacionada à invasividade e potencial metastático de tumores, tem-se feito um grande esforço na tentativa de caracterizar as cascatas moleculares envolvidas neste processo.

Com base nas características funcionais e bioquímicas, anoikis pode ser atualmente definida como uma cascata letal restrita a células aderentes iniciada pela perda de adesão à matriz extracelular e que é caracterizada por: 1- falta de acoplamento com a integrina $\beta 1$; 2 - regulação negativa da expressão de EGFR; 3inibição sinalização da quinase regulada por sinal extracelular 1 (ERK1 ); e 4- a superexpressão de Bcl-2 que interage mediador de morte celular (BIM) (Mailleux et al., 2007; Reginato et al., 2003). Todavia, é importante notar que na maioria, se não em todos os casos, o programa de morte celular desencadeado pela anoikis é 
executado pela maquinaria molecular para apoptose intrínseca (Reginato et al., 2003).

\subsection{QUE É O CÂNCER}

Segundo a OMS (World Health Organization 2013), o câncer pode ser definido como um conjunto de doenças que têm em comum o crescimento descontrolado de células que podem se disseminar para praticamente qualquer parte do corpo e invadir tecidos circundantes ou migrar para locais distantes do original em um processo conhecido como metástase. Sua ocorrência deriva de diversos fatores externos como tabaco, organismos infecciosos, químicos e radiações ou de fatores internos como as mutações herdadas, hormônios, condições imunológicas e mutações que ocorrem a partir do metabolismo, podendo esses fatores agir em conjunto ou em sequência para iniciar ou promover a carcinogênese (Siegel et al., 2014).

Atualmente existem mais de 100 tipos de câncer, sendo uma patologia responsável por altos índices de mortalidade e morbidade em todo mundo. Em 2008, foram estimados 12,7 milhões de novos casos e 7,6 milhões de mortes em decorrência de algum tipo de câncer. Em 2012 foram 8,2 milhões e segundo a OMS, a situação deve ficar ainda pior. A previsão é de que no ano 2030 o número de novos casos cresça para mais de 21 milhões de pessoas acometidas por essa doença, culminando em aproximadamente 13 milhões de mortes. Além disso, 60 a 70\% desses casos devem ocorrer em países de baixa e média renda (Ferlay et al., 2010; World Health organization, 2014).

\subsection{COMO UM CÂNCER SE INICIA? - CARCINOGÊNESE}

Como já foi citado, o crescimento normal de um tecido ocorre devido a um balanço delicado entre reguladores de vias pró e antiapoptóticas que controlam o metabolismo celular. A manutenção das taxa de proliferação e destruição das células, ou seja, de mitose e apoptose é o que garante a homeostasia tecidual. 0 processo de carcinogênese se inicia quando este equilíbrio é alterado em favor do prolongamento da sobrevida celular, situação que pode acontecer após uma série de 
alterações moleculares que fazem com que a célula adquira o fenótipo maligno (Denmeade \& Isaacs, 1996; Medema \& Macůrek, 2012).

Hanahan e Weinberg (2000) propuseram que, para que células normais evoluam progressivamente para um estado neoplásico, elas precisam adquirir uma sucessão dessas capacidades ou habilidades, que lhes permitam tornar-se tumorigênicas e, finalmente, malignas. São elas: (1) Crescimento mesmo na ausência de sinais de indução. Ou seja, as células continuam a se dividir em situações nas quais células normais aguardariam por uma sinalização química. (2) Crescimento apesar dos comandos de "pare". Em células normais, a compressão feita pelo crescimento de células adjacentes leva à emissão de sinais indicando a falta de espaço, todavia, esses sinais não afetam células tumorais. (3) Evasão de mecanismos de morte celular programada. Em células saudáveis, um dano genético em um nível crítico, ativa os mecanismos apoptóticos, todavia, as células cancerígenas ignoram esses comandos. (4) Habilidade para estimular a angiogênese. Como os tumores necessitam de oxigênio e nutrientes para sobreviver, eles estimulam a formação de novos vasos sanguíneos. (5) Imortalidade. Uma cultura de células humanas normais para de se dividir após 50 a 70 gerações, enquanto as células malignas agem manipulando seus telômeros, forçando esse limite reprodutivo. (6) Habilidade de invadir um tecido próximo ou produzir metástase se espalhando por outros órgãos, o que dá ao câncer seu caráter letal.

Em uma revisão da literatura mais recente, Douglas Hanahan e Weinberg (2011) adicionaram a esses marcadores mais duas características de ativação e duas características emergentes, consideradas importantes para o processo tumoral. Características de ativação são aquelas que permitem a aquisição das capacidades já citadas. São elas, a instabilidade do genoma, que gera a diversidade genética e acelera a aquisição de outras características, e a inflamação, que promove um estado inflamatório das lesões pré-malignas e malignas acionando células do sistema imunitário, algumas das quais servem para promover a progressão tumoral. Já as características emergentes adicionadas incluem a reprogramação do metabolismo energético e a evasão do sistema imune. Além de células tumorais, tumores exibem uma outra dimensão de complexidade denominado "microambiente do tumor" que incluem um repertório de células recrutadas, aparentemente normais que 
contribuem para a aquisição das características já apresentadas. Esse conceitos afetam cada vez mais o desenvolvimento de novos meios para compreender e tratar o câncer.

Sendo assim, o conceito de tumor ou neoplasia deixa de ser apenas uma massa de tecido formado por células anormais (tumorais), que pode se tornar maligno quando adquire a capacidade de invadir tecidos vizinhos em um processo conhecido como metástase (Rádis-Baptista 2005), para serem tecidos complexos constituídos por vários tipos de células diferentes que participam de múltiplas interações heterotípicas (Hanahan \& Weinberg, 2011).

A patogênese do câncer pode ser resumida em três etapas distintas, ilustradas na figura 4, e conhecidas como: iniciação (em que o agente cancerígeno induz mutações no DNA de células normais), seguida por promoção (na qual células mutadas desenvolvem vantagens de crescimento sobre as vizinhas, produzindo uma lesão característica e resultando na formação do tumor benigno), e progressão (em que os tumores se convertem em malignos e se tornam cada vez mais agressivos através da acumulação de alterações genéticas e epigenéticas complementares) (Boyle \& Levin, 2008).

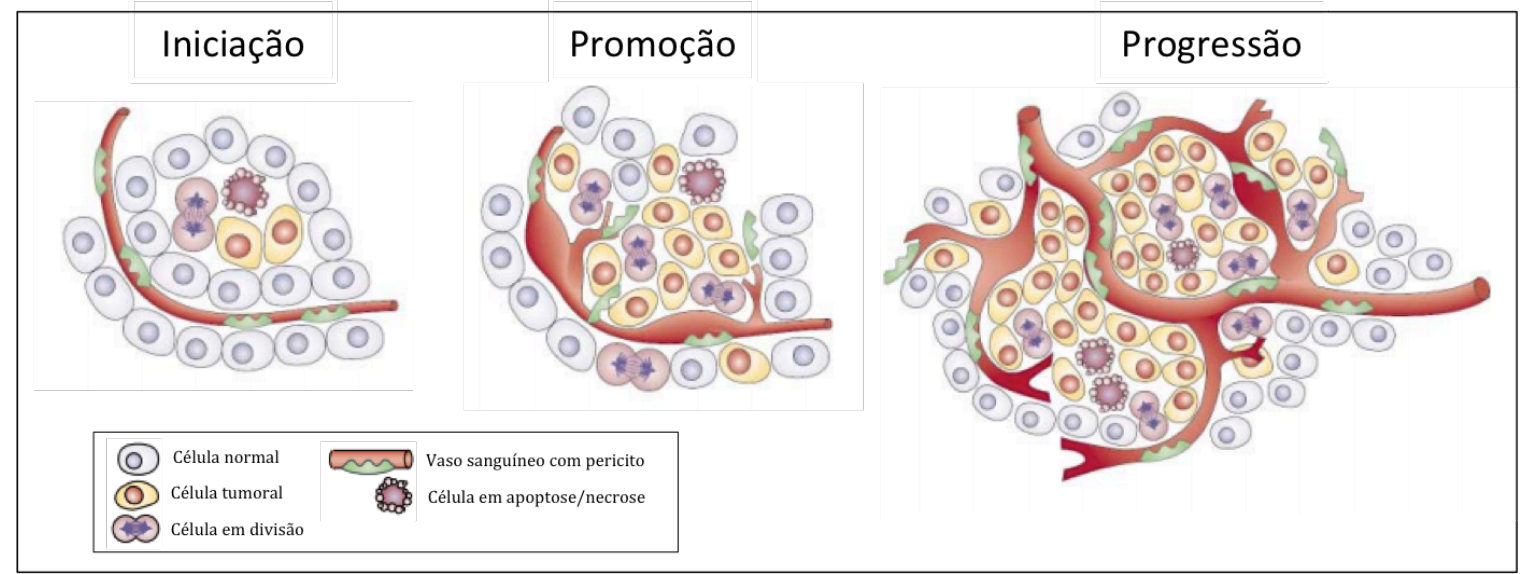

Figura 4| Etapas da patogênese tumoral e seu microambiente. Na fase inicial, as células sofrem mudanças no tamanho e forma dos núcleos, bem como um aumento expressivo devido à desregulação entre mitose e apoptose. Durante a promoção, o chamado "tumor benigno" produz uma lesão característica no tecido, ocorre a formação e maturação de novos vasos, bem como o recrutamento de células perivasculares. Nos casos mais graves ocorre a progressão, onde o tumor se torna invasivo ou metastático (imagem modificada de Bergers \& Benjamin, 2003). 
Os diversos tipos de cânceres existentes podem ser classificados de acordo com sua origem. $\mathrm{O}$ carcinoma começa na pele ou nos tecidos que revestem os órgãos internos. O sarcoma é um tumor que começa nos ossos, músculos, cartilagem, gordura, vasos sanguíneos ou no tecido conjuntivo. A leucemia é o câncer que começa nos tecidos hematopoiéticos, como a medula óssea, e faz com que um grande número de células anormais passem a ser produzidas e entrem na corrente sanguínea. O linfoma ou mieloma múltiplo são tumores que se iniciam nas células do sistema imunológico (Boyle \& Levin, 2008).

\subsection{CÂNCER CERVICAL}

No mundo todo, os cinco tipos de câncer que mais matam os homens são os de pulmão, estômago, fígado, cólon e esôfago. Já os que mais matam mulheres são os de mama, colo do útero (cervical), pulmão, colo-retal e de estômago, sendo que o câncer de mama e o cervical juntos representam 33\% dos novos casos de câncer em mulheres e $25 \%$ destes resultam em mortes. Apesar do câncer de mama ser em geral o mais frequente, em muitos países em desenvolvimento, o câncer cervical apresenta maior incidência devido a fatores culturais e socioeconômicos (Ferlay et al., 2010).

O câncer cervical é uma das causas mais comuns de mortalidade entre mulheres sexualmente ativas no mundo. Ele é causado pelo papilomavírus humano (HPV) e sua ocorrência manifesta-se a partir de 20 a 29 anos e o risco aumenta rapidamente entre 50 e 60 anos. Quase todas as pessoas sexualmente ativas serão infectadas pelo HPV em algum momento de suas vidas e alguns podem ser repetidamente infectados (World Health Organization, 2013).

Existem hoje 13 tipos de HPV reconhecidos como oncogênicos pela Agência Internacional para Pesquisa sobre o Câncer (IARC), sendo que os causados pelos tipos HPV 16 e 18 são os mais comuns. A maioria dessas infecções não causam sintomas ou doenças, desaparecendo espontaneamente. Todavia, infecções persistentes com tipos específicos de HPV (frequentemente os tipos 16 e 18) podem levar a lesões pré-cancerosas e se não forem tratadas adequadamente, podem evoluir para um câncer cervical. Alguns fatores ainda não muito claros contribuem para a regressão ou persistência da infecção e progressão das lesões precursoras e do câncer. Dentre eles estão aspectos relacionados à própria infecção pelo vírus como o tipo e carga viral, infecção única ou múltipla, além de fatores ligados à 
imunidade, genética e ao comportamento sexual. A idade também parece interferir nesse processo, uma vez que, a maioria das infecções em mulheres com menos de 30 anos regride espontaneamente, ao passo que, acima dessa idade, a persistência é mais frequente. 0 tabagismo também é um dos fatores que eleva o risco para o desenvolvimento do câncer do colo do útero (Instituto Nacional de Câncer José Alencar Gomes da Silva, 2014).

A vacina é uma promissora ferramenta para o controle desse tipo de câncer, porém ainda é uma prática distante da realidade dos países de baixa e média renda, em razão de seu alto custo. Além disso, estão registradas apenas vacinas quadrivalentes, que conferem imunidade aos tipos HPV 6, 11, 16 e 18 e bivalente que confere imunidade aos tipos HPV 16 e 18, não tendo sido registradas ainda vacinas contra os outros tipos de vírus (Parkin et al., 1999).

Em geral, a razão mortalidade/incidência é de 52\%, o que representou 275 mil óbitos em 2008, sendo que mais de 88\% desses óbitos ocorrem em países em desenvolvimento. Somente na Índia, que é o segundo país mais populoso do mundo, foram relatados cerca de $27 \%$ dos óbitos por esse tipo de câncer. Cinquenta e três mil casos ocorreram na África, 31.400 na América Latina e Caribe e 159.800 na Ásia (Boyle \& Levin, 2008; Ferlay et al., 2010). No Brasil, segundo a estimativa do INCA, em 2014 eram esperados 15.590 novos casos, com um risco estimado de 15,33 casos a cada 100 mil mulheres. Sem considerar os tumores de pele não melanoma, o câncer do colo do útero é o mais incidente na região Norte (23,57/ 100 mil). Nas regiões Centro-Oeste (22,19/ 100 mil) e Nordeste (18,79/ 100 mil), é o segundo mais frequente. Na região Sudeste $(10,15 / 100$ mil), o quarto e, na região Sul (15,87 /100 mil), o quinto mais frequente (Instituto Nacional de Câncer José Alencar Gomes da Silva, 2014).

\subsection{POTENCIAL BIOTECNOLÓGICO DAS PEÇONHAS DE SERPENTES}

As peçonhas de serpentes são conhecidas por apresentarem diversas ações biológicas: proteólise, coagulação, hemorragia, neurotoxicidade e miotoxidade. Envenenamentos provocados por serpentes do gênero Caudisona, popularmente conhecidas como cascavéis, provocam mal-estar, náuseas, cefaleia, prostração e sonolência. No local da picada ocorre edema discreto e parestesia (perda de sensibilidade), além dos sintomas envolvendo ações neurológicas e miotóxicas como facies miastênica, oftalmoplegia, dificuldade de acomodação 
visual, mioglobinúria e elevação dos níveis séricos de creatina-quinase, o que pode levar à morte por insuficiência renal (Azevedo-Marques et al., 2003).

Já os envenenamentos provocados pelos gêneros Bothrops, Bothriopsis e Bothrocophias causam edema, equimose, dor, hemorragia e mionecrose, associados a alterações sistêmicas como distúrbios cardiovasculares e hemodinâmicos, além das lesões renais (Brasil, 2001).

Apesar dos efeitos tóxicos acima descritos, as peçonhas em geral constituem uma rica fonte de moléculas com importantes propriedades farmacológicas e que possuem um grande potencial para a produção e desenho de novos medicamentos (Fox \& Serrano, 2007; King, 2011; McCleary \& Kini, 2013).

Os peptídeos potencializadores de bradicinina (BPPs), por exemplo, foram descobertos a partir da peçonha de B. jararaca e estão associados ao controle da pressão sanguínea e a muitos outros processos fisiopatológicos. Os BPPs são peptídeos ricos em resíduos de prolina que possuem um ácido piroglutâmico na porção N-terminal, geralmente uma sequência Ile-Pro-Pro na porção C-terminal e pertencem a uma classe de inibidores naturais da enzima conversora de angiotensina I (ECA I) e angiotensina II (ECA II) (Ferreira, 1965; Ferreira et al., 1970; 1998).

O trabalho com tais moléculas isoladas da peçonha de B. jararaca, iniciado em 1965 por Sérgio Ferreira e colaboradores, levou ao surgimento de outros estudos como o que e permitiu o desenho de outros inibidores da ECA (Cushman et al., 1977) e posteriormente ao desenvolvimento do Captopril ${ }^{\circledR}$, o primeiro inibidor do sítio ativo da ECA e a droga mais utilizada no tratamento da hipertensão até hoje.

Atualmente, além dos BPPs, pesquisas demonstram uma grande diversidade funcional e estrutural de componentes bioativos (Gutiérrez 2002), com várias aplicações biotecnológicas, tais como: analgésicos (Mancin et al. 1998; Cury \& Picolo 2006), antiinflamatórios ( Nunes et al., 2007; Hernández Cruz et al., 2008), antimicrobianos ( Nair et al., 2007; Aragão, 2008; Bustillo et al., 2008; Oguiura \& Boni-Mitake, 2011), antitumorais (Gebrim et al., 2009; Rodrigues et al., 2009; Bazaa et al., 2009). 


\subsection{TOXINAS ISOLADAS DE SERPENTES ATIVAS CONTRA O CÂNCER}

Alguns componentes isolados das peçonhas de serpentes podem apresentar atividade citotóxica (apoptótica ou necrótica), exercer atividade sobre a adesão celular ou ainda interferir no processo de angiogênese, atividades que podem contribuir para a destruição ou redução de um tumor, tornando-se bons candidatos para serem utilizados como antitumorais. As fosfolipases do tipo A2 (PLA2), desintegrinas, lectinas e metaloproteases são algumas das principais moléculas com tais atividades já descritas (Moura-da-Silva, 1996; Black et al., 1997; de Carvalho et al., 2001; Moura-da-Silva et al., 2003; Gebrim et al., 2009; Rodrigues et al., 2009)

Substâncias com a capacidade de se ligar a integrinas e interferir na adesão celular formam uma dessas famílias de moléculas promissoras no uso contra tumores. Por exemplo, algumas integrinas expressas em membranas de plaquetas são alvos de várias toxinas de serpentes que inibem ou promovem a agregação plaquetária (Andrews \& Berndt, 2000; Andrews \& Kamiguti, 2001; Andrews et al., 2002). Dentre as toxinas mais envolvidas nesses processos estão as famílias de desintegrinas, lectinas do tipo-C e metaloproteases como a agretina de Calloselasma rhodostoma (Chung et al., 2001); bilinexina de Agkistrodon bilineatus (Du et al., 2001); crovidisina de Crotalus viridis (C.-Z. Liu \& Huang, 1997); EMS16 de Echis multisquamatus (Horii et al., 2003); jararagina de Bothrops jararaca (Deluca et al., 1995; Kamiguti et al., 1996); rhodocetina de Calloselasma rhodostoma (Wang et al., 1999), batroxostatina de Bothrops atrox (Rucinski et al., 1990) e bothrocetina de Bothrops jararaca (Fujimura et al., 1991).

As integrinas medeiam processos de sinalização que interferem em várias funções celulares como a adesão, migração celular, crescimento, sobrevivência, diferenciação, desenvolvimento, reparação tecidual, hemostasia e até mesmo apoptose (Srichai \& Zent, 2010). Os locais de contato entre as integrinas são regiões importantes para a transdução de sinal. Através de clusters de integrinas, ocorre o crescimento celular e migrações normais. Apesar da perda desse contato poder estimular o crescimento de células tumorais, bem como reforçar a capacidade de invasão das células tumorais, por outro lado, essa perda de contato também pode induzir apoptose in vitro (Schwartz \& Ingber, 1994).

As integrinas possuem a característica particular de estarem diferencialmente distribuídas nos tecidos humanos adultos. Por exemplo, algumas 
delas são diferentemente expressas em alguns tipos de tumores invasivos, correlacionando-se com a agressividade do câncer. Por isso, uma estratégia para reduzir a progressão do câncer seria a marcação de integrinas de células tumorais ou células endoteliais vasculares recrutadas (Rust et al., 2002).

Proteínas pertencentes à família das metaloproteases, lectinas do tipo-C e desintegrinas também têm sido objeto de diversos estudos, uma vez que podem inibir a migração celular in vitro, a adesão, o descolamento, a proliferação celular e a progressão do tumor in vivo interagindo especificamente com algumas integrinas nas membranas celulares (Kamiguti et al., 1998; Markland, 1998; de Carvalho et al., 2001).

Por exemplo, metaloproteases/desintegrinas, extraídas a partir da peçonha da cascavel Crotalus atrox, induzem a morte celular por apoptose in vitro de células endoteliais vasculares (Masuda et al., 1997; Masuda et al., 1998). A crovidisina, outra metaloprotease purificada a partir da peçonha de Crotalus viridis, provoca descolamento de células de osteosarcoma, mas não de osteoblastos cultivados a partir de proteínas da matriz extracelular. A proteólise de proteínas da matriz extracelular pela crovidisina implicou em descolamento seletivo (Tang et al., 2004).

As PLA2 isoladas de peçonhas de serpentes formam outro grupo de moléculas que têm sido amplamente estudadas. Trabalhos recentes propõem que a atividade citotóxica de algumas PLA2 sobre linhagens de células tumorais pode estar associada principalmente com a indução de apoptose, considerando que elas supostamente agem como mediadores de apoptose em vários modelos, incluindo diferentes linhagens celulares (Cummings, McHowat \& Schnellmann, 2000). Estudos indicam que a atividade fosfolipásica aumenta a movimentação de fosfolipídios, o que pode levar a mudanças em membranas durante o processo de morte celular programada (Panini et al., 2001).

As fosfolipases (PL) recebem, de maneira geral, diferentes designações em função do sítio de clivagem, podendo ser classificadas como do tipo $A_{1}, A_{2}, B, C$ e $D$, (Figura 5). Atualmente, a superfamília de PLA2s divide-se em 15 grupos e subgrupos e inclue 5 tipos distintos de enzimas de acordo com o trabalho de Schaloske \& Dennis (2006). São elas as PLA2 secretadas (sPLA2), as PLA2 citosólicas (cPLA2), as PLA2 $\mathrm{Ca}^{2+}$ independentes (iPLA2), as acetilhidrolases ativadoras do fator ativador de plaquetas (PAF-AH) e as PLA2s lisosomais (figura 6). 
As pequenas PLA2 secretadas que possuem entre 14 e $18 \mathrm{kDa}$, contêm entre 5 e 8 pontes dissulfeto, apresentam uma histidina no sítio de ação e requerem quantidades na faixa de $\mu \mathrm{M}$ de $\mathrm{Ca}^{2+}$ para sua atividade. Estas podem ser subdivididas nos grupos IA, IB, IIA, IIB, IIC, IID, IIE, IIF, III, IV, IX, X, XIA, XIB, XII, XIII e XIV Schaloske \& Dennis, 2006.

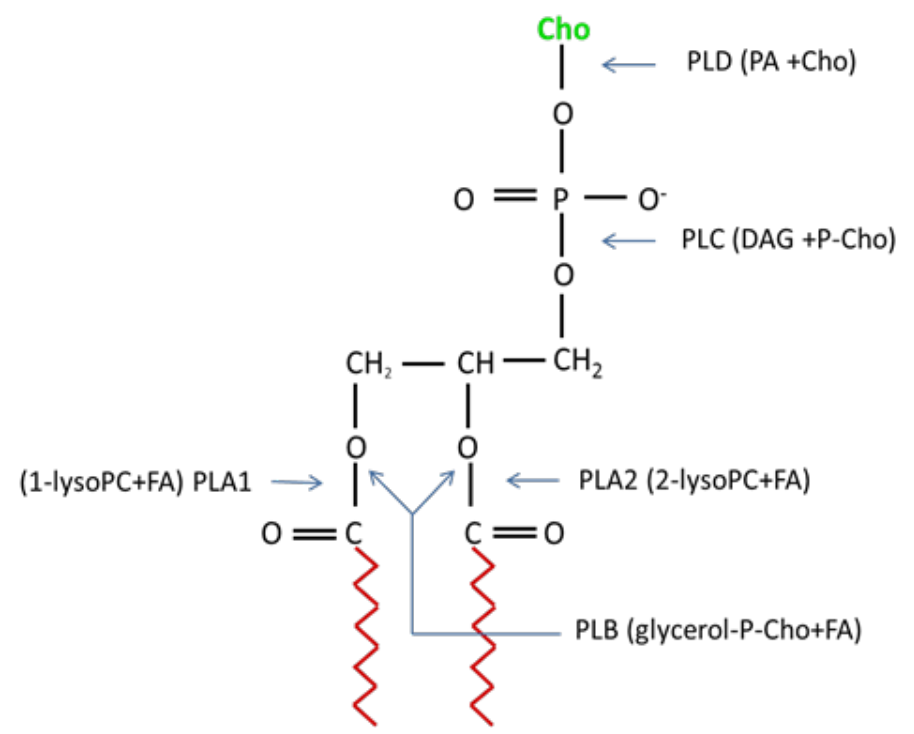

Figura 5| Hidrólise de fosfatidilcolina pela PLA1, PLA2, PLB, PLC e PLD e os respectivos produtos da reação (entre parênteses). Liberação de ácido graxo e lisofosfolipídeos pela hidrólise da ligação sn-2 do fosfolipídeo. Cho: colina, DAG: diacilglicerol, P-Cho: fosfocolina, FA: ácido graxo. Em vermelho, estão destacados os ácidos graxos e, em verde, o grupo polar colina associado ao fosfato (modificado de Paulo \& Aragão, 2005).

As PLA2 citosólicas possuem massa entre 61 e $114 \mathrm{kDa}$, apresentam uma serina no sítio catalítico e requerem $\mathrm{Ca}^{2+}$ para sua atividade. Elas podem ser subdivididas como dos tipos GIVA, GIVB, GIVC, GIVD, GIVE ou GIVF de acordo com similaridades na sequência de aminoácidos.

As cPLA2 são encontradas no citosol de plaquetas e monócitos, podem requerer quantidades baixas de $\mathrm{Ca}^{2+}$ para sua atividade e acredita-se que essas enzimas sejam ativadas por estímulos ligados à transdução de sinal (Clark et al. 1991). Além de sua atividade catalítica, elas exercem uma variedade de atividades enzimáticas auxiliares apresentando papel significativo no remodelamento de fosfolipídeos nas células, na isquemia do miocárdio (Hazen et al.,1991), na liberação 
do ácido araquidônico (Lehman et al., 1993; Ponzoni \& Cornaglia-Ferraris, 1993) e na secreção de insulina (Gross et al., 1993; Ramanadham et al., 1993).

Outro grupo chamado de GVI é formado por PLA2 $\mathrm{Ca}^{2+}$ independentes, que possuem uma serina no sítio catalítico, todavia não requerem $\mathrm{Ca}^{2+}$ para sua atividade. Elas podem ser subdivididas como GVIA, GVIB, GVIC, GVID, GVIE ou GVIF.

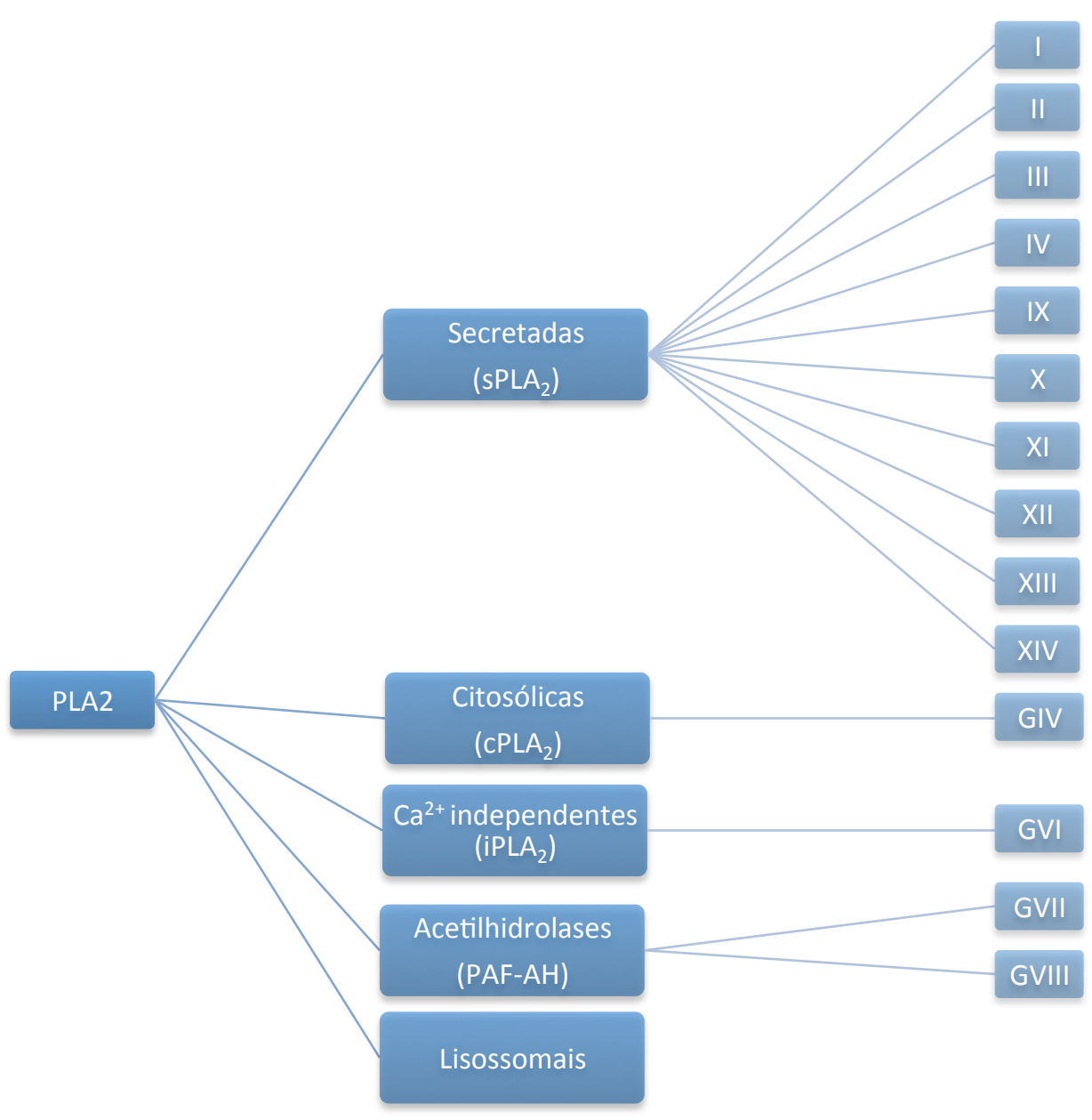

Figura 6| Classificação das PLA2 (compilado a partir de Schaloske \& Dennis, 2006).

Outras duas PLA2s que contêm serina são designadas GVII e GVIII. As enzimas destes grupos hidrolisam o grupo acetil na posição sn-2 do PAF (1-Oalkyl-2-acetyl-sn-glycero-3-phosphocholine), originalmente chamadas de acetilhidrolases PAF (PAF-AH). Uma dessas enzimas é secretada, a GVIIA. Esta enzima é também conhecida como PAF-AH plasmática ou PLA2 lipoproteína- 
associada (Lp-PLA2). As outras duas enzimas, GVIIB e GVIII, são enzimas intracelulares.

O último grupo é composto por uma enzima chamada de PLA2 lisosomal que foi recentemente purificada a partir de cérebro bovino. Essa enzima esterifica um grupo acil da hidroxila na posição C-1 da ceramida de fosfolipídeos utilizando como doador um grupo acila. Essa PLA2 foi primeiramente nomeada como O-sintase acylceramida (ACS) e sua atividade é independente de $\mathrm{Ca}^{2+}$ (Schaloske \& Dennis 2006a).

As PLA2 secretadas estão subdivididas em vários grupos baseando-se principalmente na estrutura primária. As enzimas presentes em peçonhas pertencem aos grupos I, II, III e IV ( Heinrikson et al., 1977; Davidson \& Dennis, 1990; Schaloske \& Dennis, 2006) e são melhor descritas abaixo:

- Grupo I: enzimas encontradas no pâncreas de mamíferos e na peçonha de serpentes das famílias Elapidae e Hidrophiidae. São constituídas por, aproximadamente, 115-120 resíduos de aminoácidos ligados por sete pontes dissulfídicas e são secretadas como zimogênios, manifestando sua atividade enzimática somente através da clivagem proteica e de forma limitada.

- Grupo II: enzimas com 120 a 125 resíduos de aminoácidos, encontradas em venenos de serpentes da família Viperidae e em células como plaquetas. Possuem uma cauda adicional na região C-terminal que forma uma ponte dissulfeto extra com um resíduo próximo ao sítio ativo His-48 (Heinrikson, Krueger, \& Keim 1977).

- Grupo III: é representado pelas PLA2 de peçonhas de abelhas e de lagartos pertencentes ao gênero Heloderma. Apresentam menor grau de similaridade em relação aos grupos I e II e tratam-se de glicoproteínas contendo de 130-135 resíduos de aminoácidos.

- Grupo IV: primeiramente foi isolada da peçonha de Conus magus. Essa proteína possui duas alças, uma longa e uma curta, contendo 77 e 42 resíduos, respectivamente, unidas por uma ou mais pontes dissulfeto (McIntosh et al. 1995).

As enzimas do grupo II despertam grande interesse por estarem envolvidas nos principais efeitos tóxicos observados nos envenenamentos ofídicos como a miotoxicidade, cardiotoxicidade, neurotoxicidade, inflamação, hipertensão, entre outros (M. Murakami \& Kudo 2002). 
Elas também podem ser classificadas em dois tipos de acordo com o resíduo presente na posição 49. As que contêm um aspartato (Asp-49) catalisam de maneira dependente de $\mathrm{Ca}^{+2}$ e atuam na hidrólise de fosfolipídeos de membranas celulares na porção sn-2, liberando ácido araquidônico e induzindo a síntese de mediadores inflamatórios como as prostaglandinas, leucotrienos e tromboxanos (Xingding et al., 2009). Já as que contêm uma lisina na posição 49 (Lys-49), também chamadas de PLA2-símile, possuem baixa ou nenhuma atividade catalítica. Todavia, independente de capacidade de hidrolisar ou não fosfolipídeos, ambas causam danos celulares e por isso as PLA2 Lys-49 têm atraído a atenção como modelos de indução de mionecrose por um mecanismo de ação cataliticamente independente (Polgár et al., 1996; Delatorre et al., 2010).

Como exemplo de enzimas Lys-49 que possuem pouca ou nenhuma atividade catalítica, porém apresentam atividade miotóxica intensa, podemos citar as PLA2 Lys-49 extraídas das peçonhas de Bothrops asper (MT-II), B. jararacussu (BTX-I), B. pirajai (PrTX-I), B. moojeni (MjTX-I) e B. pauloensis (BnSP-7) (A. Soares \& Giglio 2003).

Existem também algumas variantes da subclasse Lys49, como Arg49 e Ser49 presentes em algumas PLA2s de peçonhas ofídicas já isoladas. Chijiwa et al. (2006) isolaram duas PLA2s da peçonha de Protobothrops elegans que possuem uma Arg na posição 49 (Arg49) e que apresentam alto grau de homologia com as Lys49 já isoladas.

Possivelmente a ação miotóxica associada a estas enzimas deve-se à presença de resíduos hidrofóbicos e catiônicos próximos da região C-terminal (Calderón \& Lomonte 1998). O fato de apresentarem sítios farmacológicos específicos torna possível a inibição de alguns efeitos indesejados e ativação de sítios de interesse, transformando-as em moléculas bastante promissoras do ponto de vista farmacológico (Kini, 1997; Xingding et al., 2009).

As PLA2s isoladas das peçonhas de diversas serpentes também apresentam atividade citotóxica. As miotoxinas de B. brazili (MTX-I e II) apresentaram atividade citotóxica contra a linhagem tumoral Jurkat (Costa et al. 2008) e BmooTX-I mostrou-se tóxica sobre linhagens tumorais humanas e de camundongos, sendo menos citotóxica sobre linhagens de células normais (macrófagos) (Paulo \& Aragão 2005). As do grupo B. neuwiedi já mostraram atividade sobre linhagens B16F10 
(melanoma) e K-562 (leucemia), sendo ainda capazes de induzir a proliferação celular de HLL (fibroblastos) de forma dose dependente (Daniele et al., 1997; Ferreira et al., 2008). Todos esses estudos sugerem o emprego de PLA2s como potentes drogas anticâncer. Note que a terminologia "grupo B. neuwiedi" refere-se a um grande agrupamento do ponto de vista filogenético, contendo várias espécies descritas na revisão taxonômica realizada por Silva \& Rodrigues (2008), incluindo agora a nova espécie (B. marmoratus) que passa a fazer parte do grupo.

A perspectiva do desenvolvimento de um tratamento coadjuvante para o câncer a partir de toxinas de serpentes é promissor. Até agora, além da atividade individual dessas moléculas, sabe-se que a complexação de desintegrinas com lipossomos, melhora sua eficácia, meia-vida na circulação e facilita sua administração. Por exemplo, a liberação de contortrostatina, uma desintegrina isolada da peçonha de Agkistrodon contortrix contortrix em lipossomo, por meio da administração intravenosa, mantém a potente atividade antiangiogênica da toxina e impede a progressão do câncer de mama, como ficou demonstrado com um modelo de tumor mamário humano (Swenson et al. 2004).

As publicações sobre atividade antitumoral das toxinas de serpentes são, em sua maioria, descritiva, e ainda não existem modelos consistentes que expliquem esses efeitos. 0 que se tem até o momento são basicamente evidências das atividades farmacológicas in vitro. Existe a preocupação e a possibilidade que essas moléculas sejam inadequadas para uso imediato, porém é indiscutível que elas servem como base ou modelos para novos fármacos ou para compreender alguns processos biológicos e por isso possuem um grande potencial biotecnológico.

\subsection{A ESPÉCIE Bothrops marmoratus}

O grupo de serpentes antes classificadas como Bothrops neuwiedi (Amaral 1925), também conhecidas como jararacas-pintadas, representam a terceira espécie mais comum entre as jararacas no Brasil.

Recentemente, após revisão taxonômica realizada por Silva \& Rodrigues (2008) e reconhecida pela Sociedade Brasileira de Herpetologia (Bérnils \& Costa 2012), este grupo foi reclassificado em sete espécies distintas, encontradas em diferentes regiões de toda a América do Sul (Figura 7), sendo tais espécies designadas Bothrops pauloensis, B. mattogrossensis, B. pubescens, B. diporus, B. lutzi, 
B. neuwiedi e uma nova espécie denominada B. marmoratus, alvo do presente estudo.

A nova espécie Bothrops marmoratus mostrada na Figura 8, apresenta distribuição nos estados de Goiás, Tocantins e oeste de Minas Gerais, que coincide exatamente com a região de Cerrado do Brasil Central (V. X. da Silva \& Rodrigues 2008).

Os estudos realizados, sejam com dados morfológicos ou moleculares, demonstram que a compreensão das relações filogenéticas das espécies do grupo neuwiedi está apenas começando e reforça a necessidade de que mais estudos sejam desenvolvidos, a partir de dados bioquímicos, moleculares, osteológicos, anatômicos e ecológicos, como indicam trabalhos recentes realizados empregando-se abordagem multidisciplinar (Wüster, Duarte, \& Salomão, 2005; Sanders, Malhotra \& Thorpe, 2006; Fenwick Jr., Evans \& Parkinson, 2009).
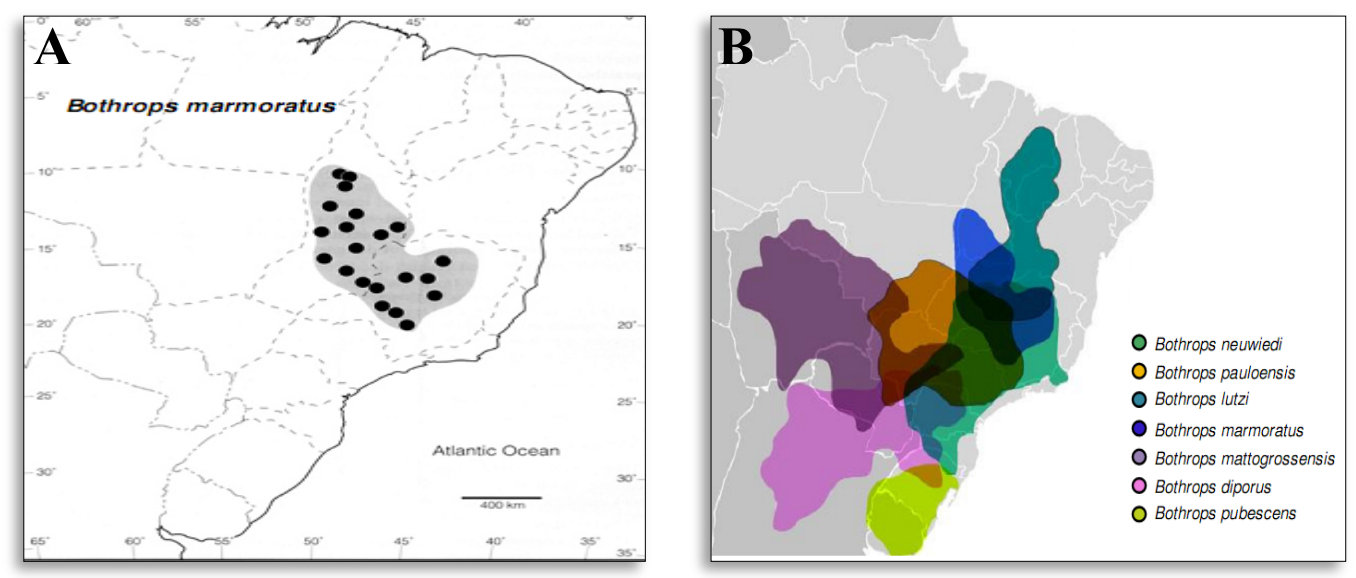

Figura 7| Mapas evidenciando (A) a distribuição geográfica da espécie B. marmoratus e (B) a sobreposição das distribuições geográficas das espécies do grupo $B$. neuwiedi compilado a partir de Silva \& Rodrigues, 2008 apud Machado, 2010.

A espécie B. marmoratus é caracterizada por escamas supralabiais pontilhadas, em vez das manchas bem evidentes, presentes nas demais espécies, uma discreta listra branca nas escamas pós-orbitais, mais difícil de ser notada, e de 15 a 27 manchas na região dorsolateral escuras margeadas de branco e com formato trapezoidal. Seu padrão de coloração, juntamente com as bordas difusas das manchas, conferem um aspecto marmóreo a esta serpente.

Os componentes da peçonha de serpentes pertencentes ao grupo $B$. neuwiedi ainda são pouco conhecidos comparando com outras serpentes do gênero 
botrópico. Além disso, devido às recentes mudanças de nomenclatura taxonômica ocorridas, muitas das toxinas descritas para a espécie B. neuwiedi devem ser reclassificadas, pois podem pertencer a espécies distintas. A tabela 1 mostra uma lista com algumas toxinas descritas, isoladas das peçonhas de serpentes do grupo $B$. neuwiedi.

As toxinas extraídas de venenos e peçonhas animais fascinam o homem há muito tempo devido a suas implicações farmacológicas. Com base nesses efeitos, laboratórios farmacêuticos do mundo todo têm utilizado essas toxinas como modelos para o desenvolvimento de novas drogas. As pesquisas no campo de toxinas contribuem muito para a compreensão dos mecanismos de ação e possíveis aplicações das novas moléculas encontradas e já serviram de protótipos para o desenvolvimento de algumas drogas disponíveis comercialmente.

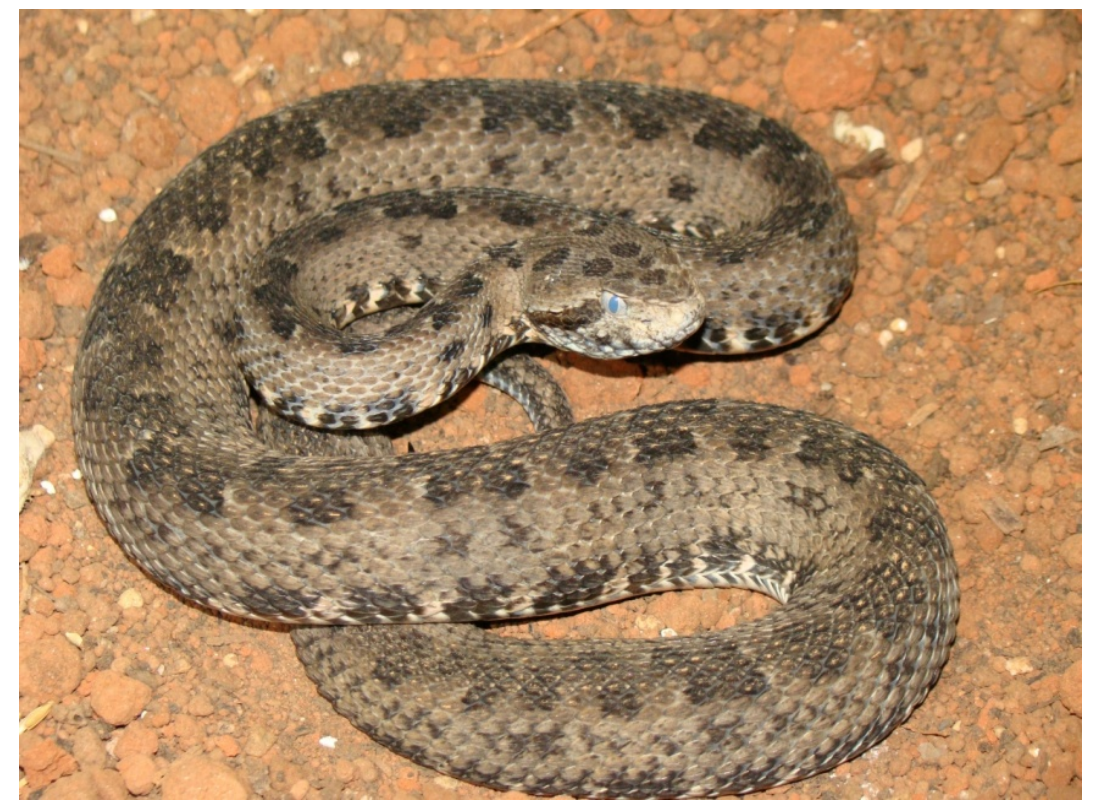

Figura 8| Bothrops marmoratus (Foto: Marco Antônio de Freitas).

Todavia, para que esse tipo de produto chegue ao consumidor, além das pesquisas com moléculas biologicamente ativas é preciso desenvolver o processo de formulação com vistas à produção em escala industrial e alcançar o processamento final, o que tem ocorrido muito pouco no Brasil. Nos últimos anos, as questões dos medicamentos vêm ganhando espaço na agenda governamental e na sociedade. Contudo, apesar dos medicamentos terem se tornado imprescindíveis para a sociedade e para o Estado, pouco da produção científica nacional tem sido aproveitada pelas empresas. 
Tabela 1| Lista de toxinas isoladas de serpentes do grupo neuwiedi.

\begin{tabular}{|c|c|c|c|c|}
\hline ESPÉCIE & TOXINA & Mr (kDa) & ATIVIDADE & REFERÊNCIA \\
\hline B. neuwiedi & PLA2 & $\mathrm{Nd}$ & $\begin{array}{l}\text { Inibidor da cadeia transportadora de } \\
\text { elétrons }\end{array}$ & Vidal et al., 1966 \\
\hline B. neuwiedi & $\begin{array}{c}\text { Metaloproteínas (NHFa } \\
\text { e NHFb) }\end{array}$ & 46 e 58 & Hemorrágica & $\begin{array}{l}\text { Mandelbaum et al., 1984; } \\
\quad \text { Queiroz et al., } 1985\end{array}$ \\
\hline B. neuwiedi & Proteína & 60 & Ativador de protrombina & $\begin{array}{c}\text { Govers-Riemslag et al., } \\
1987\end{array}$ \\
\hline B. neuwiedi & Metalloproteínas & $\mathrm{Nd}$ & Antigênica & $\begin{array}{l}\text { Mandelbaum \& Assakura, } \\
1988\end{array}$ \\
\hline B. neuwiedi & $\begin{array}{c}\text { Peptídeos } \\
\text { (BPP-II, BPP-III, and } \\
\text { BPP-V) }\end{array}$ & $\begin{array}{c}1.372 ; \\
1.046 \mathrm{e} \\
1.078\end{array}$ & Potencializador de bradicinina & Ferreira et al., 1998 \\
\hline B. neuwiedi & $P 1$ & 15 & PLA2, anticoagulante, edematogênico & Daniele et al., 1995 \\
\hline B. neuwiedi & $P 2$ & 16,2 & PLA2, anticoagulante & Daniele et al., 1995 \\
\hline B. neuwiedi & P3 & 15 & PLA2, citotóxico & Daniele et al., 1997 \\
\hline $\begin{array}{l}\text { B. neuwiedi } \\
\text { pauloensis }\end{array}$ & Miotoxina (BnSP-6) & 13,5 & Miotóxica & Rodrigues et al., 1998 \\
\hline $\begin{array}{l}\text { B. neuwiedi } \\
\text { pauloensis }\end{array}$ & Miotoxina (BnSP-7) & 13.727 & $\begin{array}{c}\text { Miotóxica, edematogênica, PLA2, } \\
\text { necrótica, } \\
\text { Inflamatória, antibacteriana, } \\
\text { bloqueadora neuromuscular, lítica de } \\
\text { membranas artificiais }\end{array}$ & $\begin{array}{l}\text { Rodrigues et al., 1998; } \\
\text { Soares et al., 2000; } \\
\text { Oliveira et al., } 2009\end{array}$ \\
\hline B. neuwiedi & $\begin{array}{l}\text { Proteína (bothrojaracin- } \\
\text { símile) }\end{array}$ & 27 & $\begin{array}{l}\text { Inibidora de trombina e indutora de } \\
\text { agregação plaquetária }\end{array}$ & Castro et al., 1999 \\
\hline B. neuwiedi & $\begin{array}{l}\text { Metalloprotease } \\
\text { (Neuwiedase) }\end{array}$ & 22 & $\begin{array}{c}\text { Fibrinogenolítica, miotóxica, } \\
\text { inflamatória, hemorrágica, } \\
\text { anti-Toxoplasma Gondii }\end{array}$ & $\begin{array}{l}\text { Rodrigues et al., 2000; } \\
\text { 2001; Bastos et al., } 2008\end{array}$ \\
\hline B. n. pauloensis & $\begin{array}{l}\text { BnpTX-I e } \\
\text { BnpTX-II }\end{array}$ & 14 & $\begin{array}{l}\text { Bactericida, neurotóxica, miotóxica, } \\
\text { edematogênica e citotóxica }\end{array}$ & Rodrigues et al., 2004 \\
\hline B. neuwiedi & PLA2 & $\sim 15$ & Bloqueador neuromuscular, PLA2 & Abreu et al., 2007 \\
\hline B. pauloensis & Fosfolipase (Bp-PLA2) & 15,8 & Edematoênica e miotóxica & Rodrigues et al., 2007 \\
\hline B. neuwiedi & Metalloprotease (BnP1) & 24 & $\begin{array}{c}\text { Miotóxica, hemorrágica, indutora de } \\
\text { apoptose, } \\
\text { fibrinogenolítica e fibrinolítica. }\end{array}$ & Baldo et al., 2008 \\
\hline B. pauloensis & PLA2 Lys49 (Bp-12) & 13.789 & Bloqueio neuromuscular & $\begin{array}{l}\text { Randazzo-Moura et al., } \\
2008\end{array}$ \\
\hline B. neuwiedi & $\begin{array}{l}\text { Peptídeos } \\
\text { recombinantes } \\
\text { (Neuwiedase) }\end{array}$ & $\mathrm{Nd}$ & Antigênica & Cardoso et al., 2009 \\
\hline B. pauloensis & $\begin{array}{l}\text { Enzima (Glicoproteína) } \\
\text { trombina-símile (BpSP- } \\
\text { I) }\end{array}$ & 34 & $\begin{array}{l}\text { Procoagulante e kallicreina-símile, } \\
\text { fibrinogenolítica, proteolítica }\end{array}$ & Costa et al., 2009 \\
\hline B. neuwiedi & $\begin{array}{l}\text { Metallopreteinase } \\
\text { (neuwiedase) }\end{array}$ & nd & Inflamatória & Lopes et al., 2009 \\
\hline B. pauloensis & LAAO (Bp-LAAO) & 65 & $\begin{array}{c}\text { Leishimanicida, antitumoral, } \\
\text { antibacteriana, indutora de agregação } \\
\text { plaquetária }\end{array}$ & Rodrigues et al., 2009 \\
\hline B. neuwiedi & Bn IV & 14 & Miotóxica & Delatorre et al., 2010 \\
\hline
\end{tabular}


Este estudo é justificado pela necessidade de se explorar o potencial biotecnológico dessas moléculas, contribuindo com a produção técnico-científica e, eventualmente, farmacêutica. Com o desenvolvimento do presente projeto, buscouse identificar e caracterizar a atividade citotóxica da peçonha bruta de Bothrops marmoratus, bem como da PLA2 isolada deste sobre células de adenocarcinoma cervical (HeLa) esperando aumentar o conhecimento sobre essa peçonha e fomentar a indústria farmacêutica com promissoras ferramentas farmacológicas.

\subsection{ESTUDOS JÁ REALIZADOS COM ESSA PEÇONHA}

A peçonha dessa serpente foi previamente estudada por nosso grupo (Macêdo 2011). Uma vez que o presente trabalho trata-se de uma continuação do que foi previamente realizado, consta a seguir um breve resumo dos resultados anteriormente obtidos.

No trabalho anterior descrevemos a purificação, identificação e caracterização bioquímica e biológica de diferentes proteínas com atividade antimicrobiana e antitumoral provenientes da peçonha de Bothrops marmoratus. A peçonha bruta foi fracionada com o emprego de cromatografia líquida de alta eficiência em coluna de fase reversa C18. Os ensaios para avaliação de atividade biológica foram realizados tanto com a peçonha bruta quanto com todas as frações cromatográficas obtidas, que somam 39 frações.

A atividade citotóxica provocada pelo tratamento com a peçonha bruta bem como com cada uma das frações foi avaliada pelo método do MTT. As alterações morfológicas causadas nas linhagens celulares HeLa (câncer cervical), B16F10 (câncer de pele) e NHI3T3 (fibroblastos normais) também foram avaliadas. Os ensaios para avaliação dos efeitos inibitórios sobre a proliferação de bactérias foram realizados com cinco linhagens de bactérias Gram-negativas, Escherichia coli (ATCC 25922), Pseudomonas aeruginosa (ATCC 27853), Enterobacter cloacae (ATCC 35030), Proteus mirabilis (ATCC 25933), Klesbsiella pneumoniae (ATCC 13884), além de quatro Gram-positivas, Staphylococcus aureus (ATCC 25923), Bacillus subtilis (ATCC 19659), Enterococcus faecalis (ATCC 29212) e Staphylococcus epidermidis (ATCC 12228). Além da ação das frações sobre células de mamíferos e bactérias, a atividade hemolítica sobre eritrócitos humanos (tipo $0, \mathrm{Rh}^{+}$) também foi testada. Os resultados mostram que diversas frações possuem atividade citotóxica de maneira 
dependente da linhagem celular testada, incluindo eritrócitos e bactérias apresentando diferentes valores de $\mathrm{IC}_{50}$ e MICs dependendo da amostra testada ou da linhagem celular utilizada.

Em seguida, a homogenenidade de cada fração e as massas moleculares dos seus componentes foram avaliadas por espectrometria de massas (MS) do tipo MALDI-TOF/TOF. Para análise por MS foram utilizadas três diferentes matrizes: ácido $\alpha$-ciano-4-hidroxicinâmico (HCCA) a $20 \mu \mathrm{g} / \mu \mathrm{L}$ em ACN 50\%, uma mistura de quantidades iguais de HCCA a $20 \mu \mathrm{g} / \mu \mathrm{L}$ (em ACN e ácido fórmico 5\% na proporção de 7:3) e de ácido dihidroxibenzóico (DHB) a $20 \mu \mathrm{g} / \mu \mathrm{L}$ (em ACN e TFA 0,1\% na proporção de 7:3) e a terceira matriz foi preparada com ácido sinapínico (SA) a 20 $\mu \mathrm{g} / \mu \mathrm{L}$ também em ACN 50\%.

Dentre as frações identificadas como bioativas, alguns parâmetros foram utilizados para selecionar as moléculas de interesse com as quais seriam realizadas as próximas etapas experimentais. São eles: a atividade sobre células tumorais, baixa atividade hemolítica, abundância de amostra. As frações que apresentavam todas essas características foram então recromatografadas e foram realizadas análises adicionais empregando-se espectrometria de massas.

Quatro frações foram selecionadas como sendo de interesse. A análise dessas frações por espectrometria de massas mostra que elas possuem similaridade com uma fosfolipase A2, uma lectina do tipo-C, uma serinoprotease e uma metaloprotease.

A fosfolipase A2 isolada foi chamada de BmPLA2 e apresentou resultados notadamente interessantes uma vez que apesar de não apresentar atividade fosfolipásica ou hemolítica, claramente reduziu a viabilidade das células testadas. Por essa razão, essa fosfolipase foi escolhida para o prosseguimento dos estudos. 
2. OBJETIVOS 


\section{OBJETIVOS}

\subsection{OBJETIVO GERAL}

Avaliar a atividade citotóxica da peçonha da serpente B. marmoratus e de uma fosfolipase A2 isolada, bem como a dinâmica do proteoma e da expressão gênica de células de câncer cervical (HeLa) em resposta ao tratamento com doses sub-letais da PLA2 isolada.

\subsection{OBJETIVOS ESPECÍFICOS}

- Avaliar os efeitos citotóxicos (fragmentação de DNA, integridade de membrana celular, mudanças no potencial de membrana mitocondrial) provocados pelo tratamento de células HeLa com a peçonha bruta de B. marmoratus;

- Determinar a melhor metodologia para purificação da PLA2.

- Avaliar a atividade citotóxica de uma PLA2 purificada no presente trabalho;

- Caracterizar a expressão gênica de células HeLa incubadas por diferentes tempos

- Caracterizar o proteoma de células de câncer cervical HeLa tratadas e não-tratadas com a PLA2 purificada no presente trabalho. 
3. MATERIAIS E MÉTODOS 


\section{MATERIAIS E MÉTODOS}

PRIMEIRA ETAPA: AVALIAÇÃO DA ATIVIDADE CITOTÓXICA DA PEÇONHA DE B. marmoratus

Os experimentos foram realizados de acordo com o desenho experimental descrito na figura 9.

\section{Desenho experimental}

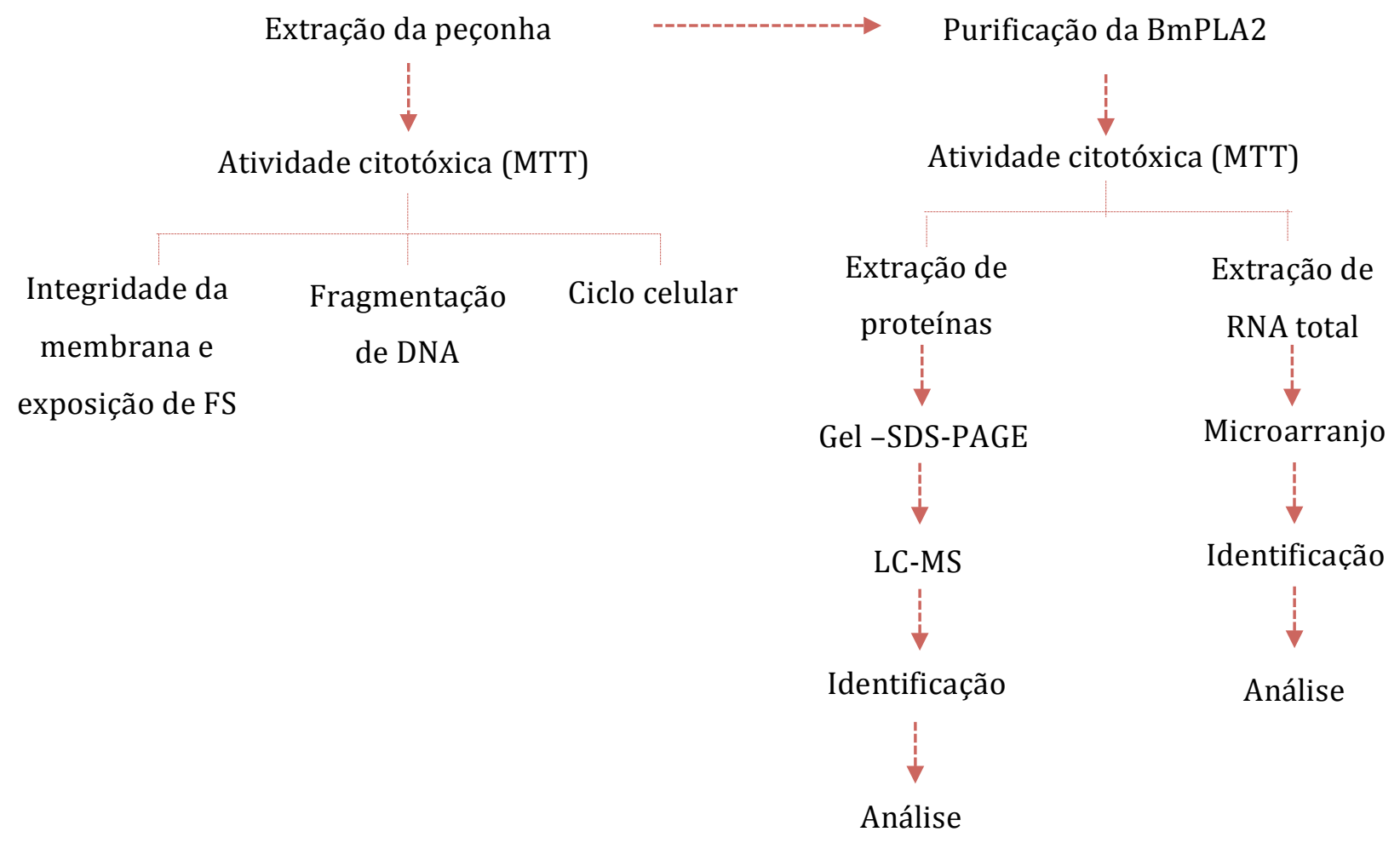

Figura 9| Fluoxograma do desenho experimental utilizado para desenvolvimento do presente trabalho.

\subsection{REAGENTES E PEÇONHA}

Todos os reagentes utilizados nas análises foram de grau analítico e obtidos de diferentes fornecedores comerciais. As soluções foram preparadas com água ultrapura Milli-Q® (Millipore Reagent Water System, USA). A peçonha foi obtida de serpentes classificadas morfologicamente como Bothrops marmoratus de acordo com Silva \& Rodrigues, 2008 e Carrasco et al., 2012. A peçonha foi obtida de espécimes mantidos em cativeiro no Núcleo Regional de Ofiologia de Goiânia 
(NUROG) da Pontifícia Universidade Católica de Goiás (PUC-GO). A extração da peçonha foi feita por meio de massagem manual das glândulas e reunida em microtubos para centrifugação. Após a coleta, o material obtido foi centrifugado a $12.000 \mathrm{rpm}$ por 15 minutos e apenas o sobrenadante foi coletado, imediatamente congelado em nitrogênio líquido e, em seguida, liofilizado. 0 material seco foi aliquotado e congelado a $-20^{\circ} \mathrm{C}$ até o momento do uso.

\subsection{MANUTENÇÃO DAS CÉLULAS}

As linhagens celulares tumorais HeLa (câncer do colo do útero humano, ATCC $^{\circledR}$ CCL- $^{\text {TM }}$ ), MCF7 (câncer de mama humano, ATCC ${ }^{\circledR}$ HTB-22 $^{\text {TM }}$ ), B16F10 (melanoma murino, ATCC ${ }^{\circledR}$ CRL-6475 ${ }^{\mathrm{TM}}$ ) e uma linhagem não tumoral, NIH/3T3 (fibroblasto murinho, ATCC ${ }^{\circledR}$ CRL-1658 ${ }^{\mathrm{TM}}$ ) foram obtidas do banco de células American Type Culture Collection (ATCC). Todos os procedimentos com células foram realizados no Laboratório de Nanobiotecnologia da Universidade de Brasília com materiais rigorosamente esterilizados em autoclave e posteriormente mantidos em câmara de fluxo laminar, cuja luz ultravioleta permaneceu ligada por 20 minutos antes do uso.

As linhagens mantidas em nitrogênio líquido foram descongeladas rapidamente a $37^{\circ} \mathrm{C}$ e as alíquotas foram lentamente adicionadas em tubos para centrífuga contendo $5 \mathrm{~mL}$ de meio de cultura DMEM (Dulbecco's Modified Eagle Medium) tamponado com bicarbonato de sódio, suplementado com 10\% de soro fetal bovino e 1\% de antibiótico (estreptomicina e penincilina). Os tubos foram então centrifugados a $1.000 \mathrm{rpm}$ por 3 minutos e o sobrenadante vertido sobre o descarte. As células sedimentadas no tubo foram ressuspendidas em $1 \mathrm{~mL}$ de meio DMEN completo e adicionadas a uma garrafa de cultura celular com área de cultivo de $25 \mathrm{~cm}^{2}$ contendo $5 \mathrm{~mL}$ de meio DMEN e foram incubadas em estufa a $37^{\circ} \mathrm{C}$ e $5 \%$ de $\mathrm{CO} 2$.

Após 24 horas do descongelamento, as células foram observadas em microscópio de luz invertida a fim de conferir sua aderência ao substrato além do perfil de crescimento celular, aspectos morfológicos e confirmada a ausência de contaminantes como bactérias ou fungos. As células foram mantidas nas garrafas até que atingissem o estágio de confluência, sendo que, a cada 48 horas, o meio de cultura era substituído e as células eram novamente observadas ao microscópio. 
Ao atingir o estágio de confluência, as células foram removidas do frasco de cultura com $3 \mathrm{~mL}$ de uma solução de tripsina-EDTA e centrifugadas a $1.000 \mathrm{rpm}$ por 3 minutos. 0 sobrenadante foi descartado e as células ressuspendidas em $1 \mathrm{~mL}$ de meio de cultura.

Para a determinação do número de células presentes nessa cultura, uma alíquota de $10 \mu \mathrm{L}$ da suspensão de células foi adicionada a $40 \mu \mathrm{L}$ de uma solução de azul de tripano (0,4\% p/v dissolvido em PBS) e uma alíquota de $10 \mu \mathrm{L}$ dessa mistura foi depositada em uma câmara de Neubauer, onde as células foram contadas em microscópio de luz. 0 número de células foi determinado multiplicando-se o número total de células contadas pelo fator de diluição das células com o azul de tripano (nesse caso, o fator foi 5), pela constante $10^{4}$ e, por fim, dividindo esse valor pelo número de quadrantes considerados na contagem (no caso, 4). A quantidade de células usadas no plaqueamento variou de acordo com o tipo de placa utilizada e será descrita nas próximas etapas.

\subsection{ANÁLISE DA VIABILIDADE CELULAR (MTT) E DETERMINAÇÃO DO IC 50}

Para o teste de viabilidade celular (MTT) foram utilizadas microplacas de 96 poços contendo $8 \times 10^{3}$ células por poço no caso das linhagens celulares HeLa, MCF7 e NIH/3T3 e 7 x $10^{3}$ células por poço no caso de B16F10. Após a adição das células, as placas permaneceram em estufa por 24 horas para que houvesse a completa adesão das células ao fundo da placa. Só então o meio de cultura de cada poço foi aspirado e substituído por $200 \mu \mathrm{L}$ de um novo meio contendo a peçonha bruta ou as frações isoladas e previamente esterilizadas por filtração com filtros Millex-GV 0,22 $\mu \mathrm{m}$ (Millipore ${ }^{\circledR}$ ).

As concentrações utilizadas para determinação do IC $_{50}$ consistiram em uma diluição seriada a partir de $500 \mu \mathrm{g} / \mathrm{mL}$ até $0,1 \mu \mathrm{g} / \mathrm{mL}$. Após a determinação do $\mathrm{IC}_{50}$ teórico (utilizando-se o software GraphPad Prism 5), uma confirmação experimental foi realizada utilizando a concentração teórica e mais 6 concentrações adjacentes, sendo 3 acima e 3 abaixo do ponto determinado como o $\mathrm{IC}_{50}$, de maneira a se obter uma curva experimental com mais pontos próximos ao valor do $\mathrm{IC}_{50}$.

A viabilidade celular foi avaliada pelo método de MTT estabelecido por Mosmann (1983). Trata-se de um método colorimétrico bastante utilizado em testes para identificação de novas moléculas anticâncer e para a determinação da faixa de concentração na qual tais toxinas apresentam atividade citotóxica. Em células 
metabolicamente viáveis, enzimas mitocondriais como a succinil-desidrogenase, reduzem o substrato MTT (3(4,5-dimetiltiazol-2-yl)-2,5-48 difeniltetrazólio bromido) formando o formazan, um produto de cor azulada que pode ser quantificado por espectrofotometria.

Após um período de incubação de 24 horas em estufa, o meio de cultura das placas foi removido e alíquotas de $150 \mu \mathrm{L}$ de solução de MTT (MTT 10\% em DMEM completo) foram adicionadas a cada poço. As células foram novamente incubadas por 3 horas na estufa. Em seguida, o MTT foi removido e 100 $\mu \mathrm{L}$ de DMSO adicionados a cada poço para lise celular, solubilização e posterior quantificação do formazan liberado pelas células viáveis. A quantificação foi realizada por meio de leitura da densidade óptica presente em cada poço com o emprego de uma leitora de microplacas (Multiskan ${ }^{\circledR}$, Thermo Scientific) no comprimento de onda de $595 \mathrm{~nm}$. 0 controle negativo foi obtido com o tratamento das células apenas com o meio de cultura e o controle positivo com peróxido de hidrogênio $\left(\mathrm{H}_{2} \mathrm{O}_{2}\right)$. Foi realizada a leitura de DMSO puro como branco.

A viabilidade celular foi determinada pela média da triplicata de cada concentração testada e os resultados foram analisados por ANOVA de duas vias seguido do pós-teste de Bonferroni. Foi considerado estatisticamente significativo $\mathrm{p}<0,05$. O IC 50 relativo, que é o ponto correspondente ao meio caminho entre os patamares superior e inferior da curva (e não ao valor que corresponde a $50 \%$ no eixo Y), e que representa a concentração em que a viabilidade celular foi reduzida em 50\% foi calculada utilizando-se o software GraphPad Prism 5.

\subsection{DETERMINAÇÃO DA INTEGRIDADE DE MEMBRANA CELULAR E APOPTOSE}

Alterações na membrana plasmática celular, especialmente a exposição de fosfatidilserina (PS), sinalizam aos fagócitos que as células estão entrando em apoptose. Para distinguir células apoptóticas (com exposição de PS e membrana plasmática intacta) daquelas não apoptóticas, mas com danos na membrana (por processo necrótico, por exemplo), iodeto de propídio (PI) é incluído na preparação e este só estará presente no interior celular, se houver algum dano de membrana (Martin et al. 1995).

0 ensaio foi realizado com $8 \times 10^{4}$ células (HeLa) e em placas de 12 poços e em triplicata. Após 24 horas de plaqueamento, as células foram tratadas com $1 \mathrm{~mL}$ da peçonha na concentração do $\mathrm{IC}_{50}$ encontrada no ensaio anterior $(5 \mu \mathrm{g} / \mathrm{mL})$. Após 
24 horas, o meio de cultura contendo a peçonha foi retirado e armazenado em tubos de microcentrífuga e foram adicionados $500 \mu \mathrm{L}$ de tripsina para recuperação das células. As placas foram então incubadas em estufa a $37^{\circ} \mathrm{C}$ por 3 minutos. Decorrido esse tempo, a tripsina foi diluída com a adição do respectivo meio de cultura que havia sido armazenado anteriormente. Em seguida, os tubos contendo as células foram centrifugados a $1.000 \mathrm{rpm}$ por 3 minutos e o sobrenadante foi descartado.

Após lavadas com PBS, as células foram ressuspendidas com $100 \mu \mathrm{l}$ do tampão de ligação (10 mM Hepes (pH 7.4)/ $140 \mathrm{mM} \mathrm{NaCl}$ 2,5 mM CaCl 2 ), $5 \mu \mathrm{L}$ de Anexina V FITC foi adicionada e, em seguida, $10 \mu \mathrm{L}$ de PI. As células em suspensão foram agitadas suavemente a temperatura ambiente e protegidas da luz. Após 15 minutos, uma alíquota de $400 \mu \mathrm{L}$ de tampão de ligação foi adicionada e as análises foram realizadas por citometria de fluxo, utilizando um FACSCalibur (Becton, Dickinson and Company, USA). Um total de 10.000 eventos foram coletados por amostra.

Neste experimento foram feitos controles negativo com células não tratadas; positivo para apoptose, sendo estas tratadas com $\mathrm{H}_{2} \mathrm{O}_{2} 150 \mu \mathrm{M}$ por $3 \mathrm{~h}$ e positivo para necrose, sendo aquecidas a $70^{\circ} \mathrm{C}$ por $20 \mathrm{~min}$.

\subsection{FRAGMENTAÇÃO DE DNA}

A fragmentação do DNA é uma característica muito marcante da morte por apoptose e possui um padrão característico, com fragmentos de DNA de tamanhos variáveis, mas sempre múltiplos de 180 a 200 pares de base (Saraste \& Pulkki 2000). A determinação da fragmentação de DNA foi realizada de acordo com protocolo descrito por Peres \& Curi (2005).

O ensaio foi realizado com $8 \times 10^{4}$ células (HeLa) e em placas de 12 poços e em triplicata. Após 24 horas de plaqueamento, as células foram tratadas com a peçonha na concentração equivalente a do IC $_{50}$ por 24 horas e as células foram recuperadas e lavadas como escrito anteriormente. Em seguida, as células foram ressuspendidas em $100 \mu \mathrm{L}$ de meio de cultura DMEN e incubadas em $200 \mu \mathrm{L}$ de tampão de lise $(0,1 \%$ de citrato de sódio, $0,1 \%$ Triton X-100 e $20 \mu \mathrm{g} / \mathrm{mL}$ de iodeto de propídio diluído em PBS, $\mathrm{pH}$ 7.4) por 30 minutos em temperatura ambiente. As amostras foram protegidas da luz durante o tempo de incubação.

Essa suspensão foi então avaliada em citômetro de fluxo no canal FL2-H (sensível a detecções na faixa de 560 e $580 \mathrm{~nm}$ ). Os dados obtidos foram analisados 
com o programa CellQuest 3.0.1 (Becton \& Dickinson, EUA). 0 cálculo da proporção de células em cada uma das fases do ciclo celular foi realizado considerando-se apenas as células com DNA não fragmentado. A significância das proporções das médias das triplicatas foi analisada por ANOVA de duas vias seguido do pós-teste de Bonferroni utilizando-se o software GraphPad Prism 5. Foi considerado estatisticamente significativo $\mathrm{p}<0,05$.

\subsection{DISTRIBUIÇÃO DE CÉLULAS NO CICLO CELULAR}

A identificação das fases do ciclo celular avalia se a peçonha bruta induz efeitos relacionados ao bloqueio da proliferação e do ciclo celular e fornece informações importantes, uma vez que a proliferação celular descontrolada é uma das principais características do câncer. Dessa forma, moléculas indutoras de efeitos citostáticos em células tumorais são promissoras para tratamentos terapêuticos dessa doença.

Esse teste foi realizado em triplicata e de acordo com protocolo descrito por Peres \& Curi (2005) e é realizado com a mesma amostra preparada no ensaio anterior (item 2.3.1). Todavia, o material foi agora avaliado em citômetro de fluxo no canal FL2-A (sensível a detecções na faixa de 560 e $580 \mathrm{~nm}$ ) para a identificação das fases do ciclo celular. Os dados obtidos foram analisados no programa CellQuest 3.0.1 (Becton \& Dickinson, EUA). A significância das proporções das médias das triplicatas foi analisada por teste de análise variância (ANOVA) de uma via seguida do teste de comparação múltipla de Bonferroni utilizando-se o software GraphPad Prism 5. Foi considerado estatisticamente significativo $\mathrm{p}<0,05$.

SEGUNDA ETAPA: PURIFICAÇÃO DA BmPLA2 E SUA AÇÃO EM CÉLULAS HELA

\subsection{PURIFICAÇÃO DA BmPLA2}

Diversas metodologias foram utilizadas a fim de se determinar as melhores condições para separação dos componentes da peçonha de B. marmoratus. Para definir a melhor metodologia, foram considerados parâmetros como eficiência da separação, resolução, manutenção da atividade biológica, tempo consumido para a 
adequada purificação da toxina de interesse e número de etapas exigido para atingir o grau de pureza desejado. Para isso, foram testadas uma coluna de troca iônica (Resource Q $1 \mathrm{~mL}$ ) em diferentes tampões (Tris-HCl 20 mM + NaCL 1 M/Tris-HCl 20 mM e NaCL 0,8 M/ $\mathrm{KH}_{2} \mathrm{PO}_{4} 20$ mM e KCL 0,4 M); uma coluna de exclusão molecular (Superdex 75 HR 10/30 GE ${ }^{\circledR}$ ) com diferentes tampões e valores de pH (Tris-HCl 20 $\mathrm{mM}$ pH 8,0/Tris-HCl $50 \mathrm{mM}$ pH 7,5/ $\mathrm{NH}_{4} \mathrm{HCO}_{2} 150 \mathrm{mM} \mathrm{pH} \mathrm{7,5),} \mathrm{seguidos} \mathrm{de}$ dessalinização com ultrafiltros Amicon de 0,5 mL para purificação e concentração de proteínas (Millipore ${ }^{\circledR}$ ) ou colunas HiTrap Desalting de $5 \mathrm{~mL}$ (GE Healthcare ${ }^{\circledR}$ ) e colunas de fase reversa $C_{18}$ ( Luna $5 \mu$ C18(2) 250 x 4.6 mm, Phenomenex ${ }^{\circledR}$ / Synergi $4 \mu$ Fusion RP 8250 x 4.6mm, Phenomenex ${ }^{\circledR} /$ Vydac 218TP54, 250 x 4,6 mm). 0 esquema abaixo (Figura 10) mostra todas os procedimentos testados.

O protocolo a seguir, descreve apenas o método que foi adotado na purificação da BmPLA2. A presente metodologia foi escolhida como método padrão por ter apresentado os melhores resultados, considerando-se os parâmetros previameante citados permitindo a sua purificação em uma única etapa cromtaográfica empregando-se coluna de fase reversa $\mathrm{C}_{18}$.

Alíquotas de 5,0 mg de peçonha bruta foram dissolvidas em $200 \mu \mathrm{L}$ de eluente A (TFA 0,1\% v/v em água Milli Q) e submetidas à centrifugação por $10 \mathrm{~min}$ a $10.000 \mathrm{rpm}$. 0 sobrenadante $(100 \mu \mathrm{L})$ foi aplicado em uma coluna de fase reversa $\mathrm{C}_{18}$, Vydac 218TP54, 250 x 4,6 mm, previamente equilibrada com o mesmo tampão, com fluxo de $1 \mathrm{~mL} / \mathrm{min}$. Para eluição das frações, empregou-se um gradiente linear de eluente B (TFA 0,1\% v/v em acetonitrila) e a detecção das frações foi realizada a 216 e $280 \mathrm{~nm}$ simultaneamente. As amostras foram coletadas manualmente em tubos de microcentrífuga, secos em Speed-Vac imediatamente após a coleta e mantidos congelados a $-20^{\circ} \mathrm{C}$ até o momento do uso. A dosagem de proteínas foi realizada utilizando o kit BCA (Thermo Scientific ${ }^{\mathrm{TM}}$ Pierce $^{\mathrm{TM}}$ Micro BCA $^{\mathrm{TM}}$ Protein Assay) com leitura a $562 \mathrm{~nm}$. 


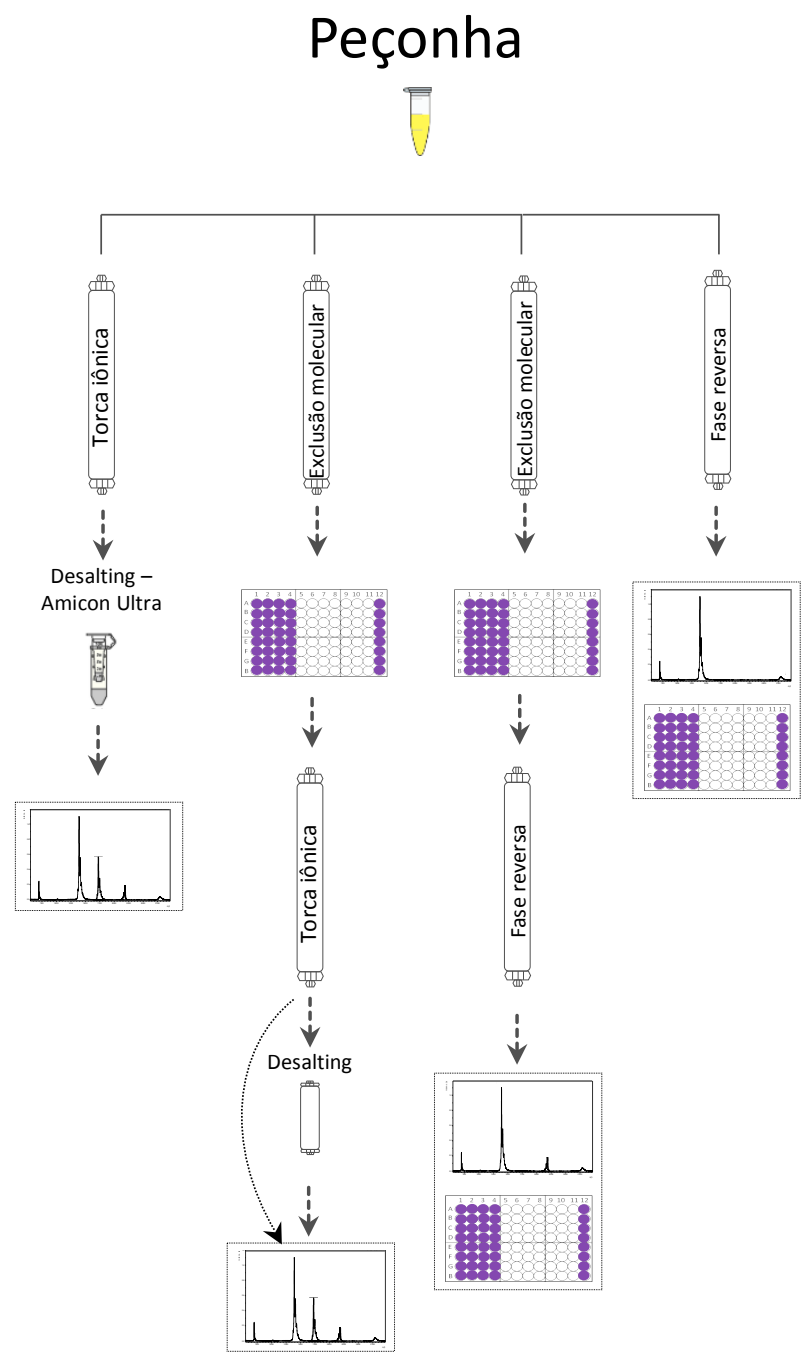

Figura 10| Ilustração esquemática de todas as etapas testadas inicialmente na purificação da fosfolipase A2 de Bothrops marmoratus. As colunas de exclusão molecular e troca iônica foram testadas com diferentes tampões e metodologias. A avaliação da atividade citotóxica das frações cromatográficas foi realizada empregando-se MTT (simbolizada na ilustração pelo desenho da placa de 96 poços na cor lilás) e a homogeneidade das frações de interesse foi avaliada por espectrometria de massas do tipo MALDI (simbolizado no esquema pelo espectro de massas).

\subsection{ANÁLISES POR ESPECTROMETRIA DE MASSAS (MALDI)}

As massas moleculares experimentais das frações obtidas foram determinadas em espectrômetro de massas do tipo MALDI-TOF/TOF Autoflex II (Bruker Daltonics, Bremen, Germany). Cada fração foi dissolvida em $200 \mu \mathrm{L}$ de TFA $0,1 \%(\mathrm{v} / \mathrm{v})$ e $1 \mu \mathrm{L}$ da fração foi aplicado sobre os poços de uma placa de aço inoxidável específica para análise por MALDI. Logo em seguida, o mesmo volume de 
matriz foi adicionado à amostra e essa mistura foi homogeneizada aspirando-se o líquido presente no poço com a própria micropipeta. Foram utilizados 2 tipos de matriz para análise da composição peptídica/protéica de cada fração. A primeira foi preparada com ácido $\alpha$-ciano-4-hidroxicinâmico (HCCA) a $20 \mu \mathrm{g} / \mu \mathrm{L}$ em acetonitrila $30 \%(\mathrm{v} / \mathrm{v}) / \mathrm{TFA} 0.1 \%(\mathrm{v} / \mathrm{v})$. A faixa de $\mathrm{m} / \mathrm{z}$ empregada nessas análises foi de 500 a 5.000 Da. Para calibração do equipamento foi utilizado $1 \mu \mathrm{L}$ da solução Peptide Mix (Brucker Daltonics) com o mesmo volume de matriz e as amostras foram analisadas em modo refletor-positivo. A segunda matriz empregada foi ácido sinapínico (SA) $20 \mu \mathrm{g} / \mathrm{mL}$ em acetonitrila 50\% (v/v) e foi utilizada detecção entre 4.000 e $100.000 \mathrm{Da}$. As amostras diluídas em SA foram analisadas em modo linear-positivo e o equipamento foi previamente calibrado com uma solução Protein Mix (Brucker Daltonics), preparada da mesma forma que a solução de peptídeos.

\subsection{ANÁLISE PROTEÔMICA}

\subsubsection{Tratamento e extração de proteínas}

Para análise proteômica $0,6 \times 10^{6}$ células HeLa foram cultivadas em frascos de cultura de $25 \mathrm{~cm}^{2}$ e, após 24 horas, tratadas com a BmPLA2 na concentração equivalente ao seu IC $_{50}$ por mais 24 horas nas mesmas condições descritas previamente. Para a lise celular e extração de proteínas, inicialmente lavou-se cuidadosamente as garrafas com PBS gelado por 2 vezes. Em seguida, $1 \mathrm{~mL}$ de tampão de extração de proteínas - RIPA (Sigma Aldrich®), contendo inibidor de proteases Pefabloc SC $₫$ PLUS (Roche $囚$ ) foi adicionado e as placas foram mantidas em gelo durante 5 minutos, com ocasionais homogeneizações sendo realizadas durante esse período. As células residuais ainda aderidas aos frascos foram completamente removidas utilizando um raspador descartável.

Para clarificação, a solução contendo as amostras em tampão RIPA foram centrifugadas a 20.000 g por $30 \mathrm{~min}$ a $4^{\circ} \mathrm{C}$. 0 sobrenadante foi misturado a uma solução clorofórmio/methanol (2:1) na proporção de 5:1 de amostra. Em seguida, essa mistura foi agitada e novamente centrifugada a $20.000 \mathrm{~g}$ por $30 \mathrm{~min}$ a $4^{\circ} \mathrm{C}$. A camada de proteínas extraída foi removida, lavada com metanol gelado e, após centrifugação, o precipitado foi solubilizado em tampão de amostra para eletroforese (Bio-RAD) contendo $5 \%(\mathrm{v} / \mathrm{v})$ de 2-mercaptoetanol, fervido a $95^{\circ} \mathrm{C}$ 
durante 10 min e sonicado. A dosagem de proteínas foi realizada utilizando o kit BCA (Thermo Scientific ${ }^{\mathrm{TM}}$ Pierce $^{\mathrm{TM}}$ Micro BCA ${ }^{\mathrm{TM}}$ Protein Assay) com leitura a $562 \mathrm{~nm}$.

\subsubsection{Eletroforese em gel de poliacrilamida (SDS-PAGE)}

As amostras solubilizadas foram submetidas à eletroforese em gel SDS-PAGE sob condições desnaturantes. Vinte microgramas de amostra ressuspendida em tampão Laemmli foram aplicados a um gel pré-moldado Any- $\mathrm{kD}^{\mathrm{TM}}$ Criterion $^{\mathrm{TM}} \mathrm{TGX}^{\mathrm{TM}}$ (Bio-Rad). A corrida foi realizada por 45 minutos a $200 \mathrm{~V}$ e, em seguida, o gel foi corado com Coomassie Brilliant Blue 0,1\% (m/v)/metanol 40\% (v/v)/ácido acético $10 \%(\mathrm{v} / \mathrm{v})$ por 1,5 hora e finalmente descorado com metanol (v/v)/ácido acético $10 \%(\mathrm{v} / \mathrm{v})$ e mantido em ácido acético $5 \%(\mathrm{v} / \mathrm{v})$. Cada linha do gel foi cortada em dez fatias aproximadamente equivalentes e descoradas por 3 horas. As proteínas foram reduzidas com DTT $10 \mathrm{mM}$ e alquiladas com iodoacetamida $50 \mathrm{mM}$ à temperatura ambiente e digeridas com uma solução de tripsina modificada (20 ng/ $\mu \mathrm{L}$ ) (Promega) em bicarbonato de amônio $50 \mathrm{mM}$ por 30 minutos no gelo. 0 excesso de tripsina foi removido e a digestão prosseguiu por mais $18 \mathrm{~h}$ a $37^{\circ} \mathrm{C}$. Os peptídeos trípticos foram extraídos do gel com $30 \mu \mathrm{L}$ de uma solução contendo acetonitrila $50 \%(\mathrm{v} / \mathrm{v}) /$ ácido fórmico $5 \%(\mathrm{v} / \mathrm{v})$ por duas vezes. Os peptídeos extraídos foram concentrados até um volume de $15 \mu \mathrm{L}$ para posterior análise por LC-MS/MS.

\subsubsection{LC-MS/MS}

Os experimentos de LC-MS/MS foram realizados utilizando-se um espectrômetro de massa Orbitrap Velos ETD (Thermo Scientific ${ }^{\mathrm{TM}}$ ). Colunas analíticas foram fabricadas empacotando-se $0,5 \mathrm{~cm}$ de esferas irregulares $\mathrm{C}_{18}$ (YMC Gel ODS-A, $12 \mathrm{~nm}, \mathrm{I}-10-25 \mathrm{um}$ ) seguido por 7,5 cm de material $\mathrm{C}_{18}$ Jupiter $10 \mu \mathrm{m}$ (Phenomenex, Torrance, CA) em uma coluna com dimensões 360 x $75 \mu \mathrm{m}$ (Polymicro Technologies, Phoenix, AZ). Alíquotas contendo as amostras foram inseridas diretamente nas colunas $(7 \mu \mathrm{L})$ e os peptídeos foram eluídos com um fluxo de $0,5 \mu \mathrm{L} / \mathrm{min}$, com gradiente de 2-90\% de acetonitlila/0.1 M ácido acético por 1 hora.

0 instrumento foi programado para adquirir um ciclo completo $(\mathrm{m} / \mathrm{z} 300$ 1600) com resolução de 60.000 seguido por etapa de MS/MS (por dissociação induzida por colisão - CID) dos vinte íons mais abundantes. Uma lista de exclusão dinâmica com 400 massas moleculares foi ativada por 60 segundos para permitir 
uma melhor faixa dinâmica e prevenir análises repetidas do mesmo íon. A voltagem do eletrospray foi programada para $2,4 \mathrm{kV}$ e a temperatura do capilar $265^{\circ} \mathrm{C}$.

A lista de íons foi obtida usando o algoritmo Sequest do pacote Proteome Discoverer 1.4.1 contra o banco de dados Uniprot de julho de 2014. Os espectros gerados foram pesquisados usando carbamidometilação das cisteínas como uma modificação fixa e oxidação da metionina como uma modificação variável, além de 10 ppm de tolerância no íon parental e 1 Da de tolerância para fragmentos. Todas as ocorrências foram necessariamente trípticas. Os resultados foram exportados para o software Scaffold (versão 4.3.2, Proteome Software Inc, Portland, OR). O software Scaffold foi usado para validar as identificações de proteínas e peptídeos e para visualizar os dados.

As identificações de proteínas foram filtradas usando valores de corte Xcorr dependentes do estado de carga $(+1>1.8,+2>2,2,+3>2.5$ and $+4>3.5)$. No Scaffold, essas identificações são apresentadas como uma probabilidade indicando uma faixa entre 80 a 94\% e acima de 95\% de confiança. A quantificação relativa de proteínas foi obtida plotando-se todas as proteínas contidas nas 10 fatias de uma amostra específica em um único arquivo e, em seguida, calculando-se o valor quantitativo, que é um valor normalizado da quantidade de espectros (http://www.proteomesoftware.com/).

\subsection{EXPRESSÃO GÊNICA}

A análise transcriptômica e identificação de genes diferencialmente expressos em células tratadas ou não com a BmPLA2 na concentração equivalente ao IC $_{50}$ com diferentes tempos de incubação foi realizada usando-se a técnica de microarranjo. Células HeLa $\left(0,6 \times 10^{6}\right)$ foram cultivadas em frascos de cultura de 25 $\mathrm{cm}^{2}$ e, após 24 horas o meio foi substituído por um novo meio contando a BmPLA2 na concentração equivalente ao $\mathrm{IC}_{50}$ e permaneceu por diferentes tempos $(2 \mathrm{~h}, 12 \mathrm{~h}$ e 24h).

Os procedimentos de isolamento de RNA total, síntese de cDNA, marcação de cRNA, hibridização do microarranjo e aquisição das imagens foram realizados de acordo com instruções do fabricante (Affymetrix, Inc). As amostras de cRNA obtidas foram fragmentadas e os fragmentos de 30-200 nucleotídeos hibridizados por uma noite em lâminas de microarranjo Affymetrix GeneChip® Human Gene 2.0 ST. Esses chips contêm sondas de oligonucleotídeos para uma cobertura de 40.716 transcritos 
identificados pelo RefSeq, sendo 30.654 codificantes, 5,638 não codificantes, além de lincRNAs e algumas notações provisórias (considerando-se o banco de dados RefSeq de fevereiro de 2012). Os experimentos foram realizados no Centro de Pesquisa Biomolecular (Biomolecular Research Facility - DNA Sciences) da Faculdade de Medicina da Universidade da Virginía, USA.

Após a obtenção dos resultados, o software dChip (Schadt et al., 2001) foi utilizado para interpretação dos dados gerados. A análise comparativa das amostras foi realizada baseada na alteração da expressão gênica (fold change). Mudanças maiores que 1,5 ou menores que 0,5 foram consideradas significativas.

\subsection{ANÁLISES COMPUTACIONAIS}

O banco de dados para anotação, visualização e descoberta integradas (DAVID Bioinformatics Resources 6.7, NIAID/NIH) (Huang et al., 2009) foi utilizado com o propósito de extrair sistematicamente o significado biológico das listas de proteínas e genes obtidos por proteômica e expressão gênica. Os termos do Gene Ontology (GO), bem como as vias biológicas alteradas e grupos funcionais de genes e proteínas foram obtidos por meio desta ferramenta. 
4. RESULTADOS 


\section{RESULTADOS}

PRIMEIRA ETAPA: AVALIAÇÃO DA ATIVIDADE CITOTÓXICA DA PEÇONHA DE B. marmoratus

\subsection{EFEITO CITOTÓXICO DA PEÇONHA BRUTA}

\subsubsection{Análise da viabilidade celular (MTT) e determinação do IC $_{50}$}

Os resultados da análise da viabilidade celular após o tratamento com BmPLA2 indicam que a peçonha bruta, na maior concentração utilizada, reduziu a viabilidade de células HeLa para 5,88\% de células B16F10 para 2,5\% e de fibroblastos NIH/3T3 para 11,8\% . Tal efeito é diminuído à medida em que a concentração da peçonha é reduzida (Figura 11).

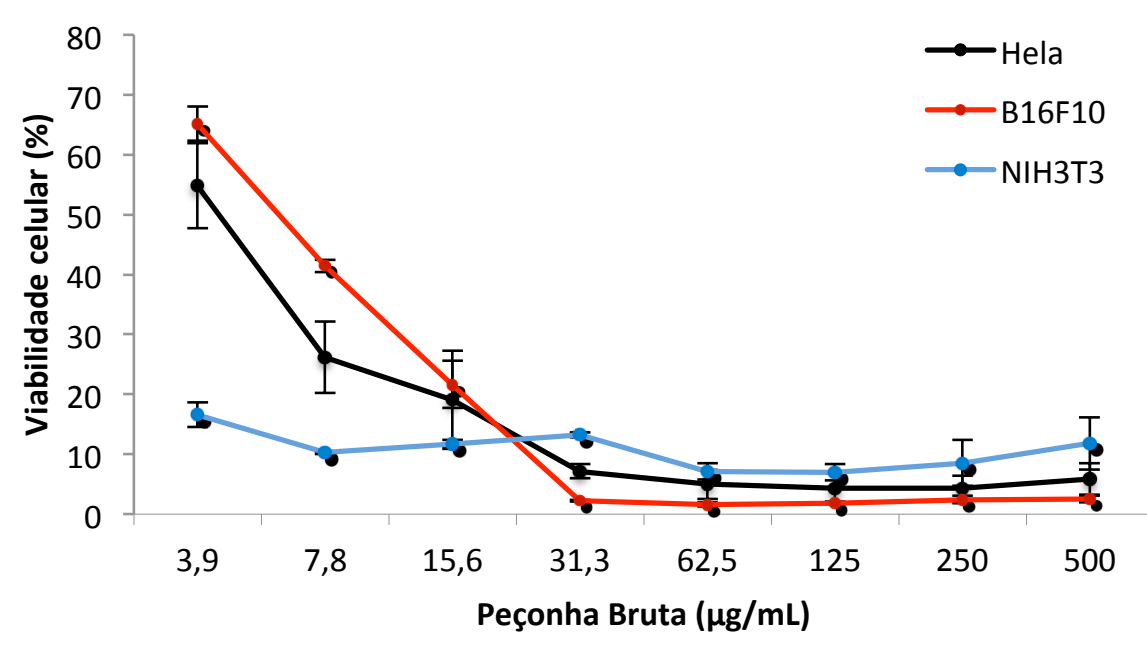

Figura 11| Redução da viabilidade celular causada pela peçonha bruta de $B$. marmoratus após $\mathbf{2 4 h}$ de incubação. 0 ensaio foi realizado com células HeLa (câncer do colo do útero humano), B16F10 (melanoma murino) e NIH-3T3 (fibroblasto murino), de acordo com o método do MTT. Os resultados estão apresentados como a média dos valores obtidos em triplicata.

A análise estatística foi realizada por ANOVA de duas vias seguida do teste de comparação múltipla de Bonferroni e os resultados demonstram que, em algumas concentrações testadas, a ação da peçonha sobre as linhagens celulares testadas foi expressivamente diferente. Quando comparamos as linhagens tumorais com a linhagem normal, na maior concentração utilizada de $500 \mu \mathrm{g} / \mathrm{mL}$, é possível notar 
que a peçonha tem um efeito maior sobre células tumorais do que sobre a linhagem normal, sendo que essa diferença foi significativa apenas em melanoma. Todavia, nas concentrações entre 3,9 e 15,6 $\mu \mathrm{g} / \mathrm{mL}$, a linhagem normal foi mais suscetível à toxina do que as linhagens tumorais (Figura 11). O $\mathrm{IC}_{50}$ encontrado foi de $5 \mu \mathrm{g} / \mathrm{mL}$ para HeLa, 2,5 $\mu \mathrm{g} / \mathrm{mL}$ para B16F10 e 2,2 $\mu \mathrm{g} / \mathrm{mL}$ para NIH/3T3.

\subsubsection{Determinação da integridade de membrana celular e apoptose - AnexinaV FITC/PI}

A determinação da apoptose e necrose por meio da avaliação da integridade da membrana plasmática e externalização de fosfatidilserina foram avaliadas em células HeLa por citometria de fluxo. Os resultados mostram um aumento relevante da proporção de células entrando em apoptose, além de uma discreta alteração na proporção de células com marcação para apoptose e necrose quando comparamos o grupo tratado com a peçonha de B. marmoratus e o grupo controle. A figura 12 mostra que a porcentagem de células entrando em apoptose no grupo controle é de $1,9 \%$, enquanto no grupo tratado esse valor sobe para $71,7 \%$, sendo estatisticamente significativo. A porcentagem de células que apresentam apenas dano de membrana permanece irrelevante após o tratamento, porém, o número de células com marcação duplamente positiva, ou seja, com dano de membrana e marcação para fosfatidilserina sofre uma alteração discreta, de 0,6\% no grupo controle para 2,5\% nas células tratadas.

\subsubsection{Fragmentação de DNA}

A análise por citometria de fluxo para determinação da fragmentação de DNA mostrou que a porcentagem média de DNA fragmentado aumentou aproximadamente 4,5 vezes nas células tratadas em relação ao controle $(18,3 \%$ versus $4,1 \%$ ). De acordo com o teste estatístico empregado (teste t) esse aumento foi significativo $(t=13,02, d f=6, p<0,001)$ (Figura 13). 


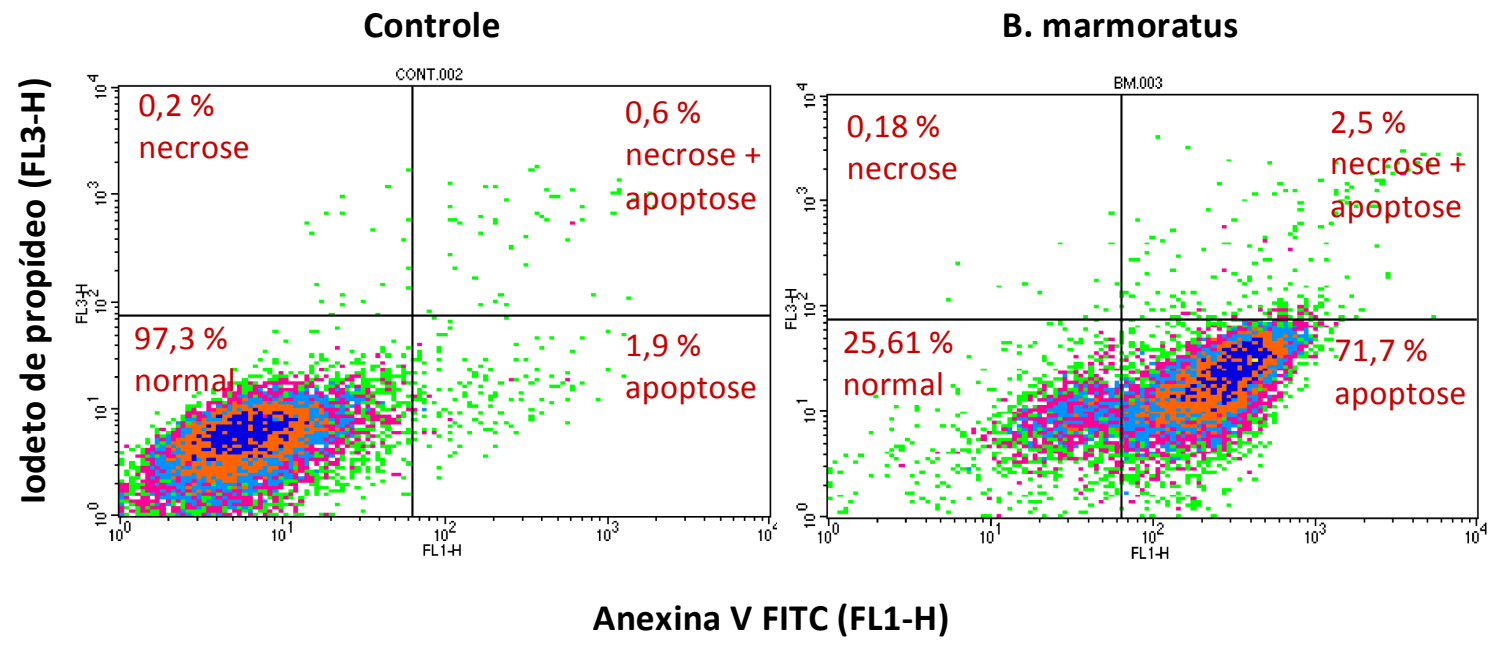

Figura 12| Quantificação da apoptose e necrose em células HeLa por citometria de fluxo utilizando Anexina V-FITC e PI. As céllas foram incubadas com ou sem $5 \mu \mathrm{g} / \mathrm{mL}$ da peçonha de B. marmoratus por $24 \mathrm{~h}$.

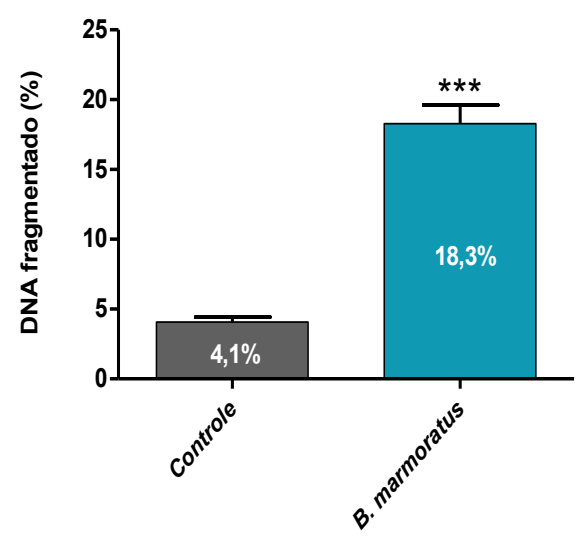

Figura 13| Porcentagem de DNA fragmentado após o tratamento com $5 \mu \mathrm{g} / \mathrm{mL}$ da peçonha de B. marmoratus por $\mathbf{2 4 h}$. 0 ensaio foi realizado com células HeLa e com o uso de iodeto de propídeo. Resultado apresentado como a média \pm desvio padrão. A análise estatística foi feita pelo teste t. ${ }^{* * *}: \mathrm{p}<0.001$.

\subsubsection{Distribuição de células no ciclo celular}

A análise do ciclo celular demonstrou que parte das células não está passando da Fase S para a fase G2, o que é evidenciado pelo aumento de células na fase S (11,6\% versus 13,5\%). A análise estatística por ANOVA seguida do teste de 
comparação múltipla de Bonferroni indicou que esse aumento é estatisticamente significativo $(\mathrm{F}=12930 \mathrm{P}=0,0001)$ (Figura 14).

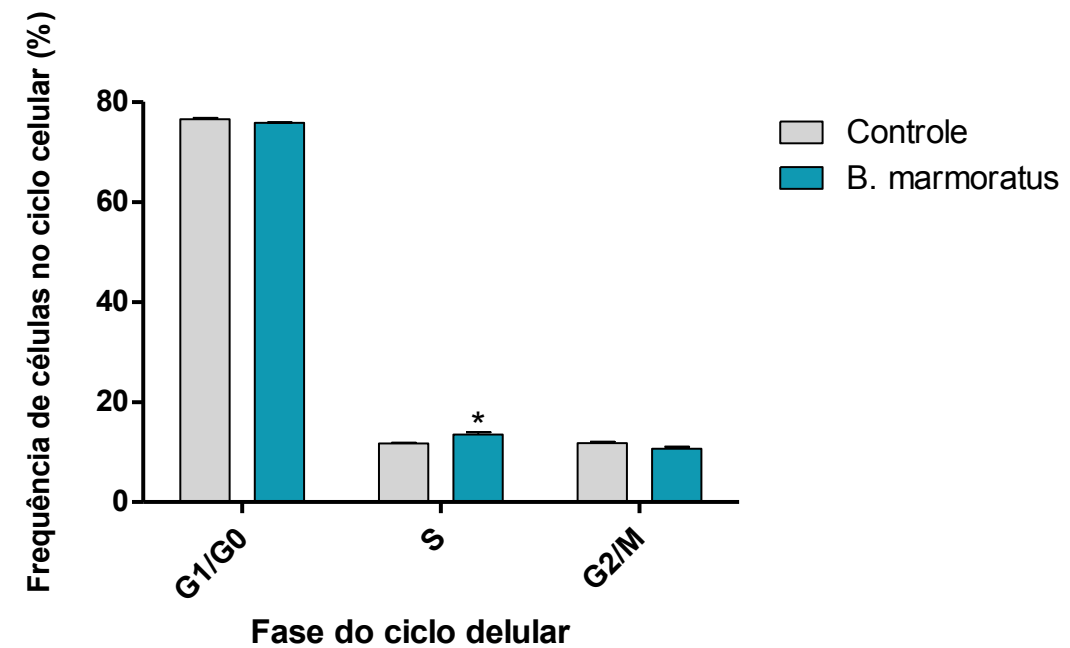

Figura 14| Proporção de células nas diferentes fases do ciclo celular tratadas ou não com com $5 \mu \mathrm{g} / \mathrm{mL}$ da peçonha de B. marmoratus por 24 horas. 0 ensaio foi realizado com células HeLa e a proporção de células foi determinada com o uso de iodeto de propídeo. Os resultados estão apresentados como a média \pm desvio padrão. A análise estatística foi feita por ANOVA, seguido pelo teste de comparação múltipla de Bonferroni. *: p<0,05.

SEGUNDA ETAPA: PURIFICAÇÃO DA BmPLA2 E SUA AÇ̃̃O EM CÉLULAS HELA

\subsection{PURIFICAÇÃO DA BMPLA2 E DETERMINAÇÃO DO SEU GRAU DE HOMOGENEIDADE}

Como citado na seção Materiais e Métodos, diversas metodologias foram utilizadas a fim de se determinar as melhores condições para separação dos componentes da peçonha de B. marmoratus. As técnicas cromatográficas empregadas envolveram troca iônica, exclusão molecular e fase reversa.

O uso de cromatografia por troca iônica permite que famílias de moléculas (ácidas, básicas e neutras) sejam separadas com base na sua carga. Esta é uma técnica cromatográfica bastante utilizada para purificação de proteínas, todavia possui baixa resolução quando empregada para separação de misturas proteicas muito complexas como os venenos e peçonhas animais, exigindo frequentemente diversos passos de purificação. $\mathrm{O}$ fracionamento da peçonha em coluna Resource $\mathrm{Q}$ 
(GE Healthcare ${ }^{\circledR}$ ) apresentou um perfil com três grupos ou famílias de moléculas (Figura 15) e devido ao baixo poder de resolução mesmo quando testado com tampões e pHs diferentes, foi descartado como metodologia para a separação da PLA2.

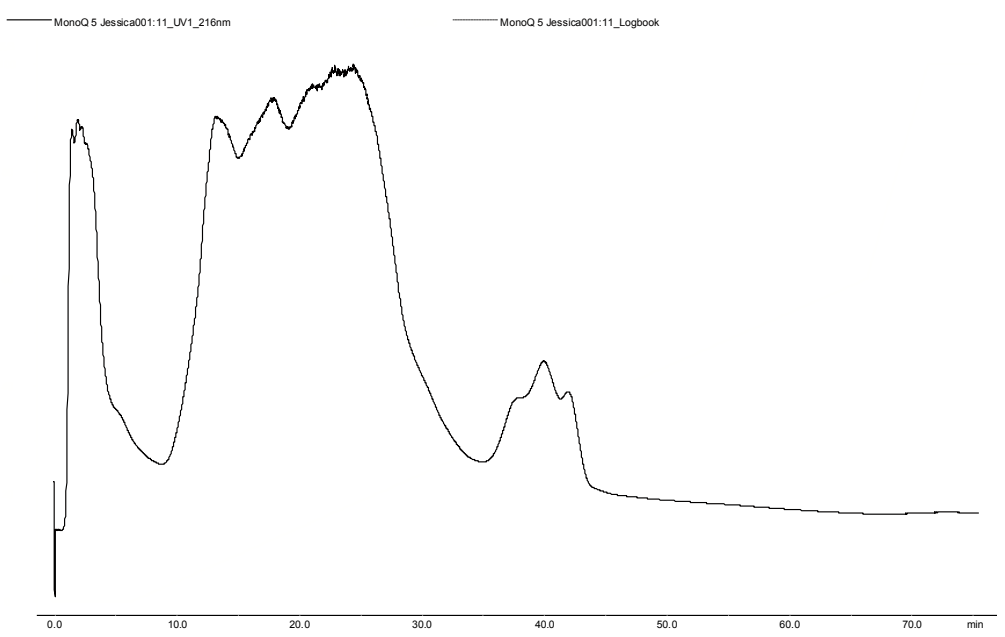

Figura 15| Perfil cromatográfico da peçonha bruta de B. marmoratus em coluna de Troca iônica. Cromatografia por troca iônica/Solvente A: Tris-HCl 20mM pH 8,0/Solvente B: $\mathrm{NaCl} 1 \mathrm{M} \mathrm{pH} 8,0 /$ Fluxo: $0.5 \mathrm{~mL} / \mathrm{min}$

Também foi realizada uma análise de massa das frações obtidas por troca iônica utilizando a matriz ácido sinapínico, contudo os resultados evidenciaram a presença de muitos componentes por fração (dados não mostrados), o que prova a baixa eficiência dessa coluna para esse tipo de amostra.

Outra coluna utilizada no isolamento da PLA2 da peçonha de B. marmoratus foi a de exclusão molecular Superdex G75. Como é possível observar na figura 16, o uso desta técnica permitiu a eluição de 11 frações, as quais foram testadas quanto à atividade citotóxica contra as linhagens celulares tumorais de colo uterino HeLa e glândula mamária MCF7, antes da próxima etapa cromatográfica composta por uma coluna $\mathrm{C}_{18}$ (fase reversa). Foi possível observar que a presença do tampão Tris-HCL, na concentração utilizada para a separação cromatográfica, que foi de 0,05 M, após ser seco em Speed-Vac, não tem efeito citotóxico sobre essas células, o que permite sua utilização para realizar os ensaios com MTT sem dessalinização prévia. Apesar dessa metodologia ter apresentado sucesso quanto ao isolamento da PLA2 e manutenção da atividade biológica, o tempo consumido para preparação das cromatografias foi considerado insatisfatório. Além disso, outra grande 
desvantagem é em relação à reprodutibilidade da primeira etapa, que foi considerada baixa.

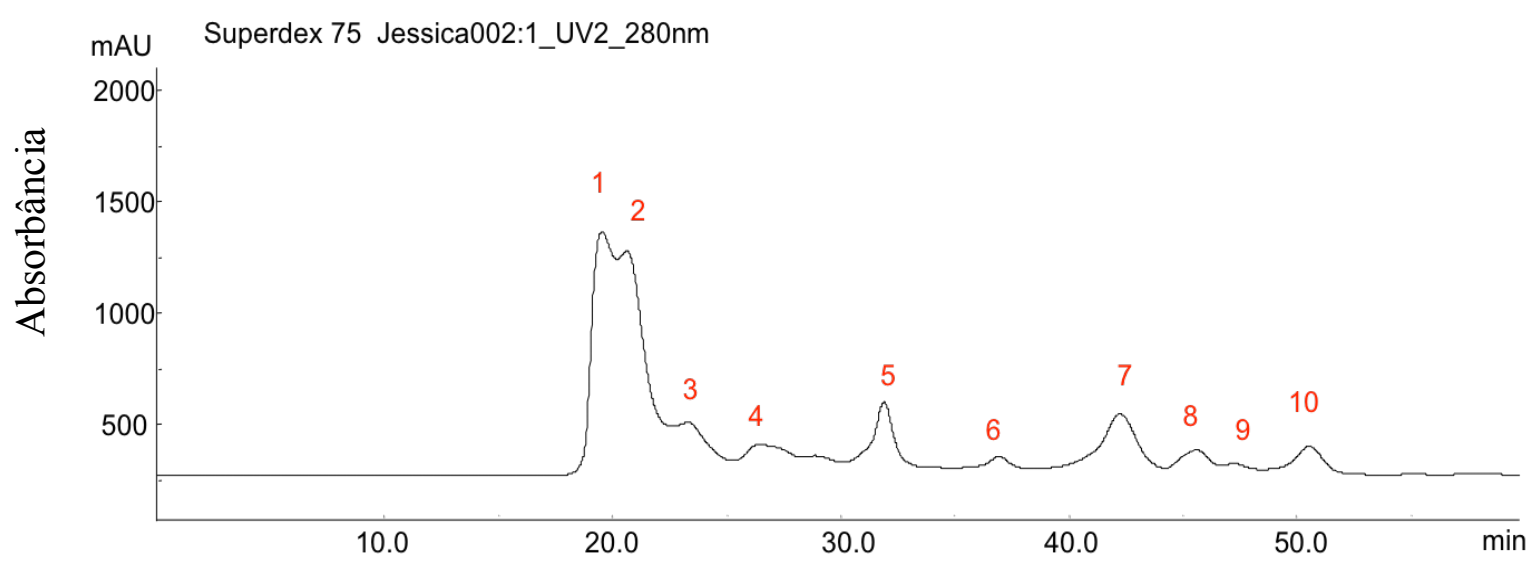

Tempo de retenção (min.)

Figura 16| Perfil cromatográfico da peçonha bruta de B. marmoratus em coluna de exclusão molecular. $O$ fracionamento obtido empregando-se coluna de exclusão molecular Superdex 75 HR 10/30 (GE Healthcare). A eluição foi realizada em modo isocrático com um fluxo de $0,8 \mathrm{~mL} / \mathrm{min}$ de tampão Tris-HCl $0,05 \mathrm{M} \mathrm{pH} \mathrm{7,5} \mathrm{e} \mathrm{detecção} \mathrm{a} 216 \mathrm{~nm}$. Os números destacados em vermelho correspondem aos números usados para nomear as recromatografias na etapa subsequente.

Antes de seguir para a etapa de recromatografias, as frações obtidas por exclusão molecular foram testadas quanto a atividade citotóxica contra as linhagens celulares tumorais de colo uterino HeLa e glândula mamária MCF7. O resultado mostra que a atividade é mantida após essa separação cromatográfica e encontra-se principalmente nas frações 1 e 2 (Figura 17). Também é possível observar que a presença do tampão Tris-HCL, na concentração utilizada para a separação cromatográfica, que é de 0,05 M, após ser seco em Speed-Vac, não tem efeito citotóxico sobre essas células, o que permite sua utilização para realizar ensaio de MTT sem dessalinização prévia. 


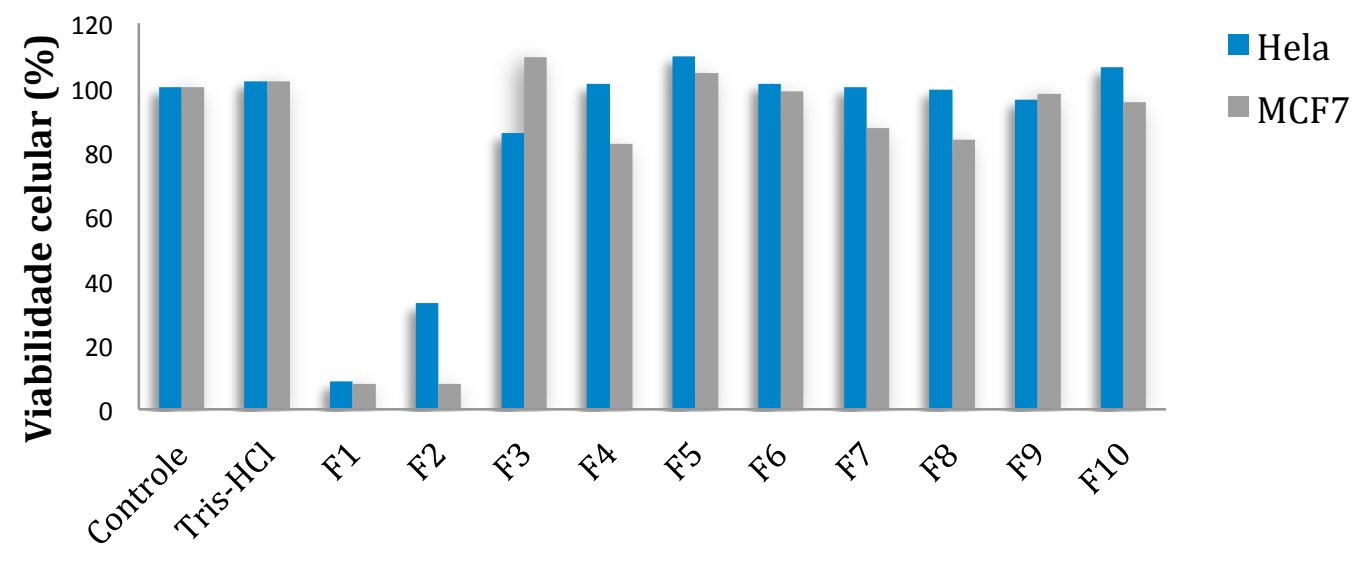

Frações

Figura 17| Viabilidade celular (\%) das células tumorais HeLa e MCF7 após incubação por $24 \mathrm{~h}$ com as frações cromatográficas da peçonha de $B$. marmoratus obtidas por cromatografia de exclusão molecular.

Ensaios preliminares desenvolvidos previamente (Macêdo 2011) demonstraram que essa PLA2 perde sua atividade quando submetida a mais de uma etapa cromatográfica em fase reversa. Dessa maneira, sua obtenção em apenas uma etapa cromatográfica, tornou-se de extrema prioridade. A cromatografia realizada em coluna de fase reversa $\mathrm{C}_{18}$ resultou na eluição de cerca de 50 frações (Figura 18A) e os perfis cromatográficos apresentaram-se reprodutíveis. A fração de interesse, chamada BmPLA2, foi coletada com o tempo de retenção de 35,54 minutos e eluição em aproximadamente $35 \%$ do solvente B. A análise do grau de homogeneidade dessa fração e das massas moleculares dos componentes aí presentes foi realizada por eletroforese desnaturante (SDS-PAGE) e por espectrometria de massas do tipo MALDI-TOF. Tais análises demonstraram a eficiência do método cromatográfico empregado e a massa molecular da BmPLA2 determinada por espectrometria de massas foi igual a 13.728,66 $[\mathrm{M}+\mathrm{H}]^{+}($Figura 18-B e C). 


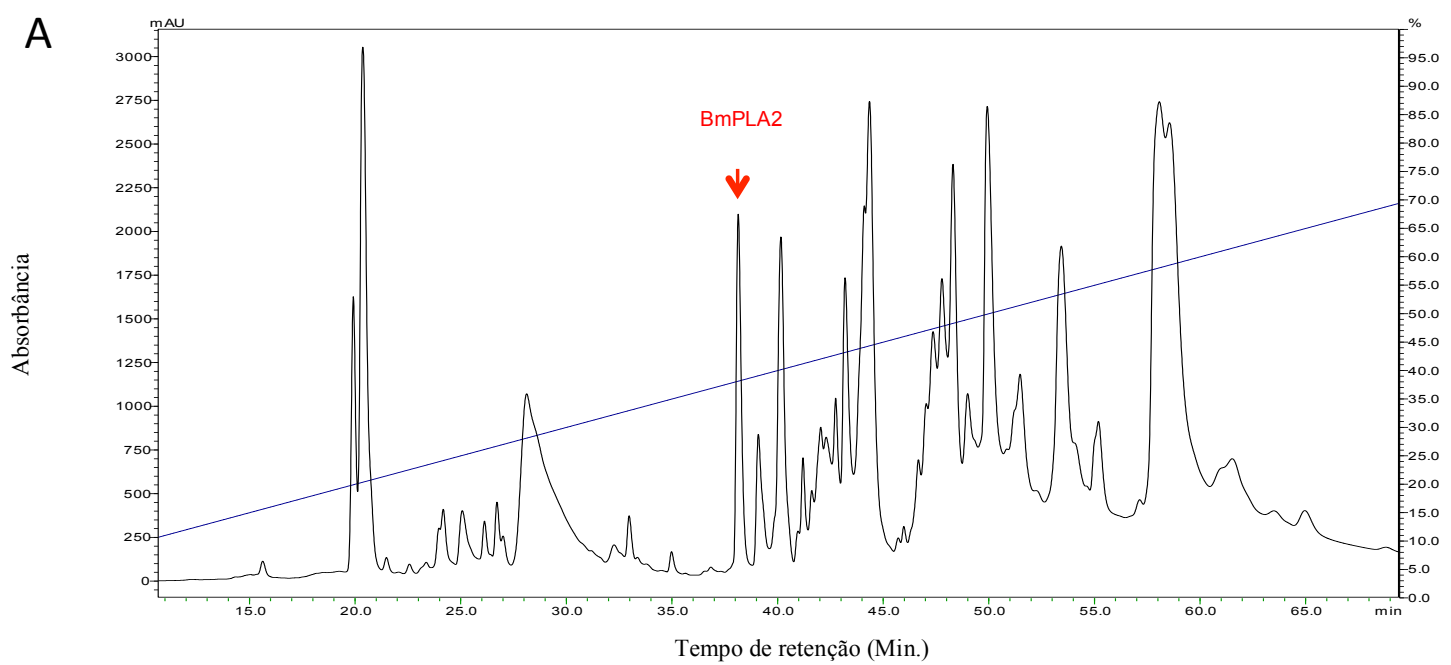

B

C
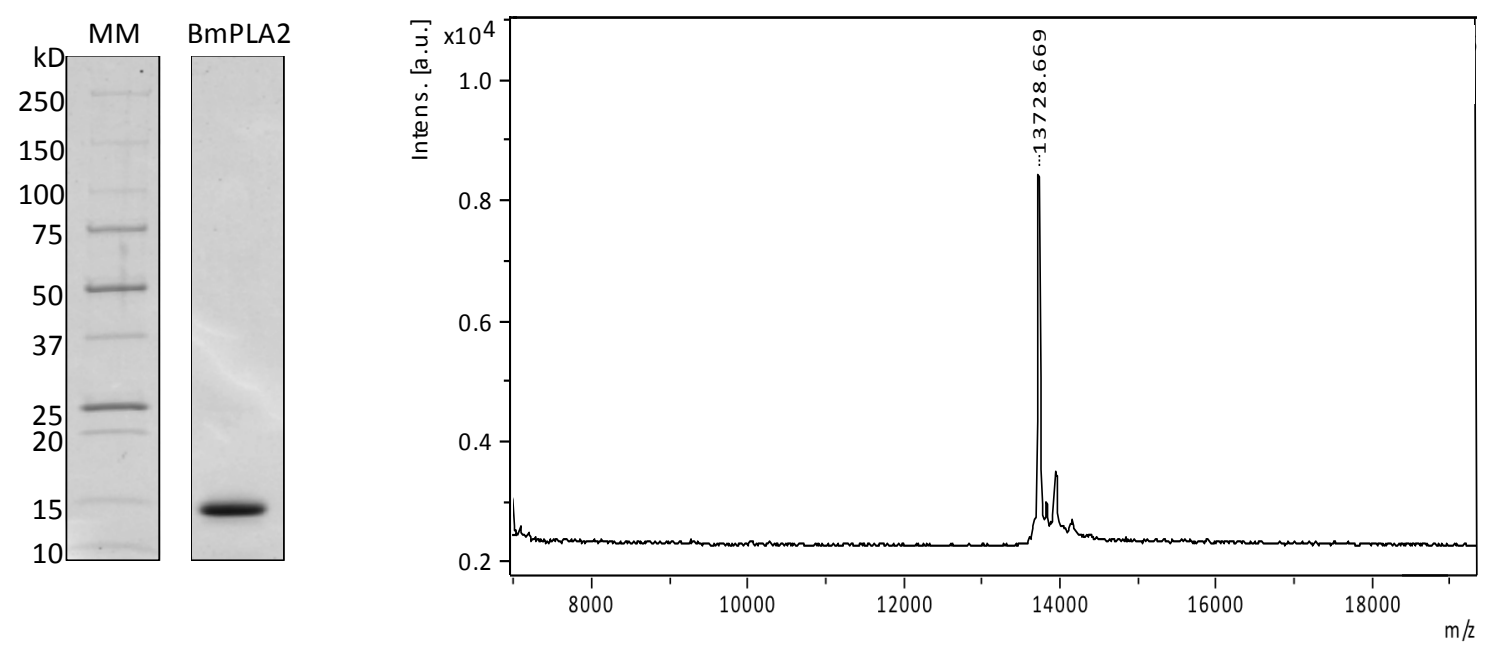

Figura 18| Purificação em coluna de fase reversa, avaliação do grau de homogeneidade e determinação da massa molecular da BmPLA2 isolada da peçonha de B. marmoratus. A: Perfil cromatográfico obtido a partir do fracionamento em coluna de fase reversa $\mathrm{C}_{18}$. Para eluição foi empregado gradiente linear de acetonitrila com TFA $0,1 \%$ (v/v) e fluxo de $1 \mathrm{~mL} / \mathrm{min}$. 0 monitoramento foi realizado a $216 \mathrm{~nm}$ e $280 \mathrm{~nm}$. Em vermelho está destacada a fração que corresponde a BmPLA2. B: Avaliação do grau de homogeneidade por SDS-PAGE da fração contendo a BmPLA2. Na primeira coluna, os padrões de massa molecular e na segunda, a fração correspondente a BmPLA2. C: Espectro de massa evidenciando a pureza da BmPLA2 e sua massa molecular, $[\mathrm{M}+\mathrm{H}]^{+}=13.728,66$.

\subsection{EFEITO CITOTÓXICO DA BMPLA2 E DETERMINAÇÃO DO IC 50 .}

O ensaio de viabilidade celular pelo método do MTT indicou que a fosfolipase A2 isolada da peçonha de $B$. marmoratus causa a redução da viabilidade celular de 
células HeLa após 24 horas de tratamento. Foi utilizada uma curva com concentrações crescentes de 0 a $250 \mu \mathrm{g} / \mathrm{mL}$ ou 18,2 $\mu \mathrm{M}$. A viabilidade celular foi reduzida mesmo em concentrações baixas da toxina e ocorreu de maneira dosedependente. $\mathrm{O} \mathrm{IC}_{50}$ relativo determinado foi de 8,7 $\pm 0,9 \mu \mathrm{M}$ (Figura 19).

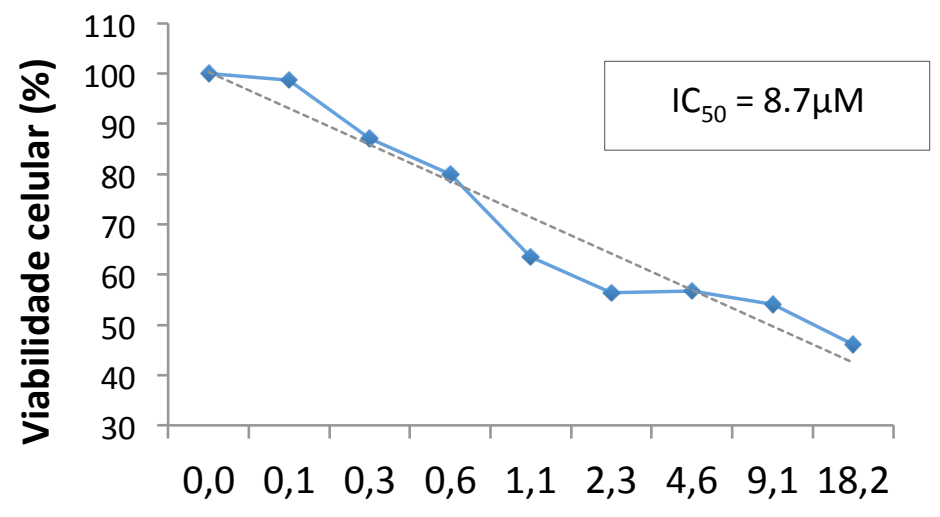

Concentração de BmPLA2 ( $\mu \mathrm{M})$

Figura 19| Diminuição da viabilidade celular causada pelo tratamento com a BmPLA2 por 24h. 0 ensaio foi realizado com células HeLa (câncer do colo do útero humano), de acordo com o método do MTT e está apresentado como a média dos valores obtidos em triplicata. 0 IC $_{50}$ relativo foi calculado utilizando-se o software GraphPad Prism 5.

\subsection{AVALIAÇÃO DA EXPRESSÃO GÊNICA DE CÉLULAS HeLa TRATADAS COM A BmPLA2}

Os níveis de expressão gênica das células tratadas ou não por diferentes tempos com a BmPLA2 também foram avaliados. Apesar de 53.617 transcritos terem sido detectados por microarranjo, apenas 1.964 genes foram identificados pelo programa DAVID Bioinformatic Resources e usados nas análises posteriores. Nas células tratadas por 2, 12 e 24 horas, 1.549, 700 e 526 genes, respectivamente, foram identificados como diferencialmente expressos, ou seja, com um fold change maior que 1.5 ou menor que 0.5 .

Os resultados indicam que as maiores alterações ocorrem nas horas iniciais do tratamento (Figura 20). Células tratadas por 2 horas apresentam pelo menos 2 vezes mais alterações na expressão gênica quando comparadas com células tratadas por 24 horas. É possível perceber também que a maioria dos genes sofreram alterações em torno de 1,5 vezes, enquanto genes com alterações maiores, acima de 
3 vezes, são menos frequentes. Esse dado é importante, uma vez que proteínas presentes nas células em baixas quantidades geralmente desempenham um papel importante no seu funcionamento, incluindo a sinalização e regulação da expressão gênica.

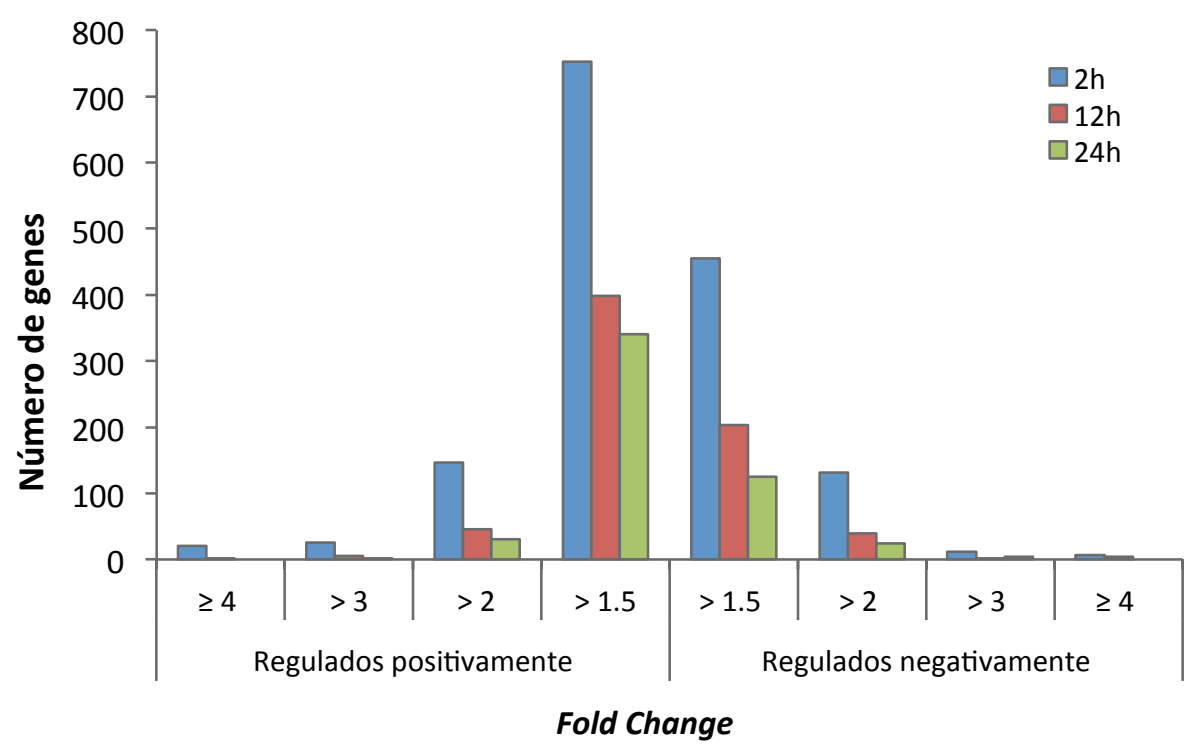

Figura 20| Genes identificados como diferencialmente expressos em células tratadas com a BmPLA2 por $2 \mathrm{~h}, 12 \mathrm{~h}$ ou $24 \mathrm{~h}$ totalizando 1.964 genes.

Padrões específicos de expressão gênica são comumente utilizados para caracterizar e correlacionar diferentes tipos de células e eventos celulares. Os perfis de expressão gênica de células HeLa tratadas por diferentes tempos com a BmPLA2 produziram um padrão diferenciado de acordo com o tempo de tratamento, permitindo assim a correlação desses perfis.

0 resultado da análise pelo software dChip mostra que o perfil de expressão gênica das células tratadas por 24 horas é mais similar ao grupo controle do que o perfil de células tratadas por 2 e 12 horas (Figura 21). Além disso, é possível notar a presença de grupos de genes expressivamente alterados nas horas iniciais, e que retornam a um padrão similar ao controle (nível basal) após 24 horas. Assim, sugere-se que as mudanças de expressão gênica mais drásticas ocorrem nas primeiras horas, e ao longo do tempo esse perfil demonstra uma aproximação do estado não tratado. 

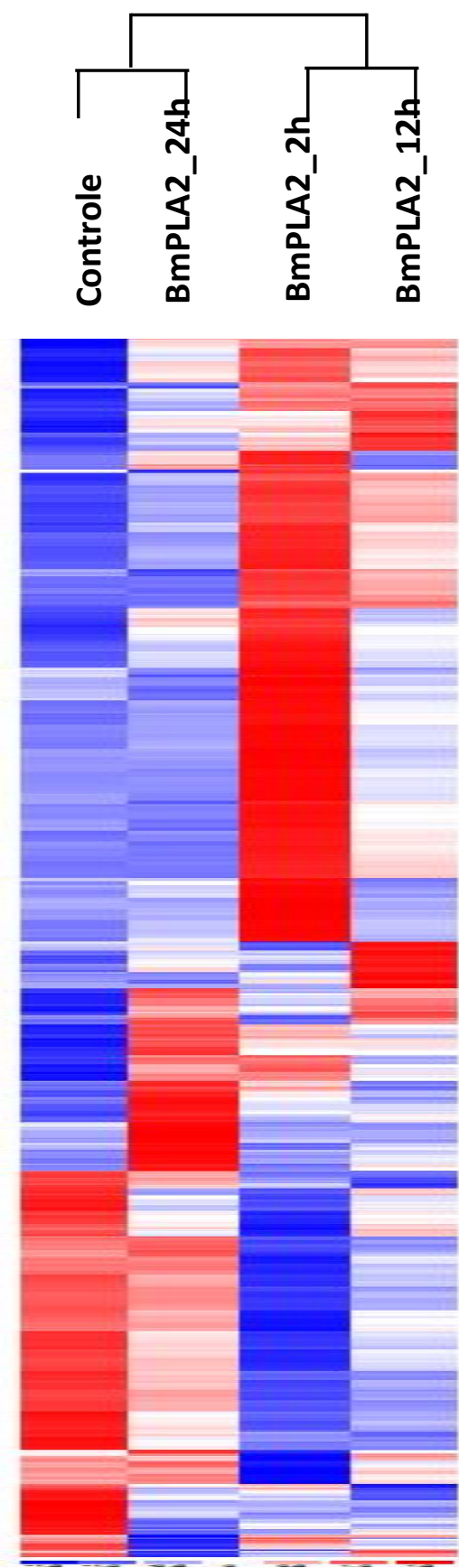

Figura 21| Perfil de expressão gênica de células HeLa tratadas por diferentes tempos com a BmPLA2. Agrupamento hierárquico da expressão de dados de expressão no GeneChip. As cores representam uma escala relativa ao nível de expressão que vai do vermelho, representando genes superexpressos até a cor azul, que representa genes subexpressos.

Nessa primeira etapa, a análise da expressão gênica permitiu relacionar os diferentes perfis produzidos e correlacionar as alterações produzidas ao longo do tempo. Em um segundo momento, os resultados foram avaliados quanto ao seu significado biológico, ou seja, os genes alterados foram agrupados de acordo com seu envolvimento em uma mesma via biológica, podendo assim indicar alguns dos efeitos causados pelo tratamento com a BmPLA2. 
A análise dos dados pelo programa DAVID Bioinformatic Resources, utilizando o banco de dados KEGG pathway, mostrou que diversas vias biológicas foram alteradas. Na tabela 2, destacamos algumas das vias alteradas e a quantidade de genes pertencentes a cada uma delas. Quanto menor o valor-p, mais enriquecida está determinada via, ou seja, mais genes envolvidos nesta via encontravam-se alterados. Normalmente o valor-p igual ou menor do que 0,05 é considerado fortemente enriquecido.

Tabela 2| Principais vias biológicas alteradas em células HeLa tratadas com a BmPLA2 a partir dos dados obtidos pela análise transcriptômica. A busca pelas vias foi realizada utilizando o banco de dados KEGG pathway.

\begin{tabular}{|lcc|}
\hline Via & \#Genes* & Valor-p \\
\hline Interação receptor citocina-citocina & 38 & $2.2 \mathrm{E}-5$ \\
Vias em câncer & 35 & $1,2 \mathrm{E}-2$ \\
Via de sinalização MAPK & 32 & $3.1 \mathrm{E}-3$ \\
Adesão focal & 23 & $2.2 \mathrm{E}-2$ \\
Regulação do citoesqueleto de actina & 21 & $2,3 \mathrm{E}-2$ \\
Via de sinalização Jak-STAT & 23 & $9.9 \mathrm{E}-4$ \\
Via de sinalização Wnt & 15 & $5 \mathrm{E}-2$ \\
Via de sinalização p53 & 12 & $6.8 \mathrm{E}-3$ \\
Apoptose & 23 & $2.2 \mathrm{E}-2$ \\
Interação receptor-ECM & 10 & $5 \mathrm{E}-2$ \\
\hline
\end{tabular}

* Para essa análise foram utilizadas apenas genes com fold change $\geq 1,5$ ou $\leq 0,5$.

Sabe-se que a via de sinalização MAPK controla a atividade gênica e está relacionada à regulação da expressão de diversas proteínas envolvidas no controle da proliferação celular, diferenciação e apoptose (Peyssonnaux \& Eychène 2001). Em mamíferos, essa via pode ser subdividida em quatro grupos, que são ativados em resposta a estímulos distintos. A via ERK é ativada em resposta a fatores mitogênicos e de crescimento, a via JNK é ativada principalmente por estresse celular e citocinas, a via p38 é uma das mais diversas e pode ser ativada em resposta a uma variedade de citocinas inflamatórias, agentes patogênicos, stress ambiental, ou ainda por alguns agentes mitogênicos (Junttila, Li \& Westermarck, 2008). Por fim, a via ERK5 (MEK5) é uma das menos caracterizadas, mas sabe-se que é ativada por estímulos como estresse oxidativo e hiperosmolaridade (Nishimoto \& Nishida 2006). 0 tratamento com a BmPLA2 ativou genes relacionados às 3 primeiras vias (ERK, JNK e p38), como é apontado na figura 22. 


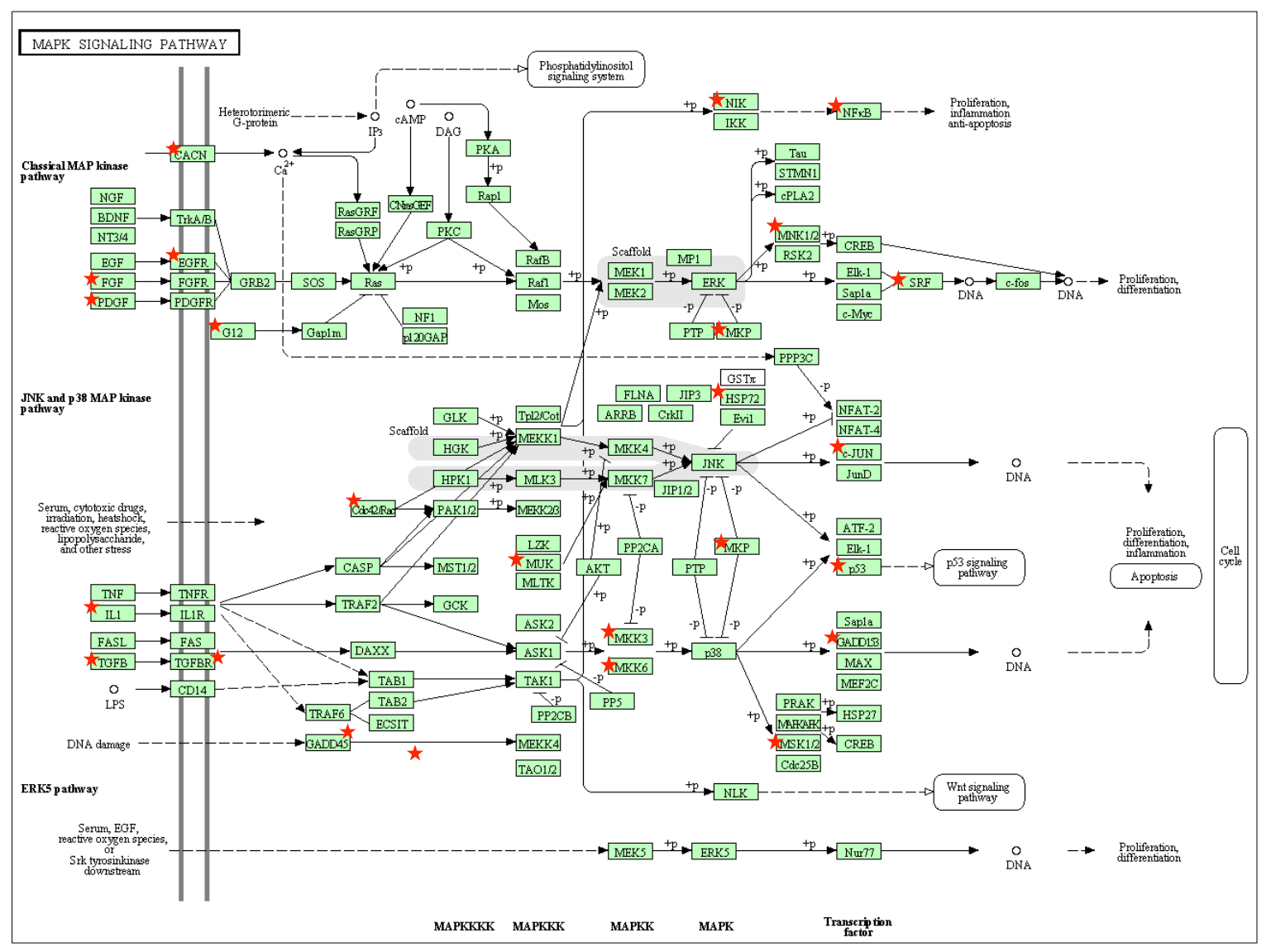

Figura 22| Via MAPK com marcação dos genes alterados em células HeLa tratadas por diferentes tempos com BmPLA2. Os genes que sofreram alteração nos níveis de expressão são sinalizados com uma estrela vermelha. Figura gerada utilizando o banco de dados KEGG pathway.

0 gene GADD45B, por exemplo, é um membro de um grupo de genes cujos níveis de transcrição aumentam após estresse e dano ao DNA, seguido por parada do crescimento celular. Sua função está portanto envolvida na regulação do crescimento e apoptose. Nota-se que com o tratamento realizado, a expressão desse gene foi aumentada após 2 horas, seguida por um decaimento brusco após $12 \mathrm{~h}$ e por fim, sendo hipoexpresso após 24 horas (Figura 23).

Outra família de genes alterados foram os que codificam as fosfatases de dupla especificidade (DUSP ou MKP). Trata-se de uma família de genes que atuam basicamente na regulação da via MAPK desfosforilando outras proteínas pertencentes a essa via e fazendo com que sua atividade retorne ao nível basal (Camps, Nichols \& Arkinstall, 2000). Os níveis de fosfatases de dupla especificidade em tumores são geralmente elevados em estágios iniciais, porém podem estar 
hiporegulados em tumores invasivos (Keyse 2008). Nesse estudo, células HeLa tratadas com a BmPLA2 hiperexpressaram genes pertencentes a esta família nas horas iniciais, sendo reduzidos após 12 e 24 horas.

O gene DUSP9 foi o único que apresentou um padrão diferente, tendo sido hipoexpresso em 2 horas e retornando aos níveis basais em seguida. Esse gene tem sido mais estudado e bem caracterizado em tecidos extraembrionários (Li et al., 2007), porém um estudo utilizando análise de mRNA por Affymetrix GeneChip, mostrou que esse gene encontra-se hiporegulado em um modelo de carcinogênese epitelial e experimentos de recontituição mostraram que sua reexpressão levou ao aumento da morte celular (Liu et al., 2007).

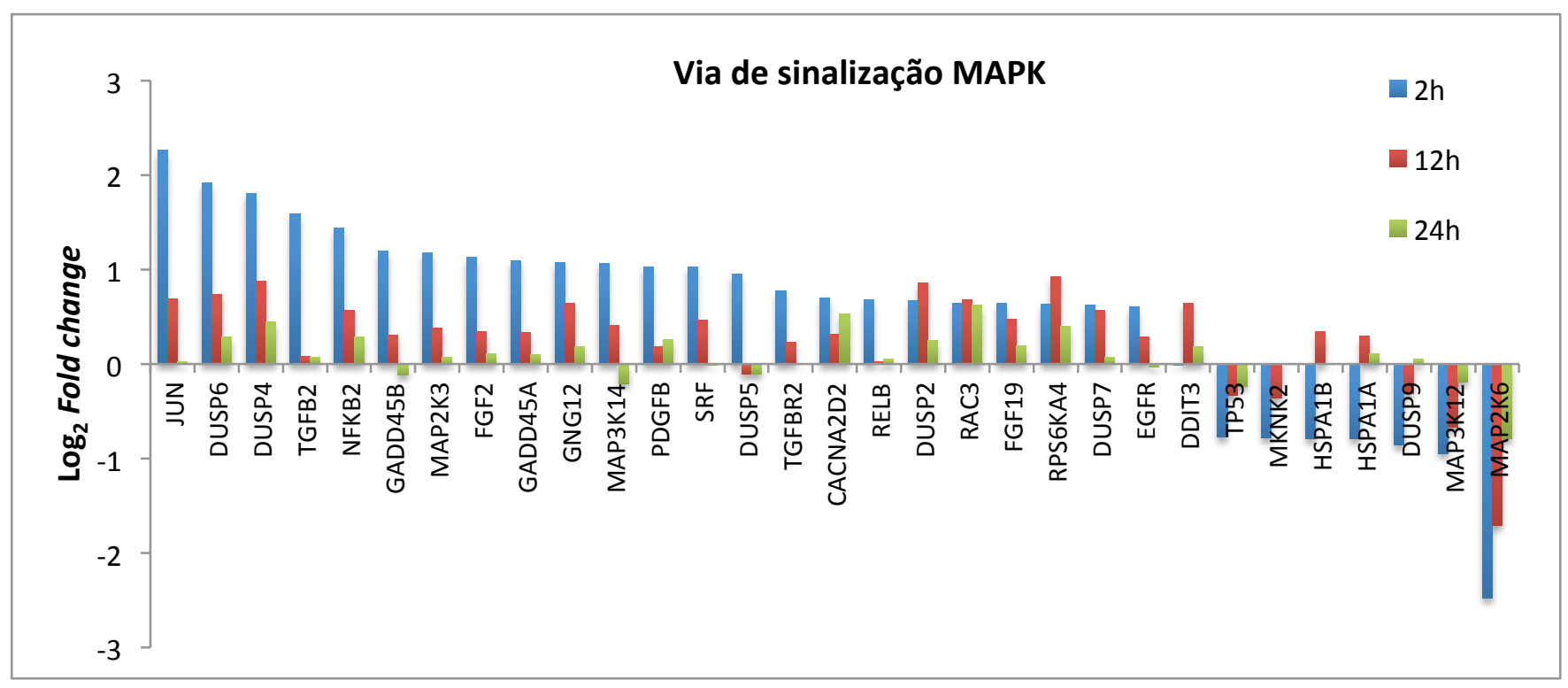

Figura 23| Mudança na expressão de genes relacionados à via de sinalização MAPK em células HeLa tratadas por diferentes tempos com a BmPLA2. Os dados apresentados são o $\log _{2}$ da mudança em relação ao controle. As vias metabólicas foram identificadas utilizando DAVID Bioinformatics Resources 6.7.

Dois genes da família heat shock, HSPA1A e HSPA1B, foram alterados após o tratamento com a BmPLA2. Os produtos desses genes pertencem à família de proteínas heat shock de $70 \mathrm{kDa}$, e estabilizam proteínas contra a agregação, além de mediar o enovelamento de outras recém-traduzidas (Cloutier, Lavallée-Adam, Faubert, Blanchette, \& Coulombe, 2013). Também bloqueiam a apoptose por meio da ligação com Apaf-1, evitando a formação e ativação do apoptossomo (complexo Apaf-1/ citocromo c/ caspase-9) e com o fator indutor de apoptose (AIF) (Ravagnan et al. 2001). Assim como a hiperexpressão dessa proteína pode proteger células 
contra a morte celular induzida por fatores externos como a luz ultravioleta (Simon et al. 1995), aqui a hipoexpressão seguida de hiper pode indicar um efeito tanto na via MAPK, na produção de proteínas, quanto na modulação da via apoptótica, protegendo as células contra o efeito da toxina.

Diversos genes relacionados à adesão focal, que atuam conectando o citoesqueleto de actina à fibras de fibronectina da ECM apresentaram alterações nos níveis de expressão após o tratamento com a BmPLA2 (figura 24). De maneira geral, é possível notar que esses genes encontram-se hiperexpressos 2 horas após o tratamento com a BmPLA2 e, apesar de decaírem após 12 e 24 horas, esse aumento inicial pode ter um efeito crucial na adesão e/ou morte celular.

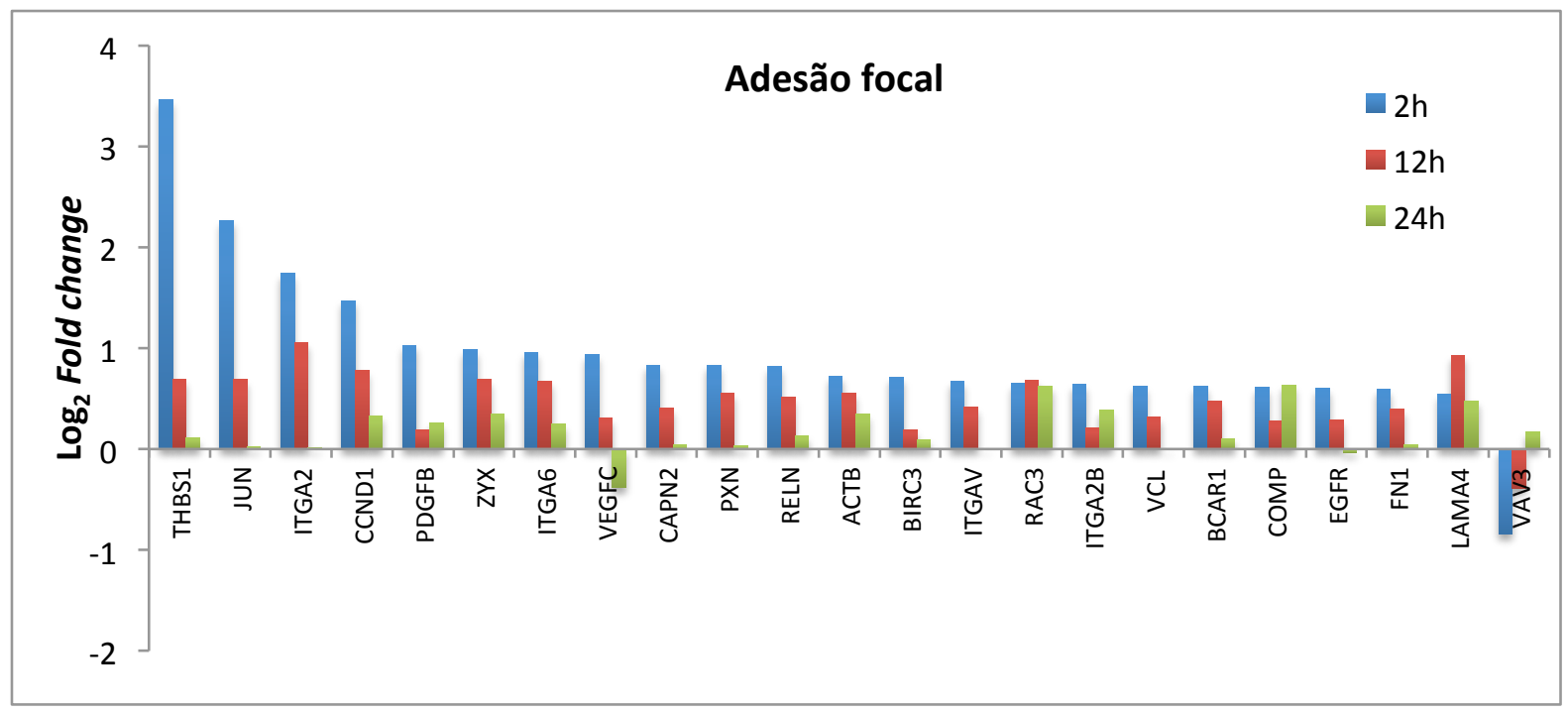

Figura 24| Mudança na expressão de genes relacionados à adesão focal em células HeLa tratadas por diferentes tempos com BmPLA2. Os dados apresentados são o $\log _{2}$ da mudança em relação ao controle. As vias metabólicas foram identificadas pelo DAVID utilizando o banco de dados KEGG PATHWAY .

Dentre os diversos genes alterados e que apresentaram um padrão similar, uma exceção é bem evidente. Trata-se do gene VAV3, um membro da família VAV que consistem em fatores de troca de nucleotídeos de guanina, responsáveis pela ativação de vias que levam a um rearranjo do citoesqueleto de actina e alterações transcricionais (Haataja, Groffen \& Heisterkamp, 1997). Diferentemente dos outros, VAV3 apresentou-se hipoexpresso após 2 horas de tratamento, sendo que esse efeito foi revertido após 24 horas. 
Outro tipo de morte celular programada bastante estudada é a apoptose. Sabe-se que esse mecanismo pode ser controlado geneticamente e envolve uma extensa lista de eventos que incluem o processamento e expressão de diversas proteínas. 0 tratamento das células HeLa com a BmPLA2 produziu diferentes alterações nos níveis de expressão em diversos genes relacionados à apoptose, como mostra a figura 25 .

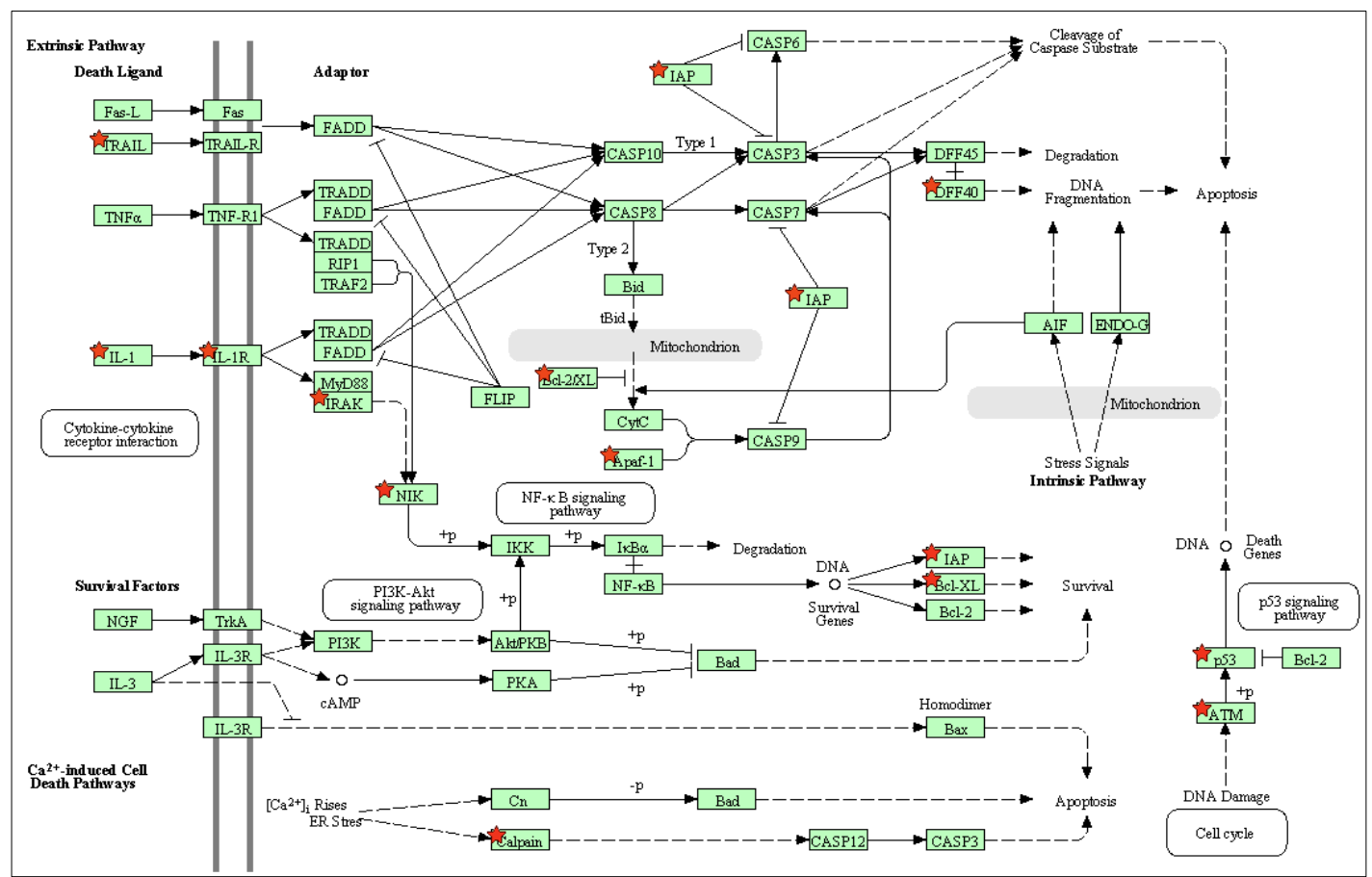

Figura 25| Via apoptótica com marcação dos genes alterados em células HeLa tratadas por diferentes tempos com a BmPLA2. Os genes que sofreram alteração nos níveis de expressão são sinalizados com uma estrela vermelha. Figura gerada utilizando o banco de dados KEGG pathway.

Os resultados obtidos e expressos em escala logarítmica, indicam que na fase inicial as células apresentam determinado padrão de alterações nos níveis de expressão gênica. Pode-se notar o aumento ou diminuição da expressão de diversos genes associados positiva ou negativamente à apoptose. Com o aumento do tempo de tratamento é possível notar uma diminuição nos níveis de expressão e, que 24 horas após o tratamento, já se encontram bem próximos dos níveis basais descritos para o grupo controle, ou até mesmo expressos negativamente (figura 26). 
Genes responsáveis pela produção das proteínas interleucina 1 alfa (IL1A), proteína quinase quinase quinase 14 ativada por mitógeno (MAP3K14), interleucina-1 associada ao receptor quinase 2 (IRAK2), calpaína 2 (CAPN2), proteína acessória do receptor de interleucina-1 (IL1RAP), fator de fragmentação do DNA (DFFB), proteína quinase similar à serina (ATM), proteína tumoral p53 (TRP53), o membro 10 da superfamília de receptor para o fator de necrose tumoral (TNFSF10), ou ainda o fator ativador da peptidase apoptótica 1 (APAF1) são proteínas relacionadas à indução da apoptose. Nota-se que esses genes não apresentam um perfil similar quanto aos níveis de expressão após o tratamento (Figura 26).

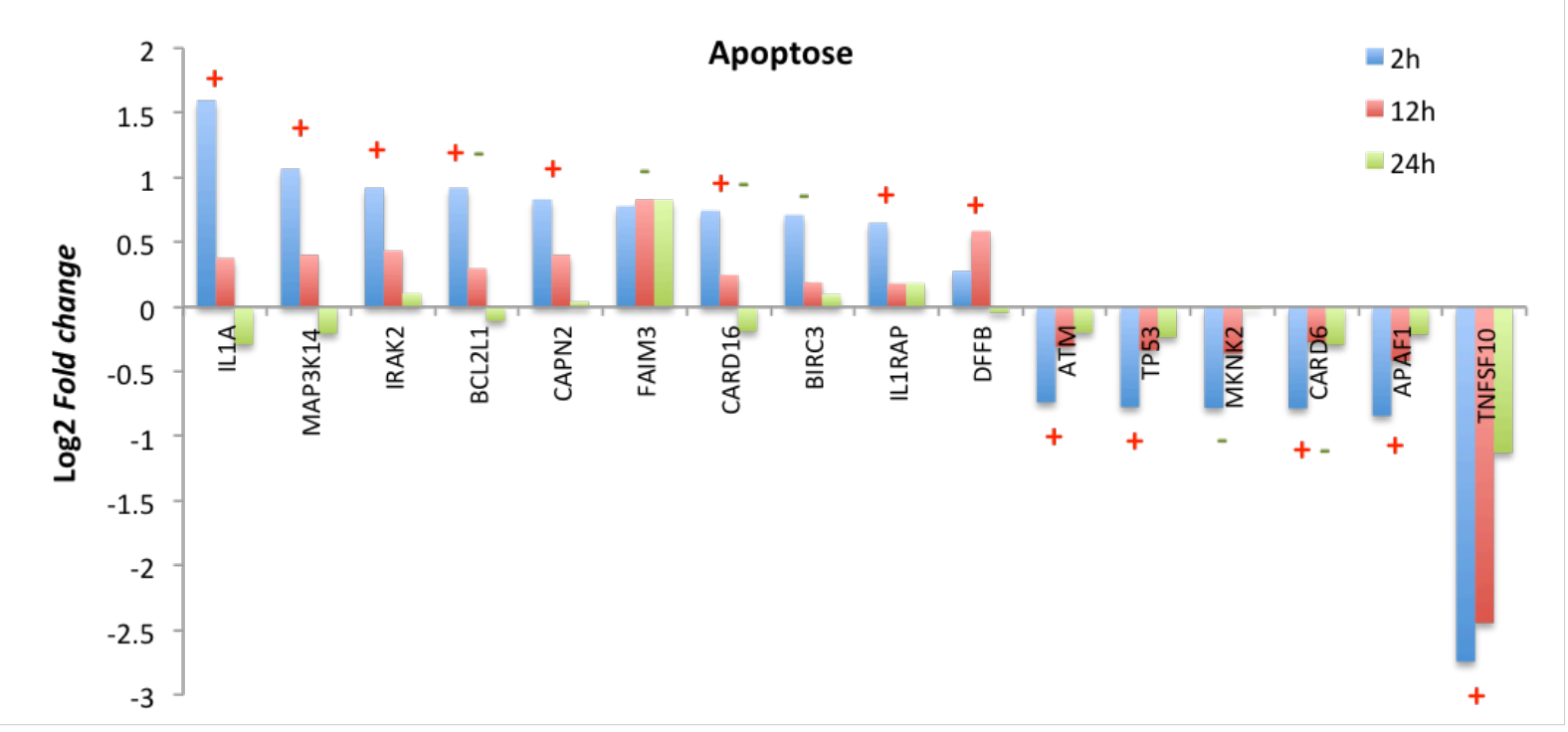

Figura 26| Mudança na expressão de genes relacionados à via apoptótica em células HeLa tratadas por diferentes tempos com BmPLA2. Os dados apresentados são o $\log _{2}$ da mudança em relação ao controle. As vias metabólicas foram identificadas utilizando DAVID Bioinformatics Resources 6.7. + sinaliza os genes envolvidos com a indução de apoptose. -, genes envolvidos com a inibição de apoptose e +- , genes que podem tanto induzir quanto inibir a apoptose.

A maioria deles pertencem exclusivamente à via extrínseca, com exceção do gene APAF1, componente central na formação do apoptossomo, um complexo multiproteico que, após a liberação do citocromo C pela mitocôndria, ativa a procaspase-9 na via intrínseca da apoptose (Li et al., 1997). Esse gene, como mostra a figura 26, mostrou-se hipoexpresso em todos os tempos testados, sendo estes níveis mais acentuados no tempo de 2 horas. 
Genes antiapoptóticos ou que desempenham ambos papéis, dependendo do momento celular, também foram encontrados com níveis de expressão alterados, como é o caso dos genes relativos à proteína reguladora da apoptose BCL-2 (BCL2L1), molécula 3 inibidora da Fas apoptótica (FAIM3), a família de domínios de recrutamento de caspases, membro 6 (CARD6) ou membro 16 (CARD16), a repetição IAP de baculovírus contendo a proteína 3 (BIRC3) ou ainda a serina/treonina quinase 2 de interação com MAP quinase (MKNK2). Como é possível visualizar na figura 26, esses genes também apresentam alterações mais expressivas em 2 horas, seja positiva ou negativamente, e tendem a se normalizar após 12 e 24 horas, com exceção de FAIM3 que permaneceu superexpresso por até 24 horas.

Exceções a esse padrão foram os genes DFFB e FAIM3. DFFB apresentou níveis de expressão elevados às 12 horas, porém, subexpresso após 24 horas. A transcrição desse gene produz uma nuclease que induz a fragmentação de DNA e condensação da cromatina durante a apoptose, induzindo a morfologia apoptótica (Liu et al., 1998). Por outro lado, o gene FAIM3, que tem como função proteger as células contra a apoptose induzida por FAS, TNF alfa e FADD (Hitoshi et al. 1998), permaneceu superexpresso mesmo após 12 e 24 horas do tratamento.

Embora autofagia possa promover a sobrevivência de células (Codogno \& Meijer 2005), ela também pode ser considerada um mecanismo "à prova de falhas" em condições nas quais a apoptose falha por algum motivo. Assim, a morte celular pode ocorrer de forma apoptótica, sendo acompanhada por autofagia ou de forma não apoptótica e dependendo exclusivamente de genes ligados à autofagia (Shimizu et al. 2004).

Diferentes proteínas envolvidas na formação dos autofagossomos podem ser detectadas por Western Blot. As mais utilizadas são divididas em duas subfamílias: LC3 (proteína associada a microtúbulos 1 cadeia leve 3 ), que é associada à formação do fagoforo e GABARAP (proteína associada ao receptor $\mathrm{GABA}_{\mathrm{A}}$ ), que pode ser encontrada em fases posteriores da formação autofagosomo, em particular nos processos de alongamento e encerramento das vesículas (Klionsky, DJ 2012).

0 gene MAP1LC3B2, que expressa a proteína LC3, foi encontrado ligeiramente hiperexpresso após 2 horas de tratamento com a BmPLA2, porém, hipoexpresso após 12 e 24 horas. Já o gene GABARAPL1 apresentou-se 
hiperexpresso em 2 horas, e sua expressão decaiu exponencialmente após 12 e 24 horas (figura 27).

Interferons também estão envolvidos com a autofagia. Diversos estudos recentes mostram interferons do tipo I induzindo autofagia em diferentes linhagens celulares (Schmeisser et al. 2013; Ambjørn et al. 2013), além de estarem relacionados à resposta inflamatória e ativação da imunidade (Jounai et al., 2007; Delgado \& Deretic, 2009). Alguns destes genes encontram-se sobretudo hiperexpressos em células tratadas por 2 horas, como pode ser notado na figura 27.

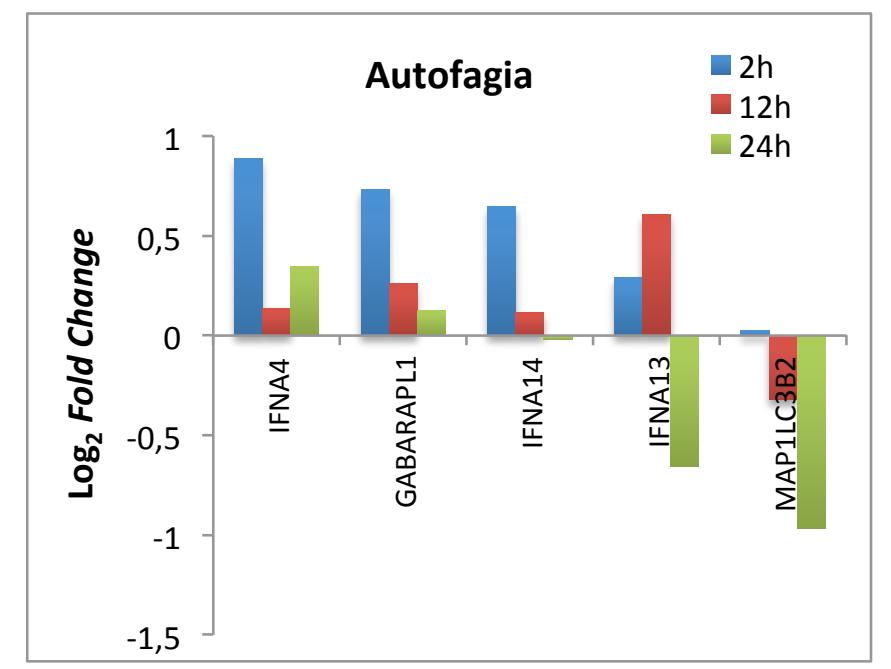

Figura 27| Mudança na expressão de genes relacionados à autofagia em células HeLa tratadas por diferentes tempos com a BmPLA2. Os dados apresentados são o $\log _{2}$ da mudança em relação ao controle. As vias metabólicas foram identificadas pelo DAVID utilizando o banco de dados KEGG PATHWAY.

\subsection{ANÁLISE PROTEÔMICA DE CÉLULAS HeLa tratadas com a BmPLA2}

Além da avaliação da expressão gênica por microarranjo, a análise proteômica da cultura celular tratada ou não com a BmPLA2 por 24 horas também foi realizada. As células foram tratadas por 24 horas na concentração equivalente ao $\mathrm{IC}_{50}$ para esse tipo celular, lisadas e as proteínas extraídas e precipitadas. 0 gel desnaturante SDS-PAGE desse extrato celular revelou que a composição do extrato obtido das células tratadas em comparação com células não tratadas com a PLA2 possuem perfis similares (Figura 28). 
A análise proteômica foi realizada com cada uma das 10 bandas extraídas do gel e o valor quantitativo de cada proteína identificada foi analisado. Proteínas com um fold change $\geq 1,5$ ou $\leq 0,5$ respectivamente aumentados ou diminuídos, foram considerados relevantes para análise de alteração de processos biológicos e vias metabólicas.

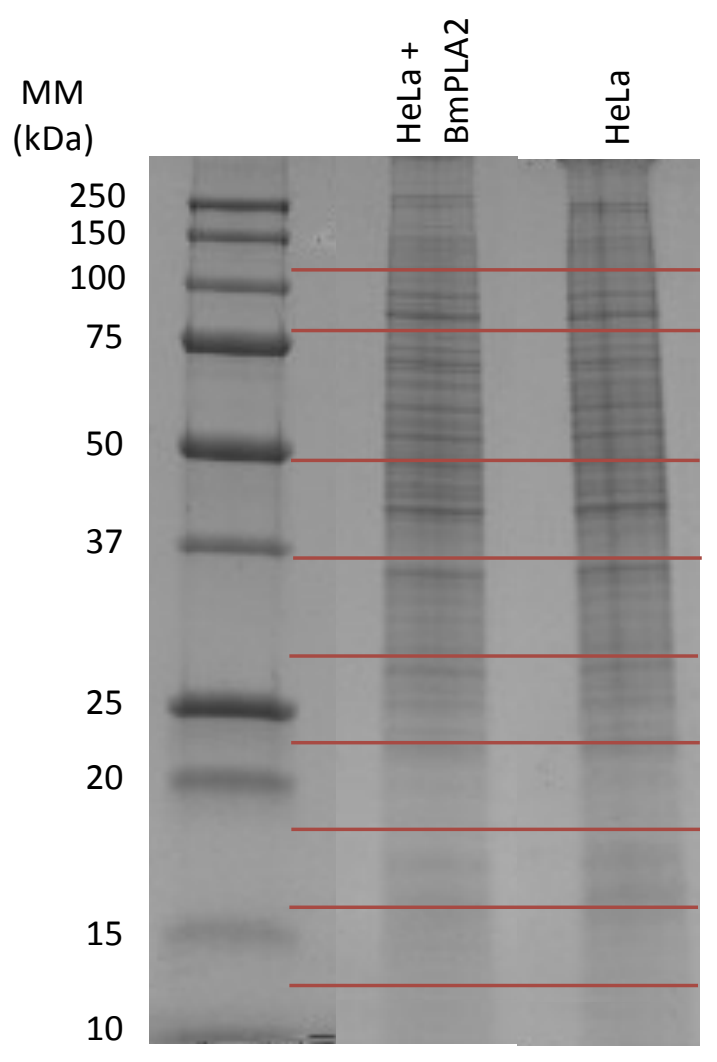

Figura 28| Gel desnaturante SDS-PAGE do extrato de células (HeLa) tratadas na concentração equivalente ao IC $_{50}$ da BmPLA2 ou com salina por $24 \mathrm{~h}$. Após a extração de proteínas, as amostras $(20 \mu \mathrm{g})$ foram submetidas a eletroforese em gel pré-moldado Any$\mathrm{kD}^{\mathrm{TM}}$ Criterion $^{\mathrm{TM}} \mathrm{TGX}^{\mathrm{TM}}$ (Bio-Rad), posteriormente corado com Coomassie Brilliant Blue. As linhas vermelhas assinalam o local em que as bandas foram cortadas para posterior análise por LC-MS/MS.

0 número de proteínas identificadas com pelo menos 2 peptídeos neste experimento foi de 4.459, sendo 857 com um fold change considerado relevante e 714 identificadas pelo DAVID e utilizadas para as análises de Gene Ontology e Pathways. É possível notar que algumas são encontradas em níveis muito similares aos valores encontrados no grupo controle, enquanto outras possuem valores bem diferentes. Essas proteínas diferencialmente expressas estão correlacionadas a diferentes demandas biológicas como processos de defesa, morte celular e 
manutenção da homeostasia, entre outros, que foram em seguida analisados com o auxílio de diferentes softwares.

O diagrama de dispersão quantitativo dado pelo programa Scaffold e apresentado na figura 29, mostra a quantidade de espectros normalizados de cada proteína como um ponto. 0 eixo x é a contagem de espectros para as proteínas provindas de células tratadas com BmPLA2 enquanto o eixo y é a contagem de espectros para as amostras não tratadas. Proteínas com abundâncias similares em ambas amostras biológicas são traçadas perto da linha de tendência. As proteínas plotadas mais distantes dessa linha são consideradas diferencialmente expressas. Com a análise desse gráfico, é possível perceber que as proteínas encontradas em pequenas quantidades nas células, são as que sofrem alterações mais significativas e são portanto as que podem estar mais envolvidas com a resposta da célula ao tratamento com a BmPLA2

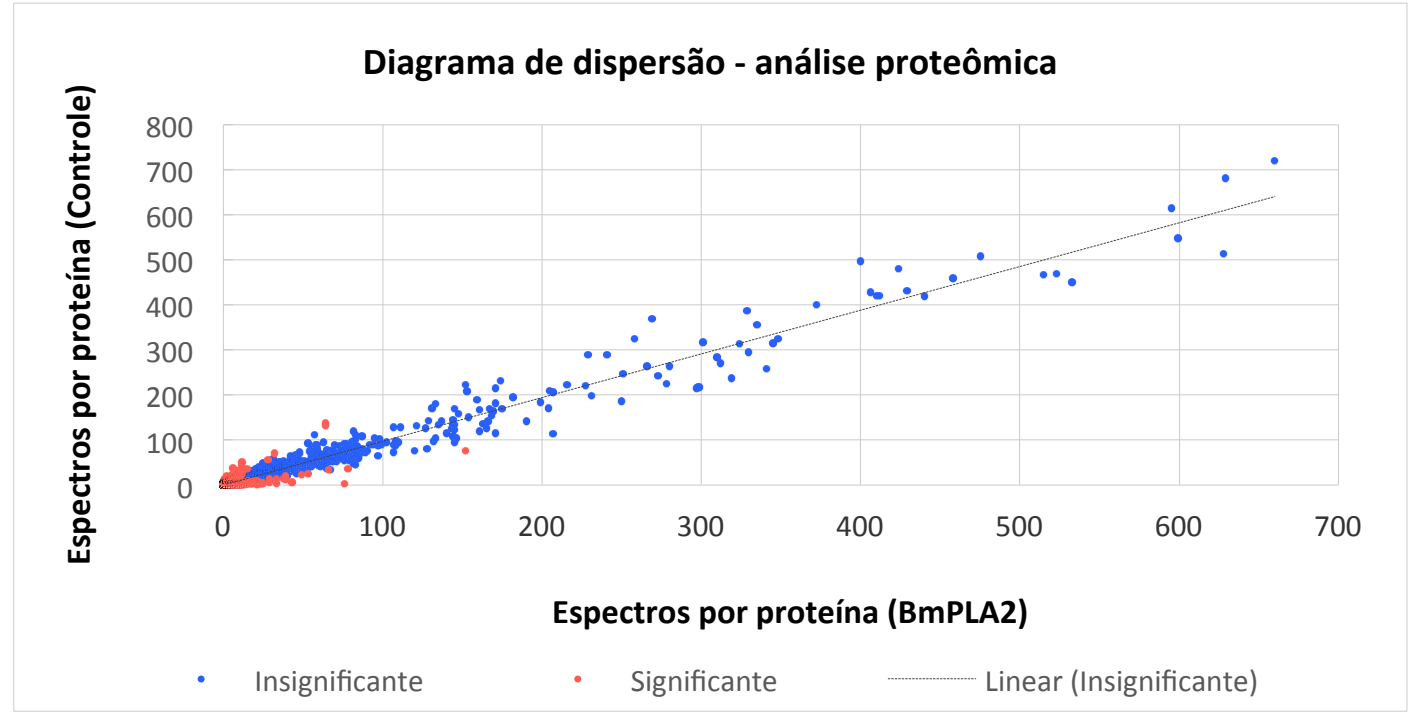

Figura 29| Diagrama de dispersão das proteínas identificadas por LC-MS. Os eixos mostram a quantidade de espectros contados para cada proteína provindos de células HeLa tratadas ou não com a BmPLA2. Os pontos vermelhos representam proteínas sinalizadas como diferencialmente expressas por qualquer teste estatístico (fold change, coeficiente de variação, teste T, ANOVA), enquanto os azuis são sinalizados como não significativos.

Diversas vias metabólicas foram alteradas nas células tratadas. Entre elas, destacam-se processos relacionados à síntese de proteínas, ciclo celular e resposta a danos (Tabela 3). Quanto menor o valor-p, mais enriquecida está determinada via, 
ou seja, mais genes correlacionados a esta via foram alterados. Normalmente o valor-p igual ou menor do que 0,05 é considerado fortemente enriquecido. Esses resultados possibilitam uma visão geral sobre o estado da célula, bem como dos processos biológicos em destaque naquele momento.

Tabela 3| Principais vias biológicas alteradas em células HeLa tratadas com a BmPLA2 a partir dos dados obtidos pela análise proteômica. A busca pelas vias foi realizada utilizando o banco de dados KEGG pathway.

\begin{tabular}{|lcc|}
\hline Via & \# Proteínas & Valor P \\
\hline Spliceossoma & 20 & $6.4 \mathrm{E}-6$ \\
Metabolismo de purina & 19 & $3.2 \mathrm{E}-4$ \\
Endocitose & 15 & $5.6 \mathrm{E}-2$ \\
Metabolismo de pirimidina & 14 & $5.2 \mathrm{E}-4$ \\
Fosforilação oxidativa & 13 & $2.1 \mathrm{E}-2$ \\
Degradação de RNA & 11 & $3.1 \mathrm{E}-4$ \\
Replicação de DNA & 7 & $6.5 \mathrm{E}-3$ \\
Reparo por excisão de nucleotídeos & 7 & $1.7 \mathrm{E}-2$ \\
RNA polimerase & 6 & $9.5 \mathrm{E}-3$ \\
Reparo de incompatibilidade do DNA & 4 & $9.4 \mathrm{E}-2$ \\
(mismatch repair) & 3 & $5.3 \mathrm{E}-2$ \\
Exportação de proteínas & & \\
\hline
\end{tabular}

*Para essa análise foram utilizadas apenas proteínas com fold change $\geq 1,5$ ou $\leq 0,5$.

Como já foi citado, diversos processos biológicos foram alterados e puderam ser identificados através do estudo proteômico. Na tabela 4, destacamos apenas as proteínas significativamente alteradas que participam de qualquer uma das vias relacionadas à morte celular por apoptose, anoikis ou autofagia, vias estas já discutidas anteriormente.

Entre essa lista, podemos encontrar proteínas altamente modificadas quanto aos níveis de expressão, como é o caso da clusterina, lisozima e EGFR, reguladas positivamente, ou ainda reticulon 3, Proteína quinase 1 ativada por mitose e o inibidor de metaloprotease 3 TIMP que encontravam-se subexpressas nas células tratadas. Todas, exercendo funções chave nessas vias. 
Tabela 4| Proteínas relacionadas à morte celular, adesão focal e autofagia com alteração considerada significativa. Resultados obtidos por análise proteômica de células HeLa tratadas com BmPLA2 por 24 horas.

\begin{tabular}{|c|c|c|}
\hline \multicolumn{3}{|c|}{ Morte celular } \\
\hline Acesso* & Proteína & $\begin{array}{l}\text { Fold } \\
\text { Change }\end{array}$ \\
\hline P10909 & Clusterin & 7,5 \\
\hline P61626 & Lysozyme & 6,6 \\
\hline P00533 & Epidermal growth factor receptor & 6 \\
\hline Q9Y2A7 & NCK-associated protein 1 & 6 \\
\hline P10586 & Protein tyrosine phosphatase, receptor type, F & 4 \\
\hline P11388 & Topoisomerase (DNA) II alpha 170kda & 3,5 \\
\hline P08243 & Asparagine synthetase & 3 \\
\hline Q8WYA6 & Catenin, beta like 1 & 3 \\
\hline Q14318 & FK506 binding protein $8,38 \mathrm{kda}$ & 2,67 \\
\hline Q5VY93 & Rho/Rac guanine nucleotide exchange factor (GEF) 2 & 2,5 \\
\hline Q9UHX1 & Poly-U binding splicing factor $60 \mathrm{kda}$ & 2,23 \\
\hline Q99700 & Ataxin 2 & 2 \\
\hline Q96KA5 & CLPTM1-like & 2 \\
\hline Q9NR28 & Diablo homolog (Drosophila) & 2 \\
\hline P50570 & Dynamin 2 & 2 \\
\hline Q9BX68 & Histidine triad nucleotide binding protein 2 & 2 \\
\hline Q13564 & NEDD8 activating enzyme E1 subunit 1 & 2 \\
\hline P07858 & Cathepsin B & 0,5 \\
\hline Q9UHI6 & DEAD (Asp-Glu-Ala-Asp) box polypeptide 20 & 0,5 \\
\hline Q9H2J4 & Phosducin-like 3 pseudogene; phosducin-like 3 & 0,5 \\
\hline Q53EL6 & Programmed cell death 4 (neoplastic transformation inhibitor) & 0,5 \\
\hline 060216 & RAD21 homolog (S. Pombe) & 0,5 \\
\hline Q01085 & TIA1 cytotoxic granule-associated RNA binding protein-like 1 & 0,5 \\
\hline Q5J8M3 & Transmembrane protein 85 & 0,5 \\
\hline Q13616 & Cullin 1 & 0,33 \\
\hline Q13232 & Non-metastatic cells 3 , protein expressed in & 0,33 \\
\hline Q53GA4 & Pleckstrin homology-like domain, family A, member 2 & 0,33 \\
\hline Q969Z0 & Transforming growth factor beta regulator 4 & 0,33 \\
\hline 095197 & Reticulon 3 & 0,31 \\
\hline P28482 & Mitogen-activated protein kinase 1 & 0,27 \\
\hline Q8N0X7 & Spastic paraplegia 20 (Troyer syndrome) & 0,2 \\
\hline P35625 & TIMP metallopeptidase inhibitor 3 & 0,125 \\
\hline \multicolumn{3}{|l|}{ Adesão } \\
\hline Acesso* & Proteína & $\begin{array}{l}\text { Fold } \\
\text { Change }\end{array}$ \\
\hline P15924 & Desmoplakin & 2,5 \\
\hline Q5VY93 & Rho/Rac guanine nucleotide exchange factor (GEF) 2 & 2,5 \\
\hline 015061 & Synemin, intermediate filament protein & 2,0 \\
\hline P50552 & Vasodilator-stimulated phosphoprotein & 2,0 \\
\hline P50570 & Dynamin 2 & 2,0 \\
\hline P23229 & Integrin, alpha 6 & 0,5 \\
\hline
\end{tabular}


P31151 S100 calcium binding protein A7

Q9UDY2 Tight junction protein 2 (zona occludens 2) 0,5

Q9H307 Pinin, desmosome associated protein 0,4

095295 SNAP-associated protein 0,4

$\begin{array}{ll}\text { Q9UGI8 Testis derived transcript (3 LIM domains) } & 0,3\end{array}$

$\begin{array}{lll}\text { Q8N8S7 } & \text { Enabled homolog (Drosophila) } & 0,3\end{array}$

$\begin{array}{ll}\text { P06703 S100 calcium binding protein A6 } & 0,2\end{array}$

\begin{tabular}{|lll|}
\hline Autofagia & & \\
\hline Acesso* & Proteína & Fold \\
& & Change \\
\hline Q3ZAQ7 & VMA21 vacuolar H+-atpase homolog (S. Cerevisiae) & 2,50 \\
P07858 & Cathepsin B & 0,50 \\
\hline
\end{tabular}

* Banco de dados Uniprot (UniProtKB)

Algumas proteínas no entanto, não foram identificadas no grupo controle, mas estavam presentes nas células tratadas ou vice-versa, não sendo possível calcular o fold change. Nestes casos, o valor quantitativo de cada proteína calculado pelo programa scaffold foi representadas como $0 \rightarrow \mathrm{X}$, ou $\mathrm{X} \rightarrow 0$, respectivamente, sendo $\mathrm{X}$ o valor quantitativo encontrado (tabela 5).

Tabela 5| Proteínas relacionadas à morte celular e adesão focal ausentes em uma das amostras e presente em outra. Resultados obtidos por análise proteômica de células HeLa tratadas com BmPLA2 por 24 horas.

\begin{tabular}{|lll|}
\hline Morte celular & \\
\hline Acesso* & Proteína & $\begin{array}{l}\text { Valor } \\
\text { quantitativo }\end{array}$ \\
\hline Q969U7 & Proteasome (prosome, macropain) assembly chaperone 2 & $0 \rightarrow 3$ \\
Q96FV9 & THO complex 1 & $0 \rightarrow 3$ \\
P48506 & Glutamate-cysteine ligase, catalytic subunit & $0 \rightarrow 2$ \\
P49841 & Glycogen synthase kinase 3 beta & $0 \rightarrow 2$ \\
O43464 & Htra serine peptidase 2 & $0 \rightarrow 2$ \\
P49917 & Ligase IV, DNA, ATP-dependent & $0 \rightarrow 2$ \\
P47712 & Phospholipase A2, group IVA (cytosolic, calcium-dependent) & $0 \rightarrow 2$ \\
P51159 & RAB27A, member RAS oncogene family & $0 \rightarrow 2$ \\
Q9NY61 & Apoptosis antagonizing transcription factor & $3 \rightarrow 0$ \\
Q9UL15 & BCL2-associated athanogene 5 & $2 \rightarrow 0$ \\
Q8IX12 & Cell division cycle and apoptosis regulator 1 & $2 \rightarrow 0$ \\
P56199 & Integrin, alpha 1 & $3 \rightarrow 0$ \\
P04150 & Nuclear receptor subfamily 3, group C, member 1 & $3 \rightarrow 0$ \\
P56945 & Similar to breast cancer anti-estrogen resistance 1 & $4 \rightarrow 0$ \\
Q15628 & TNFRSF1A-associated via death domain & $2 \rightarrow 0$ \\
Q2TAM5 & V-rel reticuloendotheliosis viral oncogene homolog A (avian) & $2 \rightarrow 0$ \\
\hline
\end{tabular}




\begin{tabular}{|lll|}
\hline Adesão & & \\
\hline Acesso* & Proteína & $\begin{array}{l}\text { Valor } \\
\text { quantitativo }\end{array}$ \\
\hline Q03135 & Caveolin 1, caveolae protein, 22kda & $0 \rightarrow 6$ \\
Q13425 & Syntrophin, beta 2 & $0 \rightarrow 3$ \\
Q99720 & Sigma non-opioid intracellular receptor 1 & $0 \rightarrow 3$ \\
P49917 & Ligase IV, DNA, ATP-dependent & $0 \rightarrow 2$ \\
Q14145 & Kelch-like ECH-associated protein 1 & $0 \rightarrow 2$ \\
P06756 & Integrin, alpha V & $2 \rightarrow 0$ \\
P56199 & Integrin, alpha 1 & $3 \rightarrow 0$ \\
P56945 & Similar to breast cancer anti-estrogen resistance 1 & $2 \rightarrow 0$ \\
Q9Y446 & Plakophilin 3 & $2 \rightarrow 0$ \\
Q9Y624 & F11 receptor & $2 \rightarrow 0$ \\
\hline
\end{tabular}

* Banco de dados Uniprot (UniProtKB)

\subsection{EXPRESSÃO GÊNICA X PROTEÔMICA}

Finalmente, a comparação entre os resultados obtidos pelas duas técnicas foi realizada objetivando-se traçar um panorama geral dos eventos ocorridos na célula tanto do ponto de vista genômico quanto proteômico. Para melhorar o grau de correlação dos experimentos, foram utilizadas células e reagentes provindos de um mesmo lote.

Apesar de 53.617 transcritos terem sido detectados por microarranjo, apenas 1.536 (2,9\%) apresentavam fold change mínimo e foram identificados pelo programa DAVID Bioinformatic Resources. Já pela proteômica, 2.484 proteínas foram identificadas no total, mas apenas 714 (28,7\%) apresentavam fold change mínimo e foram identificadas pelo programa DAVID Bioinformatic Resources.

Os genes pertencentes às vias já discutidas anteriormente e que também apresentaram seus produtos (proteínas) identificados por espectrometria de massas, foram comparados. Nesse grupo de genes avaliados, apenas 16,6\% (12 de 72) foram também identificados na análise proteômica. Os resultados mostram que os valores de alguns genes/proteínas são correlacionados, enquanto outros apresentam diferenças expressivas (Figura 30).

Claramente, na maioria dos casos onde genes apresentam-se hiperexpressos nos momentos iniciais, níveis elevados da proteína também são exibidos em 24 horas. Esse é o caso das integrinas alfa 6 e 2 (ITGA6 e ITGA2) e da zyxina (ZYX), envolvidas na adesão focal, da calpaína 2 (CAPN2) que é envolvida com a 
degradação substratos e desencadeamento da apoptose, além do fator de crescimento epidérmico (EGFR), uma proteína de membrana que induz a proliferação celular envolvida tanto na via MAPK quanto na adesão focal.

A mesma correlação foi encontrada também em se tratando de genes hipoexpressos. Os níveis de proteínas relativos a esses genes também estavam hiporeguladas, como a proteína quinase quinase 6 ativada por mitógeno (MAP2K6). Os resultados indicam que, mesmo que os níveis de expressão gênica retornem aos níveis basais, ou até mesmo sejam hiperexpressos posteriormente, a quantidade de proteínas encontradas após 24 horas ainda se correlaciona com a expressão gênica inicial. Este foi o caso da fosfatase de dupla especificidade 9 (DUSP9), e da proteína de choque térmico 1A (HSPA1A), ambas envolvidas na via MAPK.

Por fim, alguns genes não exibiram uma boa correlação com a quantidade de proteínas identificadas, apresentando hiperexpressão gênica e hipoexpressão de proteínas. São eles a vinculina (VCL), actina beta (ACTB), integrina alpha V (ITGAV) e a proteína de resistência antiestrogênica do câncer de mama (BCAR1), sendo que todos participam da adesão focal.

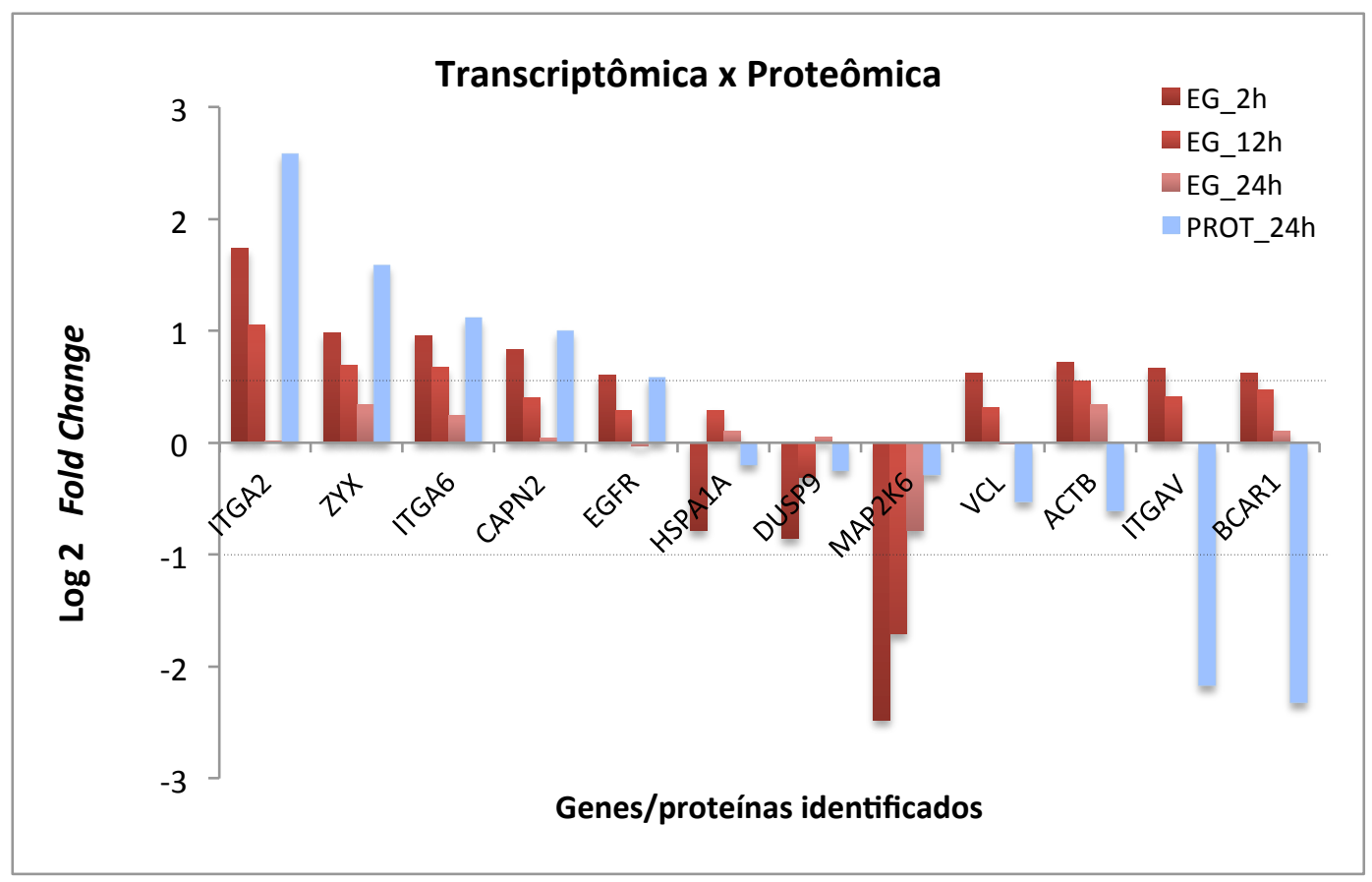

Figura 30| Comparação das alterações de expressão gênica versus síntese proteica em células HeLa tratadas com a BmPLA2. Aqui, encontram-se os genes (em vermelho) pertencentes às vias biológicas previamente discutidas os quais tiveram suas respectivas proteínas (em azul) detectadas no ensaio proteômico. Os dados apresentados são o $\log _{2}$ da 
alteração na expressão em relação ao controle (fold change). As linhas pontilhadas sinalizam os limites considerados significativos para ambos os ensaios $(\geq 1,5$ ou $\leq 0,5$ fold change).

A lista completa com os resultados da expressão gênica, bem como da proteômica por serem muito grandes não puderam ser anexadas neste trabalho devido ao seu tamanho. Todavia, estamos avaliando a possibilidade de submetê-las a um banco de dados apropriado, disponibilizando-as à toda comunidade científica e assim, incentivando outros pesquisadores de diferentes áreas a apreciá-las a partir da perspectiva de suas próprias áreas de perícia, uma vez que muitos outros resultados e conclusões podem ainda ser extraídos deste trabalho. 
5. DISCUSSÃO 


\section{DISCUSSÃO}

PRIMEIRA ETAPA: AVALIAÇÃO DA ATIVIDADE CITOTÓXICA DA PEÇONHA DE B. marmoratus

O câncer é uma doença que vem aumentando suas taxas de incidência e mortalidade em todo o mundo. Atualmente, há uma busca constante por novos tratamentos e compostos anticâncer eficientes e não indutores de efeitos colaterais severos. Nesse sentido, diversas moléculas isoladas da peçonha de serpentes vêm sendo avaliadas, uma vez que possuem uma vasta gama de componentes que podem interferir em processos celulares fundamentais ao desenvolvimento de processos tumorais (de Carvalho et al., 2001; Gebrim et al, 2009; Rodrigues et al, 2009).

No presente trabalho, foram avaliados os efeitos citotóxicos da peçonha bruta da serpente do cerrado Bothrops marmoratus, bem como de uma PLA2-Lys49 isolada dessa peçonha sobre células cancerígenas.

As linhagens escolhidas para realização dos ensaios de citotoxicidade com a peçonha bruta foram HeLa (câncer do colo do útero humano), B16F10 (melanoma murino), MCF-7 (câncer de mama) e uma linhagem normal NIH/3T3 (fibroblasto murino) obtidas do banco de células ATCC. Essas linhagens são muito utilizadas como modelos experimentais em diversos estudos em todo o mundo e possuem algumas características marcantes como a capacidade de crescer aderidas ao substrato, não apresentarem caspase-3 (Janicke 1998) e responderem diferentemente à presença de estrógeno ( Somasekhar \& Gorski, 1988; Levenson \& Jordan, 1997).

Os resultados obtidos nessa avaliação mostraram a capacidade da peçonha bruta de inviabilizar as células testadas de maneira dose-dependente com 24 horas de incubação. A citotoxicidade foi verificada nas três linhagens testadas, todavia, com sensibilidades levemente diferentes dependendo da linhagem, o que sugere um mecanismo de ação ou afinidade diferentes em relação a cada uma das linhagens celulares.

Diversos estudos demonstram a atividade citotóxica da peçonha bruta de serpentes sobre diferentes tipos celulares. Um estudo do efeito da peçonha de B. jararacussu avaliou sua ação citotóxica sobre o crescimento de uma linhagem 
celular de tumor ascítico de Ehrlich (EAT) e sobre células peritoneais in vivo e in vitro (da Silva et al., 2002). Essa peçonha apresentou toxicidade em todas as concentrações testadas de maneira dose-dependente. 0 estudo comparativo in vitro evidenciou que a taxa de viabilidade celular das células peritoneais foi significativamente maior que a de células tumorais incubadas com 2,5; 5 e $10 \mathrm{mg}$ da peçonha por $3 \mathrm{~h}$. Porém, com $24 \mathrm{~h}$ de incubação foi observado um efeito inverso, onde a viabilidade das células tumorais foi maior do que a de células peritoneais em todas as concentrações.

$0 \mathrm{IC}_{50}$ relativo da peçonha de $B$. marmoratus apresentou valores de IC50 diferentes dependendo da linhagem celular avaliada. As peçonhas de B. alternatus e B. diporus também demonstraram atividade citotóxica sobre uma linhagem celular de mioblastos, sendo que a peçonha de $B$. diporus foi expressivamente mais tóxica ( $\mathrm{IC}_{50}=2 \mu \mathrm{g} / \mathrm{mL}$ ) do que a de B. alternatus ( $\mathrm{IC}_{50}=5,8 \mu \mathrm{g} / \mathrm{mL}$ ) (Bustillo, Lucero \& Leiva, 2009).

Outro trabalho realizado utilizando uma linhagem de células Vero (células epiteliais de rim extraídas de um macaco africano) mostrou a citotoxicidade da peçonha de B. neuwieddi mattogrossensis $\left(\mathrm{IC}_{50}=4,74 \mu \mathrm{g} / \mathrm{mL}\right), \quad$ B. leucurus $\left(\mathrm{IC}_{50}=4,95 \mu \mathrm{g} / \mathrm{mL}\right)$ e B. atrox $\left(\mathrm{IC}_{50}=34,64 \mu \mathrm{g} / \mathrm{mL}\right.$ ) (Oliveira et al., 2002).

Esses resultados mostram que existe variação entre a toxicidade das peçonhas entre si e que também depende da linhagem celular utilizada. Em geral, as peçonhas da família Viperidae atuam diretamente sobre as células tumorais e sua atividade pode ser direta ou devida ao fenômeno indireto da resposta inflamatória mediada por IL2, IL8 e TNF- $\alpha$ (Silva, Fecchio \& Barraviera, 1996).

A redução da viabilidade celular analisada pela metabolização de MTT indica três possíveis hipóteses: ao longo do período de incubação, as frações testadas podem induzir (1) a redução da proliferação celular, (2) a morte celular ou (3) ambos simultaneamente. Além disso, a morte celular pode ocorrer por diferentes mecanismos como a indução de apoptose, aumento do influxo de cálcio, indução da liberação de citocromo $C$, diminuição ou aumento da expressão de proteínas que controlam o ciclo celular ou ainda devido a danos na membrana celular (Papo \& Shai, 2005; Vyas et al., 2013). Daí a necessidade de prosseguir com outros ensaios a fim de determinar qual desses mecanismos estão envolvidos na redução da viabilidade celular causada pela peçonha de B. marmoratus. 
Apesar de efeito necrótico desses venenos induzir o pensamento de que o mecanismo de ação da peçonhas botrópicas seria a indução de necrose devido a ação conjunta do coquetel enzimático encontrado nessa peçonha, o resultados obtido por citometria de fluxo utilizando anexina $\mathrm{V}$ e Iodeto de propídeo demonstram claramente que a peçonha bruta de B. marmoratus induz morte celular principalmente pela via apoptótica.

A degradação do DNA, em unidades chamadas nucleossomos, que também é uma das características marcantes da morte celular por apoptose e ocorre de maneira dependente de caspases (Wang et al., 2005), pode ser usada para corroborar esse indício de morte celular por apoptose. A análise da fragmentação de DNA obtida por citometria de fluxo mostrou que a porcentagem média de DNA fragmentado aumentou aproximadamente 4,5 vezes nas células tratadas em relação ao controle $(18,3 \%$ versus $4,1 \%)$, valor estatisticamente significativo e que juntamente com o resultado obtido com o uso de anexina, sugere a ocorrência de apoptose nessas células, ou seja, a morte celular programada de maneira dependente de caspases. Estudos têm mostrado cada vez mais que diferentes peçonhas e seus componentes individualmente como L-aminoácido oxidases, lectinas, disintegrinas e PLA2s podem induzir apoptose (Alves et al., 2008; Bustillo et al., 2009; Nunes et al., 2012; Tanjoni et al., 2005), provendo assim novas informações sobre os mecanismos de citotoxicidade dos venenos botrópicos.

A análise do ciclo celular demonstrou que o tratamento das células HeLa com a peçonha de B. marmoratus resultou na parada do crescimento, caracterizado por uma acumulação na fase $S$ do ciclo celular que saltou de 11,6\% (controle não tratado) para 13,5\%, com uma concomitante diminuição da percentagem de células na fase G2 / M. As células que estão se replicando normalmente passam de fase G1 do ciclo para a fase $S$, onde ocorre a síntese de DNA. A fase $S$ é seguida pela fase G2, onde as células se preparam para a duplicação na fase M (Foster 2008). Todavia, um estresse genotóxico pode transitoriamente atrasar a progressão do ciclo celular em G1, S ou G2, ou mesmo impor pausas ou prisões prolongadas do ciclo celular.

Os pontos de checagem da fase intra $S$ podem ser ativados por injúrias genotóxicas causando, em grande parte, uma inibição transitória e reversível da replicação de DNA (Molinari 2000; Kastan \& Bartek 2004). Os mecanismos envolvidos permanecem um tanto obscuros, mas sabe-se que atuam principalmente 
de duas formas. A primeira envolve o complexo mitótico ciclinaB-cdc2 ou Fator Promotor da Mitose (MPF) que normalmente permanece inativo durante toda a fase S e protege a célula de uma divisão antes que ela esteja totalmente pronta para isto. A segunda está relacionada com o complexo ciclina A-cdk2. Imediatamente antes da síntese de DNA, esse complexo fosforila proteínas específicas envolvidas nas origens de replicação do DNA. Estas proteínas, conhecidas como fatores licenciadores, ligamse a determinados pontos da molécula de DNA, reduzindo o grau de tensão da duplafita, a fim de que seja replicada. Os fatores licenciadores acumulam-se durante G1, atuam em S, e são destruídos em G2 para impedir nova replicação antes da mitose. Os pontos de metilação são igualmente importantes nesta fase e sinalizam que determinada sequência já foi replicada, impedindo excesso de material duplicado.

Sabe-se também que a parada na fase $S$ ocorre devido à perda da atividade de Cdk2 e a formação reduzida de complexos ativos de ciclina E/Cdk2 quinase (Laezza et al., 2006; Lin et al., 2006). Apesar de não ser observada com frequência, alguns estudos mostraram que essa parada na fase $S$ pode ser ocasionada pelo tratamento de uma linhagem celular HepG2 com alguns agentes quimioterapêuticos ( Murphy et al., 2001; Ji et al., 2008). Além disso, a Cytotoxin III (CTX III), uma toxina polipeptídica isolada da peçonha de Naja naja atra também pode inibir a proliferação e promover a apoptose de células de câncer sólido HepG2 induzindo a parada do ciclo celular na fase S (Chen et al., 2009).

A combinação desses resultados fornece portanto indícios de que a ação da peçonha bruta sobre as células ocorre sobretudo induzindo a parada do ciclo celular na fase $S$, seguido de indução de apoptose.

SEGUNDA ETAPA: PURIFICAÇÃO DA BmPLA2 E SUA AÇÃO EM CÉLULAS HELA

As peçonhas de serpentes são uma mistura complexa de componentes com diversas propriedades químicas e físicas, as quais são responsáveis pelos múltiplos efeitos biológicos apresentados durante o envenenamento. É muito importante conhecer sua ação enquanto mistura, uma vez que diversos componentes podem apresentar efeitos complementares ou até mesmo sinérgicos (Matsui, Fujimura \& Titani, 2000; Mora-Obando et al., 2014). Todavia, muitos estudos têm levado ao isolamento de proteínas e peptídeos e uma melhor caracterização de suas atividades enzimáticas e biológicas de maneira individual. 
Esses estudos utilizando toxinas isoladas, além de permitirem uma compreensão mais aprofundada sobre o envenenamento, conduzem à identificação de novas moléculas com potenciais aplicações biotecnológicas.

Ao determinar a metodologia de fracionamento de peçonhas para estudos relacionados com a estrutura e função de proteínas, a qualidade da preparação das amostras é um dos parâmetros fundamentais, uma vez que contaminantes podem interferir significativamente, dificultando a obtenção e interpretação dos resultados. Além disso, a eficiência, capacidade, resolução, recuperação, custo e rapidez também devem ser levados em consideração, uma vez que podem fazer muita diferença a curto, médio ou longo prazo. Daí a importância de escolher bem o método de purificação e considerar todos esses aspectos antes de determinar a metodologia que será adotada durante todo o restante do trabalho.

Toxinas isoladas das peçonhas de serpentes, incluindo as botrópicas, têm sido purificadas utilizando complexas combinações de métodos cromatográficos, tais como: cromatografias de afinidade (utilizando inibidores naturais como anticorpos ou heparina), exclusão molecular, troca iônica e fase reversa ( Soares et al., 2000; Mora et al., 2005; Zouari-Kessentini et al., 2009; Patiño et al., 2010; Khunsap et al., 2011). Nota-se que os métodos mais utilizados inicialmente eram os envolvendo principalmente exclusão molecular e troca iônica, devido à disponibilidade de equipamentos, reagentes e por possuírem uma maior capacidade considerando-se a quantidade de amostra injetada. Todavia, as cromatografias de fase reversa vêm se popularizando e diversos grupos de pesquisa já adotaram essa metodologia devido à rapidez e eficiência da separação.

0 fracionamento da peçonha bruta de B. marmoratus foi realizado por diversas metodologias a fim de se determinar as melhores condições para separação de seus componentes. A cromatografia por troca iônica foi a que apresentou o pior resultado no quesito resolução. A cromatografia de exclusão molecular apresentou um perfil de separação melhor, todavia ainda era necessário uma segunda etapa cromatográfica. A combinação de uma cromatografia por exclusão molecular seguida por uma etapa de fase reversa pareceu eficiente, uma vez que atingia o grau de pureza necessário, mantendo a atividade da PLA2. Entretanto, esse tipo de abordagem mostrou-se pouco reprodutível. Cada novo lote de reagentes era preparado rigorosamente quanto à pesagem, medição e ajuste do pH, manutenção 
da temperatura e pressão, fatores que podem interferir nessas metodologias. Mesmo assim, o perfil de separação sofria alterações consideráveis, dificultando assim a identificação da fração de interesse.

A cromatografia de fase reversa em coluna $\mathrm{C}_{18}$ possibilita uma separação de maneira muito rápida, quando comparada com outras metodologias. Todavia, alguns contaminantes compostos principalmente por isoformas ainda eluíam junto com a PLA de interesse. Um ajuste simples no método padrão possibilitou a separação da BmPLA2 em apenas uma etapa. Tal ajuste consistiu em estender o gradiente de separação, aumentando a concentração de acetonitrila de maneira mais gradativa antes e durante a eluição da BmPLA2. Dessa maneira, foi possível purificar de maneira eficiente a BmPLA2 em apenas uma etapa (Figura 14).

A determinação seu do grau de homogeneidade e da massa molecular realizada por espectrometria de massas do tipo MALDI-TOF/TOF mostrou que além do íon correspondente à BmPLA2 $\left([\mathrm{M}+\mathrm{H}]^{+}=13.728,6\right)$, também foi detectado um outro com $[\mathrm{M}+\mathrm{H}]^{+}=13.933,6$ que corresponde a um íon aduto, formado pela BmPLA2 ligada a uma molécula de matriz.

O uso de matrizes derivadas de ácido cinâmico, particularmente o ácido sinapínico (SA), permitem a análise de proteínas pela geração de um íon molecular protonado que pode ser detectado em espectrômetro de massas do tipo MALDI-TOF. Todavia, é comum encontrar nesses espectrogramas adutos de matriz, que podem gerar confusão durante a análise dos dados obtidos (Beavis \& Chait 1990; Fung 2005).

Os íons de aduto encontrados quando se utiliza a matriz de SA são 205-206 Da maior do que a da massa da proteína protonada e corresponde à adição de uma molécula de matriz com uma perda concomitante de água $\left(\left[\mathrm{M}+\left(\mathrm{SA}-\mathrm{H}_{2} \mathrm{O}\right)+\mathrm{H}\right]^{+}\right)$ (Fung 2005) e são geralmente desconsiderados das análises (Creer et al. 2003).

A abundância relativa dos íons de aduto de matriz dependente não só do equipamento utilizado e da preparação do analito e da matriz, mas do tamanho da proteína analisada. Provavelmente, as moléculas da matriz se ligam preferencialmente aos chamados "mini-epítopos" do íon, que podem consistir de um ou poucos aminoácidos. Naturalmente, proteínas maiores têm uma maior probabilidade de possuir esses "mini-epítopos" (de Boer et al., 2009). 
A atividade citotóxica da BmPLA2 foi testada em células HeLa e foi possível observar que mesmo em concentrações muito baixas (entre 0,57 e 1,1 $\mu \mathrm{M}$ ) já foi possível observar sua atividade citotóxica. 0 IC $_{50}$ relativo determinado foi de $8,7 \pm$ $0,9 \mu \mathrm{M}$, ou $120,6 \mu \mathrm{g} / \mathrm{mL}$

O IC50 encontrado para outras PLA2s isoladas de serpentes do mesmo grupo como as três PLA2s isoladas de B. neuwiedi que demonstraram atividade citotóxica in vitro contra células de melanoma (B16F10) também avaliadas pelo método do MTT foi de $31 \mu \mathrm{g} / \mathrm{mL}$ para uma isoforma pertencente à classe P-3, e de $15 \mu \mathrm{g} / \mathrm{mL}$ para as outras duas isoformas pertencentes às classes P-1 e P-2 (Daniele et al., 1997).

0 valor do IC $_{50}$ encontrado para BmPLA2 é superior, todavia, cabe lembrar que a dose letal pode variar significantemente dependendo da linhagem tumoral testada. Assim como os ensaios utilizando a peçonha bruta variaram, essa diferença também pode ocorrer com a toxina isolada. Ao contrário da BmPLA2, essas PLA2s citadas, apresentam atividade fosfolipásica, o que poderia implicar em diferentes mecanismos de ação. Estudos prévios realizados durante o mestrado (Macêdo 2011) mostraram que a BmPLA2 não possui atividade catalítica ou fosfolipásica, possui fraca atividade hemolítica e trata-se de uma PLA2 do tipo Lys49, apresentando similaridade com outras duas PLA2s Lys 49 isoladas da peçonha de B. moojeni (Azevedo Jr et al. 1997) e de B. neuwiedi pauloensis (Soares et al., 2000).

As PLA2s Lys49, também chamadas de PLA2-símile, possuem baixa ou nenhuma atividade enzimática sobre substratos artificiais e são amplamente estudadas. Apesar de não serem capazes de hidrolisar fosfolipídeos, apresentam outras atividades biológicas e por isso têm atraído a atenção como modelos de indução de citotoxicidade e mionecrose por um mecanismo de ação cataliticamente independente (Polgár et al., 1996; Delatorre et al., 2010).

Um exemplo de fosfolipase A2 Lys-49, ou seja, desprovida de atividade enzimática e que apresentou redução da viabilidade de células tumorais é a miotoxina-II ou MjTX-II de Bothrops moojeni. Ela foi testada contra as linhagens celulares de câncer de mama (SK-BR-3), leucemia aguda de células T (JURKAT) e tumor ascítico de Ehrlich (EAT) e na maior concentração testada $(1 \mathrm{mg} / \mathrm{mL})$ inibiu em torno de 30 a 85\% das células dependendo da linhagem (Stábeli et al. 2006). 


\section{Transcriptômica e proteômica de células HeLa tratadas com a BmPLA2}

Moléculas de interesse para a indústria farmacêutica, por exemplo, devem ser além de potentes, específicas sobre determinado alvo ou via biológica, apresentando efeitos mínimos sobre outros alvos. A validação de drogas envolve a confirmação de que a interação da droga é específica, bem como o desenvolvimento de estudos acerca de seus efeitos secundários (Debouck \& Goodfellow 1999).

Métodos globais como estudos genômicos e proteômicos, que podem investigar a alteração simultânea de diversos genes ou proteínas de maneira quantitativa, permitem uma visão abrangente sobre como um composto interfere sobre o metabolismo celular e podem acelerar a identificação das atividades ou efeitos secundários ou indesejados (Russell, Rahman \& Mohammed, 2013).

No entanto, está se tornando cada vez mais claro que abordagens "ômicas" realizadas individualmente podem não ser suficientes para caracterizar a complexidade de um sistema biológico. 0 nível de expressão de um dado gene, nem sempre apresenta uma boa correlação com a quantidade de proteína produzida, sua localização ou atividade biológica. Além disso, diversos níveis de regulação podem ocorrer após a transcrição, como a regulação pós-transcricional, traducional e póstraducional, além de outras formas de controle e processamento bioquímico. Considerando isso, abordagens integradas têm sido aplicadas e estão possibilitado a caracterização de novos mecanismos reguladores e redes metabólicas complexas (Hegde, White \& Debouck, 2003; Mootha et al., 2003; Wilmes et al., 2013).

Aqui, cabe uma reflexão sobre o significado de genes e proteínas regulados ou sintetizadas para mais ou para menos. Ao comparar células tratadas com algum agente estressor com células não tratadas, temos um percentual de genes/proteínas positivamente regulados, outros negativamente, e ainda uma grande parcela que não é alterada. A questão é, analisando-se do ponto de vista biológico, independentemente do papel individual de cada gene/proteína regulado, uma alteração na expressão sugere um ajuste fisiológico específico que o organismo está acionando em resposta ao estressor. Todavia, é difícil dar um significado mais profundo sobre determinados genes/proteínas, bem como sobre determinada via, especialmente quando existem genes/proteínas diferentemente reguladas dentro de uma mesma via. 
Uma quantidade razoável sobre vias que podem ser ativadas em resposta ao estresse são conhecidas, mas ainda há muitas informações desconhecidas. Em análises desse tipo, não é surpreendente obter uma regulação positiva maciça (tanto em número de produtos de genes e intensidade) e a intensidade de uma regulação positiva de genes pode ser proporcional à potência do estressor, mas não leva necessariamente à presença proporcional da proteína. Por isso, a interpretação dos dados deve ser feita com muita cautela, especialmente quando comparamos intensidades de expressão gênica e proteica.

A análise transcriptômica de células HeLa tratadas com a BmPLA2 na concentração equivalente ao $\mathrm{IC}_{50}$ permitiu a identificação de 53.617 transcritos, sendo 1.549, 700 e 526 genes em 2, 12 e 24 horas respectivamente, com o fold change preconizado, e um total de 1.964 genes identificados pelo programa DAVID Bioinformatic Resources. Já na análise proteômica, 4.459 proteínas foram identificadas, sendo 857 com o fold change estabelecido e 714 proteínas identificadas pelo DAVID e utilizadas portanto para as análises de Gene Ontology e vias biológicas alteradas.

Os resultados da expressão gênica mostraram que as alterações ocorridas com $2 \mathrm{~h}$ de tratamento são muito maiores do que as que ocorrem após 12 ou 24 horas. Além disso, na maioria dos casos essas alterações não são duradouras.

O perfil de expressão gênica gerado de acordo com o tempo de tratamento das células com a BmPLA2 levou à construção de padrões que puderam ser comparados entre si e por meio dessa análise, apresentada na figura 17, o grupo de células tratadas por 24 horas apresentam-se mais próximas ou com um perfil mais semelhante ao grupo controle do que as células tratadas por 2 ou 12 horas.

Alterações nos níveis de expressão gênica ao longo do tempo em resposta à perturbações teciduais ou celulares têm sido estudadas em diferentes modelos celulares e técnicas. Sabe-se que as respostas geradas podem variar de acordo com o estímulo, o tecido ou célula estudado, ou até mesmo da via biológica observada. Enquanto alguns estudos apontam genes com um pico de alteração em torno de 1 hora, outros podem levar até 48 horas (Polyak et al., 1997; Louis et al., 2007; Agudo et al., 2008).

Perturbações no meio podem ser detectadas rapidamente e gerar uma resposta imediata, levando a alterações no perfil de expressão. Essas alterações 
podem ser coordenadas tanto em quantidade quanto em duração. Geralmente, quando há mudanças drásticas no meio, certos genes podem aumentar ou diminuir seus níveis drasticamente, porém de maneira temporária. Em seguida, esses mesmos genes sofrem outra regulação e atingem um outro estado, que é frequentemente diferente do estado inicial de "descanso" (Ramoni, Sebastiani \& Kohane, 2002; Chechik \& Koller, 2009). Deve-se considerar também que existe uma forte relação entre a função do gene e o momento em que este será regulado. Como consequência, nem todos os genes terão seus níveis de expressão alterados ao mesmo tempo, o que implica uma necessidade de considerar isso nas análises e avaliar não só os valores quantitativos, mas tendências em grupos de genes (Chechik \& Koller 2009).

A proteômica, por sua vez, permite o estudo da estrutura e função das proteínas em determinada amostra biológica e em larga escala. Para isso, diversas ferramentas disponíveis atualmente permitem análises de alto rendimento para a detecção, identificação e investigação funcional de um proteoma.

0 processamento e análise dos dados obtidos por proteômica é um processo de várias etapas e bastante complexo (Listgarten \& Emili 2005; Kearney \& Thibault 2003) sendo esta a principal dificuldade para a realização de estudos maiores. Para superar esses problemas, a preparação eficaz da amostra, redução da sua complexidade, enriquecimento de componentes menos abundantes e redução dos componentes mais abundantes tornam-se extremamente necessários (Chandramouli \& Qian, 2009). Dessa forma, uma ampla variedade de abordagens estão disponíveis e incluem sobretudo: aplicações baseadas em gel, tais como electroforese unidimensional e bidimensional em gel de poliacrilamida (Van den Bergh \& Arckens, 2005; Vercauteren et al., 2004), ou metodologias livres de gel que incluem a tecnologia de identificação multidimensional de proteínas (Florens \& Washburn 2006), etiqueta de afinidade codificada com isótopos (ICAT) (Gygi et al., 1999); SILAC (Ong et al., 2002); marcação isobárica para quantificação absoluta e relativa (iTRAQ) (Ross et al. 2004). Proteômica do tipo "shotgun" (Wolters et al., 2001) e 2DE DIGE (Klose et al., 2002), bem como microarranjos de proteínas (Cutler, 2003) são aplicados para se obter visões gerais de expressão da proteína em tecidos, células e organelas. Ensaios de Western blot em grande escala (Schulz et al., 2007), monitoramento de reações múltiplas (MRM) (Stahl-Zeng et al., 2007), e 
quantificação de alta resolução sem marcação de dados de LC-MS (Mueller et al., 2007) estão sendo utilizados para análise de alto rendimento.

Nesse estudo, a metodologia utilizada apesar de não oferecer a quantificação absoluta das amostras, permite a identificação de uma vasta quantidade de proteínas de forma rápida e menos complexa do que as técnicas que envolvem quantificação. No entanto, é preciso confirmar a participação desses resultados por outras técnicas de validação utilizando alguma tecnologia independente, como por exemplo as baseadas em anticorpos (western ou northern blots e ELISA).

Diversas proteínas também foram detectadas através da análise proteômica. Considerando o diagrama de dispersão (figura 28), nota-se que existe uma boa correlação entre as proteínas encontradas em células tratadas e não tratadas, especialmente as com maior abundância. As proteínas pouco abundantes por sua vez, apresentam baixa correlação, ou seja, são consideradas diferencialmente expressas pelos métodos estatísticos aplicados e, portanto, alvo de nossos estudos.

Proteínas pouco abundantes são muitas vezes ignoradas, porque as tecnologias e métodos atualmente disponíveis não são suficientes para detectá-las e, muitas vezes, as análises estatísticas podem subestimá-las. No entanto, biologicamente, o fato de uma proteína ser limitada a certos períodos e processos ou estar em baixas quantidades em uma célula, não significa que não possa ser de extrema importância. Pelo contrário, muitas delas podem ser essenciais para a manutenção da integridade celular e participarem de processos essenciais ao bom funcionamento celular (Pedersen et al., 2003; Boschetti \& Righetti, 2013).

Embora haja uma grande quantidade de genes/proteínas nas células tratadas por 24 horas com valores semelhantes às células não tratadas, sugerindo alguma correlação entre a transcriptômica e proteômica, a ocorrência de proteínas identificadas em ambos ensaios foi baixa e os valores quantitativos, relativamente diferentes.

Apesar da ideia de que a correlação entre os níveis de expressão de mRNA e proteína deva ser alta, estudos disponíveis ainda falham em encontrar tais resultados experimentalmente. Já foi demonstrado até agora, em quase todos os organismos estudados, que a abundância de transcritos pode prever apenas parcialmente abundância de proteínas (de Sousa Abreu et al., 2009) e grande parte 
dos trabalhos mostram baixa ou, em alguns casos, nenhuma correlação (Gygi et al., 1999; Wilmes et al., 2013). Sugere-se que essa discrepância ocorra devido a fatores biológicos como os processos regulatórios pelos quais as proteínas são submetidas após sua síntese ou diferenças entre a meia vida de proteínas e mRNA, mas também possivelmente devido à características experimentais como o preparo das amostras e parâmetros usados para as análises (Nie et al., 2007; Nagaraj et al., 2011).

Os dados obtidos por microarranjo e proteômica quando analisados conjuntamente, a princípio, sugerem que exista baixa correlação. Essa baixa correlação em um nível global não necessariamente exclui a possibilidade de que alguns pares de mRNA/proteína tenham alta correlação. Além disso, é muito importante identificar os padrões de correlação em grupos de genes/proteínas que participam de uma mesma via, mesmo que eles não sigam tendências gerais. Só assim, podemos alcançar uma melhor compreensão da relação mRNA/proteína nas células dentro do evento biológico em estudo.

Algumas vias que tiveram genes/proteínas alterados e relacionados a processos biológicos de interesse foram estudadas de maneira mais detalhada e serão discutidas a seguir.

\section{Via MAPK}

A via MAPK é um mediador importante em eucariotos de respostas transcricionais a sinais extracelulares, sendo conhecida por resultar na indução imediata de genes (Whitmarsh, 2007). Como já foi mencionado, essa via pode ser dividida em grupos de genes que são ativados dependendo de estímulos específicos. 0 tratamento de células HeLa com a BmPLA2 com uma dose equivalente ao $\mathrm{IC}_{50}$ claramente alterou a expressão de genes relacionados a 3 desses grupos, também chamados de vias, sendo elas ERK, JNK p38.

ERK é uma via associada a crescimento, proliferação e sobrevida celular, que protege as células da apoptose e embora ainda haja muito a ser esclarecido, já está claro que a via de sinalização ERK é controlada por mecanismos de regulação altamente dinâmicos e complexos. Em sua maioria, a ativação é mediada pelo receptor da pequena proteína $G$, Ras. No entanto, ela também pode ser iniciada em outros compartimentos intracelulares, além da membrana plasmática, e sabe-se que numerosos fatores auxiliares, tais como as proteínas arcabouço ERK (ERK scaffolding) e moduladoras da sinalização, desempenham papéis importantes na 
determinação da força, duração e localização da sinalização de ERK (McKay \& Morrison, 2007; Junttila et al., 2008).

$\mathrm{O}$ equilíbrio da via JNK (quinase c-Jun $\mathrm{N}$-terminal) é necessário para a homeostase celular e, quando a célula recebe fortes estímulos de estresse, estes são transformados, levando frequentemente à apoptose. Além do stress celular , essa via pode ser ativada por citocinas e assim ativar apoptose ou até mesmo proliferação e sobrevivência, dependendo das condições e estímulos celulares (Weston \& Davis 2007). JNK pode ativar diversos fatores de transcrição como o ATF-2, Elk-1, MEF-2c, p53 e c-Myc, além de outros substratos como as proteínas anti-apoptóticas, Bcl-2 e Bcl-xL. Todavia, o substrato mais clássico é o fator de transcrição c-Jun, que inclusive dá nome a esta via (Yamamoto, Ichijo \& Korsmeyer, 1999; Shaulian \& Karin, 2002).

Já a via MAPK p38 pode ser ativada por uma grande quantidade de citocinas inflamatórias, agentes patogênicos além de estresse ambiental como estresse osmótico, luz ultravioleta, choque térmico e hipóxia (Ashwell 2006). Sua ativação é necessária para a indução de apoptose em vários modelos celulares diferentes (Tanaka et al., 2002; Kinase et al., 2003), mas também já foi relatada como uma via que atua a favor do crescimento de células tumorais quando comparados com os controles correspondentes (Junttila et al., 2007).

Como é possível notar, diversos genes apresentaram-se hiperexpressos enquanto alguns estão hipoexpressos, independente de sua função (podendo estar envolvidos positiva ou negativamente com a indução de apoptose, por exemplo). Conjuntamente, os dados mostram que esta via está passando por diversas regulações em diferentes níveis e tempos a fim de gerar uma resposta. Não foi possível concluir com certeza os resultados biológicos gerados a partir de tais alterações devido aos efeitos múltiplos gerados por esta via. No entanto, como ela possui subdivisões ou grupos de genes que respondem a estímulos de maneira diferenciada e específica, podemos concluir que a BmPLA2 é percebida pela célula como diferentes estímulos, ativando assim as vias ERK, JNK e p38.

Em muitos cânceres, alterações na via MAPK levam ao crescimento descontrolado de células. Além disso, a ativação de algumas vias, incluindo ERK por células endoteliais atuam aumentando a migração e inibindo anoikis em células tumorais (Neiva et al. 2009). Sendo assim, compostos capazes de inibir ou controlar essa via podem ser potencialmente úteis no desenvolvimento de novos fármacos 
(Wong 2009). 0 tratamento com a BmPLA2 foi capaz de inibir alguns genes nas horas iniciais, enquanto outros foram superexpressos inicialmente, seguidos por hipoexpressão. Não se sabe o efeito a longo prazo desse tratamento, mas seria muito útil avaliar o efeito desta ou outras PLA2s sobre essa via em um estudo mais prolongado a fim de estimar seus efeitos também a longo prazo.

\section{Adesão focal}

A interação física entre células e a matriz extracelular permite sua comunicação com o meio externo, identificação de estímulos e consequente produção de respostas apropriadas por meio de uma alteração no padrão de expressão gênica, e podem levar à adesão, migração, proliferação, diferenciação ou morte celular (Lo 2006).

A falta de adesão ou uma adesão inapropriada de células à matriz extracelular pode levar à morte celular programada conhecida como anoikis, descrita inicialmente por Frisch \& Francis (1994). É importante destacar que esse termo é usado para distinguir um cenário de apoptose, não um mecanismo específico, uma vez que muitos dos mecanismos apoptóticos que ocorrem em resposta a outros estresses celulares se aplicam também a anoikis ( Frisch et al., 2013).

A hiperexpressão de proteínas que participam da adesão focal está frequentemente relacionada com a resistência à anoikis, metástase de tumores e o aumento da resistência à drogas (Fine et al., 2001; Kominsky, 2006; Lee \& Luk, 2010). A hiperexpressão de Talin1, por exemplo, aumentou a adesão, migração e invasão de células de câncer de próstata, ativando sinais de sobrevida e conferindo resistência à anoikis (Sakamoto et al., 2010) 0 gene relacionado ao VEGF, encontrado hiperexpresso em nosso trabalho, liga-se aos seus receptores em células endoteliais e induz a expressão de Bcl-2. Bcl-2 aumenta a síntese e secreção de IL-6, CXCL8 e EGF por células endoteliais, que por sua vez, induzem a ativação das vias de sinalização STAT3, Akt, ERK em células tumorais (Kaneko et al., 2007). 0 resultado biológico dessa cascata é um aumento significativo na sobrevivência de células tumorais e da migração (Neiva et al., 2009).

Assim, os resultados obtidos mostram que, de maneira geral, grande parte dos genes relacionados à adesão focal em células tratadas com a BmPLA2 foram 
hiperexpressos 2 horas após o tratamento, seguidos por redução após 12 e 24 horas, o que sugere uma indução de resistência a esse tipo de morte celular.

A análise proteômica das células após 24 horas de tratamento por sua vez, mostra diversas proteínas relacionadas à adesão focal hiporeguladas, enquanto apenas algumas apresentam-se hipereguladas. Diferentes integrinas (alfa 1, alfa 5, alfa 6), proteínas ligantes de cálcio S100 (A6 e A7) ou a proteína de junção apertada 2 e pinina, associada aos desmossomos, todas importantes para a adesão de células à matriz extracelular ou adesão intercelular, encontram-se hipoexpressas.

A hipótese explicativa para tais eventos, seria que a BmPLA2 atua como um agente estressante sobre as células causando nas horas iniciais uma ativação da via MAPK, seguida por ativação de genes relacionados à adesão focal que atuariam auxiliando na resistência à anoikis e migração. No entanto, esses eventos não parecem muito evidentes após 12 ou 24 horas, uma vez que tanto os genes quanto grande parte de seus produtos proteicos encontram-se em níveis basais ou até mesmo hipoexpressos na análise proteômica. Isso não descarta que outros eventos relacionados à morte celular já estejam em andamento, uma vez que estamos olhando apenas para genes/proteínas relacionadas à adesão focal.

\section{Autofagia}

Autofagia é um processo bem notório, o qual tem mostrado um papel paradoxal no câncer, podendo ser tanto pro-tumorigênico, prevenindo a morte celular, quanto anti-tumorigênico, inibindo o crescimento e proliferação celular e promovendo a morte celular não apoptótica (revisado por Long \& Ryan, 2012; Green \& Levine, 2014). Ela pode ser induzida por uma variedade de estímulos, incluindo estresse por falta de nutrientes e energia, padrões moleculares associados a agentes patogênicos (PAMPs), hipóxia, estresse redox, entre outros. A estimulação da autofagia por esses estímulos envolve diversos sinais que têm funções sobrepostas a outras respostas de estresse celular (Kroemer et al., 2010)

A hiperregulação de genes relacionados a autofagia tem sido relatada em nível transcricional em células sob condições de estresse para várias espécies (Kouroku et al. 2007) e está ainda presente em muitas células submetidas a fatores de estresse como drogas (Kanzawa et al., 2003; Kanzawa et al., 2004)

Cinco genes envolvidos na formação dos autofagossomos foram encontrados alterados na análise transcriptômica. 0 gene GABARAPL1, envolvido na formação 
dos vacúolos, sendo essencial em uma fase tardia da maturação do autofagossomo apresentou-se hiperrexpresso em 2 horas, e seus níveis caem exponencialmente após 12 e 24 horas. Já o gene MAP1LC3B2, que expressa a proteína LC3, envolvida na elongação da membrana do fagóforo, foi encontrado ligeiramente hiperexpresso após 2 horas de tratamento com a BmPLA2, porém, hipoexpresso após 12 e 24 horas. Os níveis de LC3 no entanto, apesar de tipicamente aumentarem após a indução de autofagia, podem depender da linhagem celular e, ocasionalmente, não apresentam boa magnitude (Yorimitsu \& Klionsky 2005).

$\mathrm{Na}$ análise proteômica, apenas 2 proteínas envolvidas com autofagia foram detectadas. VMA21 vacuolar H+-ATPase homolog foi hiperregulada, enquanto Catepsina B foi hiporegulada. VMA21 é uma chaperona de montagem essencial para a ATPase vacuolar e sua diminuição reduz a capacidade de degradação dos lisossomos e bloqueia a autofagia, resultando em proliferação de autolisossomos ineficazes, vacuolização celular e atrofia do tecido (Ramachandran et al. 2013). Catepsina B está envolvida na transição entre autofagia e apoptose. Essa proteína quando liberada do lisossomo para o citoplasma, pode levar à apoptose por diferentes formas como: atacando a mitocôndria e induzindo a permeabilização da membrana e liberação de citocromo C, induzindo a formação de ROS mitocondrial, ativando promotores da apoptose da família BCL-2 ou até mesmo diretamente clivando zimogênios de caspases e caspases (revisado por Lamparska-Przybysz et al., 2005).

Tomados juntos, os resultados da transcriptômica e proteômica, indicam a possibilidade de uma participação do processo autofágico nas células, sem contudo, estar relacionada com a apoptose, uma vez que não há hiperegulação de Catepsina B.

\section{Apoptose}

Células induzidas a sofrer apoptose passam por diferentes fases. Na iniciação, a célula recebe o estímulo e ativa a maquinaria molecular para efetivação da apoptose. Na fase efetora, a maquinaria molecular se torna completamente ativada, incluindo alterações no núcleo. Por fim, na fase de degradação, os marcadores da apoptose se mostram evidentes (Lazebnik et al., 1993; McCarthy et al., 1997). Os marcadores bioquímicos da apoptose incluem a fragmentação do DNA em fragmentos de 180-200 pares de bases e a ativação de caspases, que exerce um papel chave na morfologia apoptótica. A ativação das caspases é implicada, por 
exemplo, na externalização de fosfatidilserina, uma característica bem conhecida de células apoptóticas (revisado por Saraste \& Pulkki, 2000).

Apesar da maioria das alterações envolvidas no processo apoptótico consistirem na mudança de compartimentos intracelulares, clivagens e modificações de proteínas, o resultado do estudo transcriptômico também mostrou alterações no perfil de expressão de genes relacionados à apoptose. Devido ao papel dual de muitos genes é arriscado dizer o papel de cada um dentro do contexto biológico, mas está muito claro que essa via está alterada de diversas maneiras.

Sabe-se que a apoptose pode ser iniciada por diferentes vias. Se iniciada por receptores de morte como Fas e TNF-R1, requerem pró-caspases 8 ou 10. Se iniciada em resposta a danos no DNA, ativa a via mitocondrial que envolve a ativação de membros pró-apoptóticos da família Bcl-2 (Bax, Bid) e causa alterações na permeabilidade da membrana mitocondrial e liberação do citocromo c. Este por sua vez, juntamente com sATP, Apaf-1 e pró-caspase 9, forma o apoptossomo. A caspase 9 pode então ativar outras caspases $(2,3,6,7,8,9$, e 10), atuando como um amplificador desse processo (Fulda \& Debatin 2006).

No entanto, está claro que mais de uma via pode estar ativada ao mesmo tempo. Evidências mostram haver um cross-talk entre as vias extrínseca e intrínseca na apoptose induzida pelo ligante indutor de apoptose relacionado a TNF (TRAIL). Uma vez que a caspase-8 é ativada, ela pode clivar diretamente caspase-3 para ativar a via extrínseca ou clivar a proteína da família Bcl-2, contendo o domínio de BH3 (BID) para ativar a via intrínseca (Gross et al., 1999).

A maioria dos genes alterados neste estudo pertencem exclusivamente à via extrínseca, com exceção do gene APAF1, responsável pela transcrição do fator de ativação de protease associada à apoptose 1, componente central na formação do apoptossomo, pertencente à via intrínseca (Li et al., 1997). Esse gene encontra-se hipoexpresso em todos os tempos testados, sendo estes níveis mais acentuados no tempo de 2 horas. No entanto, a ativação de genes ligados à autofagia, danos no DNA, o controle do ciclo celular, além do outros sinais pró-apoptóticos desregulados, podem ainda ativar a via intrínseca da apoptose.

É importante ressaltar que não é possível indicar inequivocadamente a presença de apoptose usando apenas um tipo de análise por diversas razões. Inicialmente, porque diversas moléculas estão envolvidas com vias distintas e 
podem estar alteradas mesmo na ausência de morte celular. As caspases, por exemplo, não são restritas à apoptose. Similarmente, a exposição de fosfatidilserina (PS), considerada um importante marcador de células apoptóticas, não ocorre em células deficientes em autofagia que estão entrando em apoptose. Além disso, exposição de PS também pode ser uma característica inicial de células entrando em partanatos ou netosis, outros tipos de morte celular. Outra razão para se ter cuidado ao classificar células entrando em apoptose seria que alguns processos que levam à morte celular podem desenvolver-se em um nível subletal ou transitório, que não conduzirá necessariamente à morte celular. 0 ponto crítico de não retorno da via apoptótica intrínseca seria a permeabilização da membrana mitocondrial (MOMP) e liberação de fatores apoptóticos, como Bax ( revisado por Galluzzi et al., 2012).

Poucos estudos foram realizados sobre o efeito das peçonhas de serpentes e suas toxinas na expressão gênica de células, todavia os dados parecem fornecer informações importantes acerca dessas peçonhas e toxinas. Um estudo realizado com células HUVECs tratadas com peçonhas de $C$. atrox e B. jararaca resultou na regulação de 33 genes, sendo 10 genes reprimidos no caso do veneno de C. atrox e 11 reprimidos após o tratamento com a peçonha de B. jararaca. Uma categorização ontológica mostrou que a principal via alterada foi a de crescimento e manutenção de células, além da transdução de sinal. Muitos dos genes regulados positivamente são envolvidos na via apoptótica por receptores aos ligantes Fas / TNF-a (Gallagher et al., 2003).

Técnicas globais como a transcriptômica têm identificado com sucesso proteínas envolvidas na regulação da apoptose. Todavia, muitos genes que ainda não foram caracterizados, podem não ser notados, mas por estarem alterados, podem potencialmente estar envolvidos. Por isso, novas técnicas como as que buscam interações entre proteínas precisam ser aplicadas com o objetivo de identificar outras moléculas que participem dessas vias (Portt et al., 2011).

Os resultados obtidos pela análise proteômica, assim como transcriptômica, parecem corroborar outros estudos que mostram a ativação da via apoptótica induzida pelo tratamento com uma PLA2-Lys49 (Liu et al., 2009; Murakami et al., 2011). Foram identificadas uma variedade de proteínas diferencialmente expressas em células HeLa tratadas com a BmPLA2, das quais muitas pertencem à vias relacionadas à morte celular e apoptose. Proteínas consideradas importantes no 
processo apoptótico como EGFR, Catenina beta 1, Rho/Rac fator de troca de nucleotídeos guanina 2 foram encontradas alteradas, indicando assim a ativação desta via.

A avaliação proteômica de células tratadas com diferentes indutores de apoptose tem sido realizada por diferentes metodologias, mas frequentemente incluem Gel 2D e espectrometria de massas MALDI-TOF ou LC-MS e são frequentemente estudados quanto à modificações pós-tranducionais, degradações ou translocações em compartimentos intracelulares. Os resultados mostram o papel controverso de muitas proteínas identificadas, todavia apontam para a ocorrência de apoptose (Tian et al., 2009; Wang et al., 2013; Yerlikaya et al., 2015).

Estes tipos de estudos in vitro é valioso porque pode apontar candidatos interessantes para experimentos biológicos mais detalhados, além de fornecer indícios sobre o mecanismo de ação da toxina usada como opção de tratamento. Tomados juntos, os resultados de transcriptômica e proteômica relativos à apoptose, mostram que essa via está certamente ativada nas células tratadas.

\section{Mecanismo de ação da BmPLA2}

Analisando de forma conjunta todas as vias alteradas nesse estudo, podemos calcular uma "linha de ação" dessa toxina que inclui alteração da via MAPK, ativação da via apoptótica juntamente com intensificação da autofagia e adesão focal, possivelmente como mecanismos de prevenção à morte celular.

Ao contrário da indução da morte celular, a ação miotóxica de PLA2s é bem conhecida e foi revisada por Montecucco, Gutiérrez \& Lomonte (2008). Sua ação sobre músculos consiste basicamente em:

1 - Ligação das PLA2s aos receptores específicos na membrana plasmática.

2 - Perturbação direta da membrana.

3 - Perda do seu potencial de membrana permitindo a entrada de um grande influxo de $\mathrm{Ca}^{2+}$ a partir do meio extracelular.

4 - Grande aumento na concentração citosólica de $\mathrm{Ca}^{2+}$.

5 - Hipercontração de miofilamentos, que por sua vez, podem causar danos mecânicos para a membrana plasmática.

6 - Captação de $\mathrm{Ca}^{2+}$ pela mitocôndria por meio da uniporter resulta em inchaço mitocondrial, desorganização das cristas, formação de cristais de hidroxiapatita e 
densidades floculantes, e a abertura do poro de transição de permeabilidade, resultando assim em uma deficiência grave da função mitocondrial.

7 - Proteinases dependentes de $\mathrm{Ca}^{2+}$ (calpainas) são ativadas.

8 - Degradação de componentes do citoesqueleto o que afeta mais a integração mecânica da célula.

9 - PLA2 citosólicas dependentes de $\mathrm{Ca}^{2+}$ são ativadas e promovem ainda mais a hidrólise de membranas intracelulares e plasmática (MP).

10 - Ruptura da MP permite a entrada de mais PLA2s que hidrolisam e conduzem a danos intracelulares nos sistemas de membranas.

0 mecanismo envolvido na morte celular certamente se correlaciona ao mecanismo de ação que provoca essa miotoxicidade. Sabe-se que a morte celular induzida por sPLA2 também é associada com o aumento do influxo de $\mathrm{Ca}^{2+}$ através de canais de $\mathrm{Ca}^{2+}$ do tipo L sensíveis à voltagem (Yagami et al. 2003) e extresse oxidativo (Sun, Horrocks \& Farooqui, 2007) e que a atividade citotóxica de PLA2s cataliticamente ativas ou não, podem ser desencadeadas de maneira similar, como é o caso das frações purificadas de Bothrops jararacussu, 6-1 e 6-2 (variantes cataliticamente ativas, Asp49) e Bj-VII (uma variante Lys49 e portanto cataliticamente inativa), que apresentaram edema, miotoxicidade, redução da viabilidade de maneira similar (Bonfim et al., 2009).

A abolição da atividade enzimática em uma PLA2 isolada de Naja naja atra, por exemplo, não acabou completamente com a atividade citotóxica e o dano da membrana provocados em células U937, mostrando assim que a atividade catalítica não está fortemente correlacionada com a atividade citotóxica nessas enzimas. 0 tratamento dessas células por $24 \mathrm{~h}$ elevou os níveis de $\mathrm{Ca}^{2+}$ nas células, ativou seletivamente as vias JNK e p38 MAPK que, por sua vez, alterou a expressão de membros da família BCL-2. Em seguida, houve despolarização da membrana mitocondrial levando à liberação de citocromo c no citoplasma e ativação de caspase-3 e 9, culminando em apoptose (Liu et al., 2009).

No entanto, um estudo realizado por Murakami e seus colaboradores (2011), sugere que uma PLA2-Lys49 de Protobothrops flavoviridis (BPII) induz um tipo de morte celular única, de maneira independente de caspase e que apresenta tanto características de apoptose, tais como encolhimento celular, condensação nuclear e fragmentação de DNA, quanto características de necrose como a rápida exposição de 
PS e ruptura da membrana de plasma em células de leucemia humana. Segundo esse estudo, BPII possivelmente localiza as células por meio de receptores na superfície de sua MP, os quais já foram descritos anteriormente (Lambeau \& Lazdunski, 1999) ou mesmo por algum novo receptor ainda não descrito. Ou ainda por meio da interação direta das regiões catiônicas localizadas nas regiões C-terminais e Nterminais de BPII com algumas partes aniônicas de receptores causando uma interação eletrostática e perturbação da membrana, conforme relatado para a micotoxina II Bothrops asper (Lomonte et al., 2003).

\section{Expressão gênica X proteômica}

Wilmes e colaboradores (2013) investigaram o benefício da integração transcriptômica, proteômica e metabolômica em conjunto com a farmacocinética para regimes de testes de drogas. Nesse estudo, células renais epiteliais humanas cultivadas foram expostas à ciclosporina A (CsA), uma nefrotoxina durante 14 dias. 0 resultado mostra que todos os diferentes fluxos "ômicos" forneceram informações complementares, sendo alguns níveis de expressão gênica e de proteínas correlacionados, outros não. A correlação entre os resultados obtidos por diferentes técnicas também aumenta com o passar do tempo, sendo que o maior valor foi encontrado em 14 dias. 0 estudo demonstrou, pela primeira vez, que o estresse induzido por CsA não está diretamente ligado à sua farmacologia primária e também evidenciou o poder da integração de ciências "ômicas" para a elucidação das cascatas de sinalização.

As abordagens transcriptômica e proteômica de uma dada célula são complementares. Embora haja algumas diferenças, cada tecnologia fornece uma perspectiva única, bem como oportunidades para descobrir e interpretar eventos biológicos de maneira complementar, além de possibilitarem a realização de uma validação cruzada, cada uma apresentando vantagens distintas que podem envolver rendimento, cobertura, quantidade de amostra necessária e custo. Por outro lado, sabe-se que transcriptômica e proteômica não são equivalentes. 0 mRNA total em células ou tecidos em um determinado momento constitui seu transcriptoma, que após uma série de processamentos resultará no perfil proteômico. Todavia, alguns fatores já mencionados anteriormente entram em jogo durante a tradução do mRNA, tal como deterioração dos mRNAs em resposta a diferentes estímulos, tendo assim um profundo impacto sobre a quantidade de proteína sintetizada. Além disso, os 
eventos pós-traducionais aumentam a diversidade de proteínas que podem ser sintetizadas a partir de um número fixo de genes (Hegde et al., 2003).

Em relação aos resultados obtidos por expressão gênica e proteômica nesse estudo, é importante refletir sobre as semelhanças e diferenças na abundância de genes e proteínas. Como descrito anteriormente, apenas 16,6\% genes pertencentes às vias discutidas tiveram também seus produtos identificados na análise proteômica. Além disso, algumas níveis proteicos, que foram obtidos pelo tratamento das células com BmPLA2 por 24 horas estão correlacionados com os níveis de expressão gênica a $2 \mathrm{~h}$, outros no mesmo tempo, enquanto um terceiro grupo não está correlacionado de forma alguma.

Apesar de alguns dos resultados obtidos parecerem controversos, não estão em desacordo com outros trabalhos publicados, que também são muitas vezes de difícil análise. Por exemplo, um estudo realizado com leveduras submetidas a estresse por alterações de osmolaridade mostrou que em genes regulados positivamente, as concentrações máximas de mRNA e proteínas são bem correlacionados, mas esta tendência não se aplicava aos genes regulados negativamente (Lee et al., 2011).

Essa diferença entre a abundância de proteínas e mRNAs pode ser explicada por diversos fatores. Primeiramente, as relações entre as taxas de produção e degradação dessas moléculas podem variar significativamente, sendo que, em mamíferos, os mRNAs são produzidos a uma taxa muito mais baixa do que as proteínas. Em média, uma célula produz duas cópias de um determinado mRNA por hora, ao passo que produz dezenas de cópias da proteína correspondente por mRNA por hora. Outro fator seria a estabilidade. Os mRNAs são menos estáveis do que as proteínas, com uma meia-vida média de 2,6 a 7,0 horas versus 46 horas, respectivamente. As longas meias-vidas das proteínas podem também ocasionar um grande efeito de 'diluição', onde a concentração de proteínas cai devido à divisão celular.

Além disso, algumas proteínas terão sempre uma baixa correlação devido a diferenças individuais e influências de regulação traducional ou pós-traducional. Por exemplo, RNAs e proteínas pertencentes a processos metabólicos tendem a ser muito estáveis e terem altas taxas de proteína por mRNA, enquanto proteínas envolvidas na organização da cromatina e regulação transcricional tendem a ser 
rapidamente degradadas, ilustrando o fato de que proteínas regulatórias devem ser produzidas e degradadas rapidamente para reagir aos estímulos, enquanto proteínas estruturais e de processos permanentes são muito mais estáveis ( Vogel et al., 2010; Schwanhäusser et al., 2011). 
6. CONCLUSÕES E PERSPECTIVAS 


\section{CONCLUSÕES E PERSPECTIVAS}

As análises aqui realizadas com a peçonha de Bothrops marmoratus mostraram que sua atividade se dá de maneira diferente sobre linhagens celulares distintas, sugerindo uma ação seletiva sobre diferentes células. A combinação dos resultados mostram que a peçonha bruta age sobre as células não somente induzindo a necrose, mas interferindo com o ciclo celular e induzindo a apoptose.

A purificação da BmPLA2 foi realizada em apenas uma etapa cromatográfica em fase reversa. Tal toxina foi capaz de diminuir a viabilidade de células HeLa com baixo $\mathrm{IC}_{50}$, o que demonstra seu uso potencial como modelo para citotoxicidade e instiga a investigação mais detalhada sobre seu mecanismo de ação.

0 uso de técnicas que permitem uma análise global e sistemática como a trancriptômica e proteômica possibilitaram uma visão abrangente sobre as respostas e alterações evocadas nessas células e a detecção de alterações em diferentes vias biológicas, contribuindo para o entendimento do mecanismo de ação da BmPLA2.

Esse trabalho apresenta pela primeira vez o perfil de alterações transcriptômicas em células HeLa após o tratamento com uma PLA2 cataliticamente inativa. A técnica de microarranjo utilizada permitiu uma visão ampla sobre as alterações geradas ao longo do tempo e deixou claro que a BmPLA2 rapidamente induz mudanças substanciais no perfil gênico, com diversos genes apresentando variações expressivas em $2 \mathrm{~h}$, além de ativar diversas vias biológicas, tais como MAPK, adesão focal, autofagia e apoptose.

A estratégia conhecida como shotgun, na qual utiliza-se cromatografia líquida acoplada à espectrometria de massas (LC-MS) mostrou-se uma técnica útil para a identificação e quantificação relativa de proteínas envolvidas nos processos celulares ativados em resposta ao tratamento realizado nas células, contudo, não é conclusiva e necessita de confirmação por meio de outras técnicas. Apesar da baixa correlação entre proteínas e os genes obtidos por transcriptômica, a análise proteômica permitiu a identificação e quantificação relativa de diversas proteínas alteradas que participam de diferentes vias biológicas, incluindo vias que também mostraram-se alteradas na expressão gênica, tais como, adesão focal, autofagia e morte celular. 
Muito ainda deve ser esclarecido acerca da atividade citotóxica tanto da peçonha bruta quando da BmPLA2 isolada, especialmente dada a complexidade das respostas biológicas desencadeadas nas células tratadas com doses sub-letais de ambos. Todavia, tomados juntos, os resultados aqui apresentados constituem um rico banco de dados e contribuem para a compreensão dos efeitos da peçonha bruta de B. marmoratus, da BmPLA2 sobre células de câncer cervical (HeLa), bem como das respostas e mecanismos ativados nessas células frente ao estresse ao qual estão sendo submetidas. Pela primeira vez, uma análise comparativa da expressão diferenciada de genes e proteínas em células HeLa tratadas com uma PLA2 cataliticamente inativa é realizada.

Apesar de muitas das perguntas propostas terem sido respondidas, ainda é preciso confirmar a participação dessas vias por meio de ensaios de validação utilizando alguma tecnologia independente, como por exemplo, baseadas em anticorpos (western ou northern blots e ELISA), além de avançar no conhecimento sobre a atividade tanto de PLA2s, que podem ter uma importância tecnológica e comercial, quanto no conhecimento sobre o câncer e como esse tipo de células reage frente à fatores de estresse. 
7. BIBLIOGRAFIA 


\section{BIBLIOGRAFIA}

Agudo, Marta, Maria Cruz Pérez-Marín, Ulrika Lönngren, Paloma Sobrado, Ana Conesa, Isabel Cánovas, Manuel Salinas-Navarro, Jaime Miralles-Imperial, Finn Hallböök, and Manuel Vidal-Sanz. 2008. "Time Course Profiling of the Retinal Transcriptome after Optic Nerve Transection and Optic Nerve Crush." Molecular Vision 14 (April): 1050-63.

Alves, Raquel Melo, Gilmara Ausech Antonucci, Helder Henrique Paiva, A. C O Cintra, J. J. Franco, Elaine Paula Mendonça-Franqueiro, Daniel Junqueira Dorta, et al. 2008. "Evidence of Caspase-Mediated Apoptosis Induced by L-Amino Acid Oxidase Isolated from Bothrops Atrox Snake Venom." Comparative Biochemistry and Physiology - A Molecular and Integrative Physiology 151 (4): 542-50. doi:10.1016/j.cbpa.2008.07.007.

Amaral, A. 1925. "D0. 1923. New Genera and Species of Snakes." In Proc. New England Zool. Club, 8:85-105.

Ambjørn, Malene, Patrick Ejlerskov, Yawei Liu, Michael Lees, Marja Jäättelä, and Shohreh Issazadeh-Navikas. 2013. "IFNB1/interferon-B-Induced Autophagy in MCF-7 Breast Cancer Cells Counteracts Its Proapoptotic Function." Autophagy 9 (3): 287-302. doi:10.4161/auto.22831.

Andrews, R K, and M C Berndt. 2000. "Snake Venom Modulators of Platelet Adhesion Receptors and Their Ligands." Toxicon: Official Journal of the International $\begin{array}{lllll}\text { Society on } & \text { Toxinology } & 38 & \text { (6): }\end{array}$ http://www.ncbi.nlm.nih.gov/pubmed/10695965.

Andrews, R K, A S Kamiguti, O Berlanga, M Leduc, R D Theakston, and S P Watson. 2001. "The Use of Snake Venom Toxins as Tools to Study Platelet Receptors for Collagen and von Willebrand Factor." Haemostasis 31 (3-6): 155-72. doi:10.1159/000048059.

Andrews, RK K, AS S Kamiguti, O Berlanga, M Leduc, R D Theakston, and S P Watson. 2002. "The Use of Snake Venom Toxins as Tools to Study Platelet Receptors for Collagen and von Willebrand Factor." Haemostasis 31 (3-6): 155-72. doi:48059.

Aragão, Elisangela Aparecida. 2008. "Permeabilization of E. Coli K12 Inner and Outer Membranes by Bothropstoxin-I , A LYS49 Phospholipase A2 from Bothrops Jararacussu" 51: 538-46. doi:10.1016/j.toxicon.2007.11.004.

Ashwell, Jonathan D. 2006. "The Many Paths to p38 Mitogen-Activated Protein Kinase Activation in the Immune System." Nature Reviews. Immunology 6 (7): 532-40. doi:10.1038/nri1865.

Atsumi, G, M Tajima, a Hadano, Y Nakatani, M Murakami, and I Kudo. 1998. "FasInduced Arachidonic Acid Release Is Mediated by Ca2+-Independent Phospholipase A2 but Not Cytosolic Phospholipase A2, Which Undergoes 
Proteolytic Inactivation." The Journal of Biological Chemistry 273 (22): 1387077. http://www.ncbi.nlm.nih.gov/pubmed/9593733.

Azevedo Jr, W.F., R.J. Ward, F.R. Lombardi, J.R. Giglio, A.M. Soares, M.R.M. Fontes, and R.K. Arni. 1997. "Crystal Structure of Myotoxin-II: A Myotoxic Phospholipase A2-Homologue from Bothrops Moojeni Venom." Protein \& Peptide Letters 4 (5): 329-34.

Bazaa, Amine, José Luis, Najet Srairi-Abid, Olfa Kallech-Ziri, Raoudha KessentiniZouari, Céline Defilles, Jean-Claude Lissitzky, Mohamed El Ayeb, and Naziha Marrakchi. 2009. "MVL-PLA2, a Phospholipase A2 from Macrovipera Lebetina Transmediterranea Venom, Inhibits Tumor Cells Adhesion and Migration." Matrix Biology: Journal of the International Society for Matrix Biology 28 (4). Elsevier B.V./International Society of Matrix Biology: 188-93. doi:10.1016/j.matbio.2009.03.007.

Beavis, R C, and B T Chait. 1990. "High-Accuracy Molecular Mass Determination of Proteins Using Matrix-Assisted Laser Desorption Mass Spectrometry." Analytical Chemistry 62 (17): http://www.ncbi.nlm.nih.gov/pubmed/2240572.

Bergers, Gabriele, and Laura E Benjamin. 2003. "Tumorigenesis and the Angiogenic Switch." Nature Reviews. Cancer 3 (6): 401-10. doi:10.1038/nrc1093.

Bérnils, R. S., and H. C. (org.) Costa. 2012. "Répteis Brasileiros: Lista de Espécies." Sociedade Brasileira de Herpetologia.

Black, RA, CT Rauch, CJ Kozlosky, JJ Peschon, JL Slack, MF Wolfson, BJ Castner, et al. 1997. "A Metalloproteinase Disintegrin That Releases Tumour-Necrosis FactorAlpha from Cells." Nature 20;385 (6618): 729-33. http://www.ncbi.nlm.nih.gov/pubmed/9034190.

Bonfim, V. L., D. D. De Carvalho, L. a. Ponce-Soto, B. H. Kassab, and S. Marangoni. 2009. "Toxicity of Phospholipases A2 D49 (6-1 and 6-2) and K49 (Bj-VII) from Bothrops Jararacussu Venom." Cell Biology and Toxicology 25 (6): 523-32. doi:10.1007/s10565-008-9106-6.

Boschetti, E., and Pier Giorgio Righetti. 2013. "Introducing Low-Abundance Species in Proteome Analysis." In Low-Abundance Proteome Discovery, 1st ed., 1-11. Elsevier. doi:10.1016/B978-0-12-401734-4.09999-1.

Boyle, P., and B. Levin. 2008. World Cancer Report. Edited by Peter Boyle and Bernard Levin. Vol. 58. Lyon, France: World Health Organization. International Agency for Research on Cancer (IARC).

Bustillo, S, H Lucero, Leiva Lc, O Acosta, and Kier Joffé Eb. 2008. “April 10, 2008.” Journal of Venomous Animals and Toxins Including Tropical Diseases 15 (3400): 28-42. http://www.sciencedirect.com/science/article/pii/S004101010100229X. 
Bustillo, Soledad, Laura C Leiva, Luis Merino, Ofelia Acosta, Elisa Bal, De Kier Joffé, and Jorge 0 Gorodner. 2008. "Artemisa Antimicrobial Activity of Bothrops Alternatus Venom from the Northeast of Argentine."

Calderón, Leonel, and Bruno Lomonte. 1998. "Immunochemical Characterization and Role in Toxic Activities of Region 115-129 of Myotoxin II, a Lys49 Phospholipase A< Sub $>2<$ sub $>$ From $<$ I $>$ Bothrops Asper $<$ i $>$ Snake Venom." Archives of Biochemistry and Biophysics 358 (2). Elsevier: 343-50.

Camps, M, a Nichols, and S Arkinstall. 2000. "Dual Specificity Phosphatases: A Gene Family for Control of MAP Kinase Function." The FASEB Journal: Official Publication of the Federation of American Societies for Experimental Biology 14 (1): 6-16.

Carrasco, Paola A, Camilo I Mattoni, Gerardo C Leynaud, and Gustavo J Scrocchi. 2012. "Morphology , Phylogeny and Taxonomy of South American Bothropoid Pitvipers (Serpentes, Viperidae)," no. March: 109-24. doi:10.1111/j.14636409.2011.00511.x.

Chandramouli, Kondethimmanahalli, and Pei-Yuan Qian. 2009. "Proteomics: Challenges, Techniques and Possibilities to Overcome Biological Sample Complexity." Human Genomics and Proteomics: HGP 2009 (January). doi:10.4061/2009/239204.

Chechik, Gal, and Daphne Koller. 2009. "Timing of Gene Expression Responses to Environmental Changes." Journal of Computational Biology: A Journal of Computational Molecular Cell Biology $16 \quad$ (2): 279-90. doi:10.1089/cmb.2008.13TT.

Chen, Ping, Lixiang Wang, Na Li, Qiong Liu, and Jiazuan Ni. 2013. "Comparative Proteomics Analysis of Sodium Selenite-Induced Apoptosis in Human Prostate Cancer Cells." Metallomics: Integrated Biometal Science 5 (5): 541-50. doi:10.1039/c3mt00002h.

Chen, Xingyong, Ping Lv, Jing Liu, and Kangsen Xu. 2009. "Apoptosis of Human Hepatocellular Carcinoma Cell (HepG2) Induced by Cardiotoxin III through SPhase Arrest." Experimental and Toxicologic Pathology: Official Journal of the Gesellschaft Für Toxikologische Pathologie 61 (4): 307-15. doi:10.1016/j.etp.2008.09.006.

Chen, Zuojia, Joseph Barbi, Shurui Bu, Huang Yu Yang, Zhiyuan Li, Yayi Gao, Dilini Jinasena, et al. 2013. "The Ubiquitin Ligase stub1 Negatively Modulates Regulatory $\mathrm{T}$ Cell Suppressive Activity by Promoting Degradation of the Transcription Factor Foxp3." Immunity 39 (2): 272-85. doi:10.1016/j.immuni.2013.08.006.

Chijiwa, Takahito, Emi Tokunaga, Ryo Ikeda, Koki Terada, Tomohisa Ogawa, Naoko Oda-Ueda, Shosaku Hattori, Masatoshi Nozaki, and Motonori Ohno. 2006. "Discovery of Novel [Arg49] Phospholipase A2 Isozymes from Protobothrops Elegans Venom and Regional Evolution of Crotalinae Snake Venom 
Phospholipase A2 Isozymes in the Southwestern Islands of Japan and Taiwan." Toxicon 48 (6). Elsevier: 672-82.

Chung, Ching-Hu, Hui-Chin Peng, and Tur-Fu Huang. 2001. “Aggretin, a C-Type Lectin Protein, Induces Platelet Aggregation via Integrin $\alpha 2 \beta 1$ and GPIb in a Phosphatidylinositol 3-Kinase Independent Pathway." Biochemical and Biophysical Research Communications $285 \quad$ (3): 689-95. doi:http://dx.doi.org/10.1006/bbrc.2001.5228.

Clark, James D, Lih-Ling Lin, Ronald W Kriz, Chakkodabylu S Ramesha, Lisa A Sultzman, Alice Y Lin, Nina Milona, and John L Knopf. 1991. "A Novel Arachidonic Acid-Selective Cytosolic PLA2 Contains a Ca2+ -Dependent Translocation Domain with Homology to PKC and GAP." Cell 65 (6). Elsevier: 1043-51.

Cloutier, Philippe, Mathieu Lavallée-Adam, Denis Faubert, Mathieu Blanchette, and Benoit Coulombe. 2013. "A Newly Uncovered Group of Distantly Related Lysine Methyltransferases Preferentially Interact with Molecular Chaperones to Regulate Their Activity." PLoS Genetics 9 (1). doi:10.1371/journal.pgen.1003210.

Codogno, P, and A J Meijer. 2005. "Autophagy and Signaling: Their Role in Cell Survival and Cell Death." Cell Death and Differentiation 12 Suppl 2: 1509-18. doi:10.1038/sj.cdd.4401751.

Cohen, G M. 1997. "Caspases: The Executioners of Apoptosis.” The Biochemical Journal $326 \quad$ (August): 1-16. http://www.pubmedcentral.nih.gov/articlerender.fcgi?artid=1218630\&tool=p mcentrez\&rendertype $=$ abstract.

Costa, Tassia R., Danilo L. Menaldo, Clayton Z. Oliveira, Norival A. Santos-Filho, Sabrina S. Teixeira, Auro Nomizo, André L. Fuly, et al. 2008. "Myotoxic Phospholipases A2 Isolated from Bothrops Brazili Snake Venom and Synthetic Peptides Derived from Their C-Terminal Region: Cytotoxic Effect on Microorganism and Tumor Cells." Peptides 29 (10): 1645-56. http://www.sciencedirect.com/science/article/pii/S0196978108002441.

Creer, Simon, Anita Malhotra, Roger S Thorpe, Reto S Stöcklin, Philippe S Favreau, and Wen S Hao Chou. 2003. "Genetic and Ecological Correlates of Intraspecific Variation in Pitviper Venom Composition Detected Using Matrix-Assisted Laser Desorption Time-of-Flight Mass Spectrometry (MALDI-TOF-MS) and Isoelectric Focusing." Journal of Molecular Evolution 56 (3): 317-29. doi:10.1007/s00239002-2403-4.

Cummings, B S, J McHowat, and R G Schnellmann. 2000. "Phospholipase A(2)s in Cell Injury and Death." The Journal of Pharmacology and Experimental Therapeutics 294 (3): 793-99. http://www.ncbi.nlm.nih.gov/pubmed/10945826.

Cury, Yara, and Gisele Picolo. 2006. "Animal Toxins as Analgesics-An Overview." Drug News \& Perspectives 19 (7): 381. 
Cushman, D W, H S Cheung, E F Sabo, and M a Ondetti. 1977. "Design of Potent Competitive Inhibitors of Angiotensin-Converting Enzyme. Carboxyalkanoyl and Mercaptoalkanoyl Amino Acids." Biochemistry 16 (25): 5484-91. doi:10.1021/bi00644a014.

Cutler, Paul. 2003. "Protein Arrays: The Current State-of-the-Art." Proteomics 3 (1): 3-18. doi:10.1002/pmic.200390007.

Da Silva, Reinaldo J, Márcia G da Silva, Lízia C Vilela, and Denise Fecchio. 2002. "Antitumor Effect of Bothrops Jararaca Venom." Mediators of Inflammation. doi:10.1080/09629350220131953.

Daniele, J J, I D Bianco, C Delgado, D B Carrillo, and G D Fidelio. 1997. “A New Phospholipase A2 Isoform Isolated from Bothrops Neuwiedii (Yarará Chica) Venom with Novel Kinetic and Chromatographic Properties." Toxicon : Official Journal of the International Society on Toxinology 35 (8): 1205-15. http://www.sciencedirect.com/science/article/pii/s0041010197000238.

Daniele, J.J., I.D. Bianco, and G.D. Fidelio. 1995. "Kinetic and Pharmacological Characterization of Phospholipases A2 from Bothrops Neuwiedii Venom." Archives of Biochemistry and Biophysics 318 (1): 65-70. doi:10.1006/abbi.1995.1205.

Daniele, JJ, ID Bianco, and C Delgado. 1997. "A New Phospholipase a 2 Isoform Isolated from Bothrops Neuwiedii(yarará Chica) Venom with Novel Kinetic and Chromatographic Properties." Toxicon 0101 (97). http://www.sciencedirect.com/science/article/pii/S0041010197000238.

Davidson, Florence F, and Edward A Dennis. 1990. "Evolutionary Relationships and Implications for the Regulation of Phospholipase A2 from Snake Venom to Human Secreted Forms." Journal of Molecular Evolution 31 (3). Springer: 22838.

De Boer, Douwe, Annita M J Rousseau, Judith G J M Peulen, and Will K W H Wodzig. 2009. "Implications of Matrix Adducts to Protein Analyte Ions for SurfaceEnhanced Laser Desorption/ionization and Matrix-Assisted Laser Desorption/ionization Time-of-Flight Mass Spectrometric Analysis in Clinical Chemistry." Rapid Communications in Mass Spectrometry: RCM 23 (24): 404751. doi:10.1002/rcm.4304.

De Carvalho, D D, S Schmitmeier, J C Novello, and F S Markland. 2001. "Effect of BJcuL (a Lectin from the Venom of the Snake Bothrops Jararacussu) on Adhesion and Growth of Tumor and Endothelial Cells." Toxicon : Official Journal of the International Society on Toxinology 39 (10): 1471-76. http://www.ncbi.nlm.nih.gov/pubmed/11478954.

De Sousa Abreu, Raquel, Luiz O Penalva, Edward M Marcotte, and Christine Vogel. 2009. "Global Signatures of Protein and mRNA Expression Levels." Molecular bioSystems 5 (12): 1512-26. doi:10.1039/b908315d. 
Debouck, C, and P N Goodfellow. 1999. "DNA Microarrays in Drug Discovery and Development." Nature Genetics 21 (1 Suppl): 48-50. doi:10.1038/4475.

Delatorre, P, B a M Rocha, T Santi-Gadelha, C a a Gadelha, M H Toyama, and B S Cavada. 2010. "Crystal Structure of Bn IV in Complex with Myristic Acid: A Lys49 Myotoxic Phospholipase $A_{2}$ from Bothrops Neuwiedi Venom." Biochimie 93 (3): 513-18. doi:10.1016/j.biochi.2010.11.003.

Delgado, M a, and V Deretic. 2009. "Toll-like Receptors in Control of Immunological Autophagy." Cell Death and Differentiation 16 (7). Nature Publishing Group: 976-83. doi:10.1038/cdd.2009.40.

Deluca, Mariagrazia, Christopher M Ward, Keizo Ohmori, Robert K Andrews, and Michael C Berndt. 1995. "Jararhagin and Jaracetin: Novel Snake Venom Inhibitors of the Integrin Collagen Receptor, $\alpha 2 \beta 1$." Biochemical and Biophysical Research Communications 206 (2). Elsevier: 570-76.

Denmeade, SR, and JT Isaacs. 1996. "Programmed Cell Death (Apoptosis) and Cancer Chemotherapy." Cancer Control : Journal of the Moffitt Cancer Center 3 (4): 3039. http://www.ncbi.nlm.nih.gov/pubmed/10765221.

Dondelinger, Yves, Wim Declercq, Sylvie Montessuit, Ria Roelandt, Amanda Goncalves, Inge Bruggeman, Paco Hulpiau, et al. 2014. "MLKL Compromises Plasma Membrane Integrity by Binding to Phosphatidylinositol Phosphates." Cell Reports 7 (4): 971-81. doi:10.1016/j.celrep.2014.04.026.

Du, X. Y., Alexey Navdaev, J. M. Clemetson, Edith Magnenat, Timothy N C Wells, and Kenneth J Clemetson. 2001. "Bilinexin, a Snake C-Type Lectin from Agkistrodon Bilineatus Venom Agglutinates Platelets via GPIb and $\alpha 2 \beta 1$." Thrombosis and Haemostasis 86 (5): 1277-83.

Edinger, Aimee L., and Craig B. Thompson. 2004. "Death by Design: Apoptosis, Necrosis and Autophagy." Current Opinion in Cell Biology 16 (6): 663-69. doi:10.1016/j.ceb.2004.09.011.

Fenwick, Allyson M, Ronald L Gutberlet Jr, Jennafer A Evans, and Christopher L Parkinson. 2009. "Morphological and Molecular Evidence for Phylogeny and Classification of South American Pitvipers, Genera Bothrops, Bothriopsis, and Bothrocophias ( Serpentes: Viperidae )." Zoological Journal of the Linnean Society, 617-40.

Ferlay, Jacques, Hai-Rim Shin, Freddie Bray, David Forman, Colin Mathers, and Donald Maxwell Parkin. 2010. "Estimates of Worldwide Burden of Cancer in 2008: GLOBOCAN 2008." International Journal of Cancer. Journal International Du Cancer 127 (12): 2893-2917. doi:10.1002/ijc.25516.

Ferreira, FB, RS Rodrigues, Thomas Cardoso, and VMR Ávila. 2008. "Caracterização Química, Enzimática E Citotóxica de Uma Fosfolipase A2 Ácida Isolada Da Peçonha de Bothrops Paulosensis," 1-10. 
https://ssl4799.websiteseguro.com/swge5/seg/cd2008/PDF/IC20080145.PDF.

Ferreira, L A, A Galle, M Raida, M Schrader, I Lebrun, and G Habermehl. 1998. "Isolation: Analysis and Properties of Three Bradykinin-Potentiating Peptides (BPP-II, BPP-III, and BPP-V) from Bothrops Neuwiedi Venom." Journal of $\begin{array}{llll}\text { Protein } & \text { Chemistry } & 17 & \text { (3): }\end{array}$ http://www.springerlink.com/index/w22xw88674502p87.pdf.

Ferreira, S. H. 1965. "A Bradykinin-Potentiating Factor (bpf) Present in the Venom of Bothrops Jararaca." British Journal of Pharmacology and Chemotherapy 24 (1): 163-69. doi:10.1111/j.1476-5381.1965.tb02091.x.

Ferreira, Sergio H., Diana C Bartelt, and Lewis J. Greene. 1970. "Isolation of Bradykinin-Potentiating Peptides from Bothrops Jararaca Venom." Biochemistry 9 (13): 2583-93. doi:10.1021/bi00815a005.

Fine, S. W., M. P. Lisanti, F. Galbiati, and M. Li. 2001. "Elevated Expression of Caveolin-1 in Adenocarcinoma of the Colon." American Journal of Clinical Pathology 115 (5): 719-24. doi:10.1309/YL54-CCU7-4V0P-FDUT.

Fleischer, Aarne, Ata Ghadiri, Frédéric Dessauge, Marianne Duhamel, Maria Paz Rebollo, Fernando Alvarez-Franco, and Angelita Rebollo. 2006. "Modulating Apoptosis as a Target for Effective Therapy." Molecular Immunology 43 (8): 1065-79. doi:10.1016/j.molimm.2005.07.013.

Florens, Laurence, and Michael P Washburn. 2006. "Proteomic Analysis by Multidimensional Protein Identification Technology." Methods in Molecular Biology (Clifton, N.J.) 328: 159-75. doi:10.1385/1-59745-026-X:159.

Foster, Irene. 2008. "Cancer: A Cell Cycle Defect," 144-49. doi:10.1016/j.radi.2006.12.001.

Fox, Jay W, and Solange M T Serrano. 2007. “Approaching the Golden Age of Natural Product Pharmaceuticals from Venom Libraries: An Overview of Toxins and Toxin-Derivatives Currently Involved in Therapeutic or Diagnostic Applications." Current Pharmaceutical Design 13 (28): 2927-34. http://www.ncbi.nlm.nih.gov/pubmed/17979737.

Frisch, S M, and H Francis. 1994. "Disruption of Epithelial Cell-Matrix Interaction Induces Apoptosis.” J. Cell. Biol. 124 (4): 619-26.

Frisch, Steven M, Michael Schaller, and Benjamin Cieply. 2013. "Mechanisms That Link the Oncogenic Epithelial-Mesenchymal Transition to Suppression of Anoikis." Journal of Cell Science 126 (Pt 1): 21-29. doi:10.1242/jcs.120907.

Fujimura, Yoshihiro, Koiti Titani, Yoshiko Usami, Masami Suzuki, Rieko Oyama, Taei Matsui, Hiromu Fukui, Mitsuhiko Sugimoto, and Zaverio M Ruggeri. 1991. "Isolation and Chemical Characterization of Two Structurally and Functionally 
Distinct Forms of Botrocetin, the Platelet Coagglutinin Isolated from the Venom of Bothrops Jararaca." Biochemistry 30 (7). ACS Publications: 1957-64.

Fulda, S, and K-M Debatin. 2006. "Extrinsic versus Intrinsic Apoptosis Pathways in Anticancer Chemotherapy." Oncogene 25 (34): 4798-4811. doi:10.1038/sj.onc.1209608.

Fung, E. T. 2005. "Inadequate Attempts to Measure the Microheterogeneity of Transthyretin by Low-Resolution Mass Spectrometry - Reply." Clinical Chemistry 51 (7): 1300-1300. doi:10.1373/clinchem.2005.050971.

Gabrielli, Brian, Kelly Brooks, and Sandra Pavey. 2012. "Defective Cell Cycle Checkpoints as Targets for Anti-Cancer Therapies." Frontiers in Pharmacology 3 (February): 9. doi:10.3389/fphar.2012.00009.

Gallagher, Paul G, Yongde Bao, Solange M T Serrano, Aura S Kamiguti, R David G Theakston, and Jay W Fox. 2003. "Use of Microarrays for Investigating the Subtoxic Effects of Snake Venoms: Insights into Venom-Induced Apoptosis in Human Umbilical Vein Endothelial Cells." Toxicon: Official Journal of the International Society on Toxinology 41 (4): 429-40. http://www.ncbi.nlm.nih.gov/pubmed/12657312.

Galluzzi, L, I Vitale, J M Abrams, E S Alnemri, E H Baehrecke, M V Blagosklonny, T M Dawson, et al. 2012. "Molecular Definitions of Cell Death Subroutines: Recommendations of the Nomenclature Committee on Cell Death 2012." Cell Death and Differentiation 19 (1): 107-20. doi:10.1038/cdd.2011.96.

Galluzzi, Lorenzo, and Guido Kroemer. 2008. "Necroptosis: A Specialized Pathway of Programmed Necrosis.” Cell 135 (7): 1161-63. doi:10.1016/j.cell.2008.12.004.

Gebrim, Luiz Carlos, Silvana Marcussi, Danilo L Menaldo, Carla S R de Menezes, Auro Nomizo, Amélia Hamaguchi, Elisângela P Silveira-Lacerda, et al. 2009. "Antitumor Effects of Snake Venom Chemically Modified Lys49 Phospholipase A2-like BthTX-I and a Synthetic Peptide Derived from Its C-Terminal Region." Biologicals : Journal of the International Association of Biological Standardization 37 (4): 222-29. doi:10.1016/j.biologicals.2009.01.010.

Green, DR, and Beth Levine. 2014. "To Be or Not to Be? How Selective Autophagy and Cell Death Govern Cell Fate." Cell, no. Figure 1: 65-75. http://www.sciencedirect.com/science/article/pii/S0092867414002943.

Gross, Atan, Xiao Ming Yin, Kun Wang, Michael C. Wei, Jennifer Jockel, Curt Milliman, Hediye Erdjument-Bromage, Paul Tempst, and Stanley J. Korsmeyer. 1999. "Caspase Cleaved BID Targets Mitochondria and Is Required for Cytochrome c Release, While BCL-X(L) Prevents This Release but Not Tumor Necrosis FactorR1/Fas Death." Journal of Biological Chemistry 274 (2): 1156-63. doi:10.1074/jbc.274.2.1156.

Gross, Richard W, Sasanka Ramanadham, Kelly K Kruszka, Xianlin Han, and John Turk. 1993. "Rat and Human Pancreatic Islet Cells Contain a Calcium Ion 
Independent Phospholipase A2 Activity Selective for Hydrolysis of Arachidonate Which Is Stimulated by Adenosine Triphosphate and Is Specifically Localized to Islet. Beta.-Cells." Biochemistry 32 (1). ACS Publications: 327-36.

Gutiérrez, José María. 2002. “Comprendiendo Los Venenos de Serpientes: 50 Años de Investigaciones En América Latina.” Revista de Biología Tropical 50 (2).

Gygi, S P, B Rist, S A Gerber, F Turecek, M H Gelb, and R Aebersold. 1999. "Quantitative Analysis of Complex Protein Mixtures Using Isotope-Coded Affinity Tags." Nature Biotechnology 17 (10): 994-99. doi:10.1038/13690.

Gygi, S P, Y Rochon, B R Franza, and R Aebersold. 1999. "Correlation between Protein and mRNA Abundance in Yeast." Molecular and Cellular Biology 19 (3): 1720-30.

Haataja, Leena, John Groffen, and Nora Heisterkamp. 1997. "Characterization of RAC3, a Novel Member of the Rho Family." Journal of Biological Chemistry 272 (33): 20384-88. doi:10.1074/jbc.272.33.20384.

Hanahan, D, and R A Weinberg. 2000. "The Hallmarks of Cancer." Cell 100 (1). Springer Berlin / Heidelberg: 57-70. doi:10.1007/s00262-010-0968-0.

Hanahan, Douglas, and Robert A Weinberg. 2011. "Review Hallmarks of Cancer: The Next Generation.” Cell 144 (5). Elsevier Inc.: 646-74. doi:10.1016/j.cell.2011.02.013.

Hartwell, L., and M. Kastan. 1994. "Cell Cycle Control and Cancer." Science 266 (5192): 1821-28. doi:10.1126/science.7997877.

Hazen, Stanley L, D A Ford, and R W Gross. 1991. "Activation of a MembraneAssociated Phospholipase A2 during Rabbit Myocardial Ischemia Which Is Highly Selective for Plasmalogen Substrate." Journal of Biological Chemistry 266 (9). ASBMB: 5629-33.

Hegde, Priti S., Ian R. White, and Christine Debouck. 2003. "Interplay of Transcriptomics and Proteomics." Current Opinion in Biotechnology 14 (6): 647-51. doi:10.1016/j.copbio.2003.10.006.

Heinrikson, ROBERT L, ELAINE T Krueger, and PAMELA S Keim. 1977. “Amino Acid Sequence of Phospholipase A2-Alpha from the Venom of Crotalus Adamanteus. A New Classification of Phospholipases A2 Based upon Structural Determinants." Journal of Biological Chemistry 252 (14). ASBMB: 4913-21.

Hernández Cruz, a, S Garcia-Jimenez, R Zucatelli Mendonça, and V L Petricevich. 2008. "Pro- and Anti-Inflammatory Cytokines Release in Mice Injected with Crotalus Durissus Terrificus Venom." Mediators of Inflammation 2008 (January): 874962. doi:10.1155/2008/874962. 
Hitoshi, Yasumichi, James Lorens, Shin Ichi Kitada, Joan Fisher, Mark LaBarge, Huijun Z. Ring, Uta Francke, John C. Reed, Shigemi Kinoshita, and Garry P. Nolan. 1998. "Toso, a Cell Surface, Specific Regulator of Fas-Induced Apoptosis in T Cells." Immunity 8 (4): 461-71. doi:10.1016/S1074-7613(00)80551-8.

Horii, Katsunori, Daiju Okuda, Takashi Morita, and Hiroshi Mizuno. 2003. "Structural Characterization of EMS16, an Antagonist of Collagen Receptor (GPIa/IIa) from the Venom of Echis Multisquamatus." Biochemistry 42 (43). ACS Publications: 12497-502.

Houtgraaf, Jaco H, Jorie Versmissen, and Wim J van der Giessen. 2006. "A Concise Review of DNA Damage Checkpoints and Repair in Mammalian Cells." Cardiovascular Revascularization Medicine: Including Molecular Interventions 7 (3): 165-72. doi:10.1016/j.carrev.2006.02.002.

Huang, Da Wei, Brad T Sherman, and Richard a Lempicki. 2009. "Systematic and Integrative Analysis of Large Gene Lists Using DAVID Bioinformatics Resources." Nature Protocols. doi:10.1038/nprot.2008.211.

Instituto Nacional de Câncer José Alencar Gomes da Silva, INCA. 2014. "Estimativa 2014: Incidência de Câncer No Brasil.” Rio de Janeiro. http://www.inca.gov.br/estimativa/2014/index.asp?ID=1.

Janicke, R. U. 1998. "Caspase-3 Is Required for DNA Fragmentation and Morphological Changes Associated with Apoptosis." Journal of Biological Chemistry 273 (16): 9357-60. doi:10.1074/jbc.273.16.9357.

Ji, Y B, S Y Gao, C F Ji, and X Zou. 2008. "Induction of Apoptosis in HepG2 Cells by Solanine and Bcl-2 Protein." Journal of Ethnopharmacology 115 (2): 194-202. doi:10.1016/j.jep.2007.09.023.

Jounai, Nao, Fumihiko Takeshita, Kouji Kobiyama, Asako Sawano, Atsushi Miyawaki, Ke-Qin Xin, Ken J Ishii, et al. 2007. "The Atg5 Atg12 Conjugate Associates with Innate Antiviral Immune Responses." Proceedings of the National Academy of Sciences of the United States of America 104 (35): 14050-55. doi:10.1073/pnas.0704014104.

Junttila, M R, R Ala-Aho, T Jokilehto, J Peltonen, M Kallajoki, R Grenman, P Jaakkola, J Westermarck, and V-M Kähäri. 2007. "p38alpha and p38delta MitogenActivated Protein Kinase Isoforms Regulate Invasion and Growth of Head and Neck Squamous Carcinoma Cells." Oncogene 26 (36): 5267-79. doi:10.1038/sj.onc.1210332.

Junttila, Melissa R, Song-Ping Li, and Jukka Westermarck. 2008. "PhosphataseMediated Crosstalk between MAPK Signaling Pathways in the Regulation of Cell Survival." The FASEB Journal : Official Publication of the Federation of American Societies for Experimental Biology 22 (4): 954-65. doi:10.1096/fj.06-7859rev. 
Kamiguti, A, C Hay, and Mirko Zuzel. 1996. "Inhibition of Collagen-Induced Platelet Aggregation as the Result of Cleavage of Alpha 2 Beta 1-Integrin by the Snake Venom Metalloproteinase Jararhagin." Biochem. J 320: 635-41.

Kamiguti, A S, M Zuzel, and R D G Theakston. 1998. "Snake Venom Metalloproteinases and Disintegrins: Interactions with Cells." Brazilian Journal of Medical and Biological Research 31 (7). SciELO Brasil: 853-62.

Kaneko, Tomoatsu, Zhaocheng Zhang, Maria G. Mantellini, Elisabeta Karl, Benjamin Zeitlin, Monique Verhaegen, María S. Soengas, et al. 2007. "Bcl-2 Orchestrates a Cross-Talk between Endothelial and Tumor Cells That Promotes Tumor Growth." Cancer Research 67 (20): 9685-93. doi:10.1158/0008-5472.CAN-071497.

Kanzawa, T, I M Germano, T Komata, H Ito, Y Kondo, and S Kondo. 2004. "Role of Autophagy in Temozolomide-Induced Cytotoxicity for Malignant Glioma Cells." Cell Death and Differentiation 11 (4): 448-57. doi:10.1038/sj.cdd.4401359.

Kanzawa, Takao, Yasuko Kondo, Hideaki Ito, Seiji Kondo, and Isabelle Germano. 2003. "Induction of Autophagic Cell Death in Malignant Glioma Cells by Arsenic Trioxide." Cancer Research 63 (9): 2103-8.

Kastan, Michael B, and Jiri Bartek. 2004. "Cell-Cycle Checkpoints and Cancer." Nature 432 (7015): 316-23. doi:10.1038/nature03097.

Kearney, P, and P Thibault. 2003. "Bioinformatics Meets Proteomics--Bridging the Gap between Mass Spectrometry Data Analysis and Cell Biology." Journal of Bioinformatics and Computational Biology 1 (1): 183-200.

Kerr, JFR, AH Wyllie, and AR Currie. 1972. "Apoptosis: A Basic Biological Phenomenon with Wide-Ranging Implications in Tissue Kinetics." British Journal of Cancer. http://www.ncbi.nlm.nih.gov/pmc/articles/PMC2008650/.

Keyse, Stephen M. 2008. "Dual-Specificity MAP Kinase Phosphatases (MKPs) and Cancer." Cancer and Metastasis Reviews 27 (2): 253-61. doi:10.1007/s10555008-9123-1.

Khunsap, Suchitra, Narumol Pakmanee, Orawan Khow, Lawan Chanhome, Visith Sitprija, Montamas Suntravat, Sara E Lucena, John C Perez, and Elda E Sánchez. 2011. "Purification of a Phospholipase A(2) from Daboia Russelii Siamensis Venom with Anticancer Effects." Journal of Venom Research 2 (January): 42-51. http://www.pubmedcentral.nih.gov/articlerender.fcgi?artid=3210966\&tool=p mcentrez\&rendertype=abstract.

Kim, Yong Nyun, Kyung Hee Koo, Jee Young Sung, Un Jung Yun, and Hyeryeong Kim. 2012. "Anoikis Resistance: An Essential Prerequisite for Tumor Metastasis." International Journal of Cell Biology 2012. doi:10.1155/2012/306879.

Kinase, Signal-regulated Kinase, Song-ping Li, Melissa R Junttila, Jiahuai Han, and Veli-matti Ka. 2003. "Advances in Brief p38 Mitogen-Activated Protein Kinase 
Pathway Suppresses Cell Survival by Inducing Dephosphorylation of MitogenActivated Protein / Extracellular," 3473-77.

King, Glenn F. 2011. "Venoms as a Platform for Human Drugs: Translating Toxins into Therapeutics." Expert Opinion on Biological Therapy 11 (11): 1469-84. doi:10.1517/14712598.2011.621940.

Kini, R M. 1997. "Phospholipase A2-a Complex Multifunctional Protein Puzzle." Venom Phospholipase A2 Enzymes: Structure, Function and Mechanism. John Wiley \& Sons Chichester, England, 1-28.

Klionsky, DJ, et al. 2012. "Guidelines for the Use and Interpretation of Assays for Monitoring Autophagy." Autophagy 8 (2): 445-544. doi:10.4161/auto.19496.

Klose, Joachim, Christina Nock, Marion Herrmann, Kai Stühler, Katrin Marcus, Martin Blüggel, Eberhard Krause, et al. 2002. "Genetic Analysis of the Mouse Brain Proteome." Nature Genetics 30 (4): 385-93. doi:10.1038/ng861.

Kominsky, Scott L. 2006. "Claudins: Emerging Targets for Cancer Therapy.” Expert Reviews in Molecular Medicine 8 (18): 1-11. doi:10.1017/S1462399406000056.

Kouroku, Y, E Fujita, I Tanida, T Ueno, a Isoai, H Kumagai, S Ogawa, R J Kaufman, E Kominami, and T Momoi. 2007. "ER Stress (PERK/eIF2alpha Phosphorylation) Mediates the Polyglutamine-Induced LC3 Conversion, an Essential Step for Autophagy Formation." Cell Death and Differentiation 14 (2): 230-39. doi:10.1038/sj.cdd.4401984.

Kroemer, Guido, and Beth Levine. 2008. "Autophagic Cell Death: The Story of a Misnomer." Nature Reviews. Molecular Cell Biology 9 (12): 1004-10. doi:10.1038/nrm2529.

Kroemer, Guido, Guillermo Mariño, and Beth Levine. 2010. "Autophagy and the Integrated Stress Response.” Molecular Cell 40 (2): 280-93. doi:10.1016/j.molcel.2010.09.023.

Laezza, Chiara, Simona Pisanti, Elvira Crescenzi, and Maurizio Bifulco. 2006. "Anandamide Inhibits Cdk2 and Activates Chk1 Leading to Cell Cycle Arrest in Human Breast Cancer Cells." FEBS Letters 580 (26): 6076-82. doi:10.1016/j.febslet.2006.09.074.

Lambeau, G. Érard, and Michel Lazdunski. 1999. "Receptors for a Growing Family of Secreted Phospholipases A2." Trends in Pharmacological Sciences 20 (4): 16270. doi:10.1016/S0165-6147(99)01300-0.

Lamparska-Przybysz, M., B. Gajkowska, and T. Motyl. 2005. "Cathepsins and Bid Are Involved in the Molecular Switch between Apoptosis and Autophagy in Breast Cancer MCF-7 Cells Exposed to Camptothecin." Journal of Physiology and Pharmacology 56 (SUPPL. 3): 159-79. doi:16077201. 
Lazebnik, Yuri A., Susan Cole, Carol A. Cooke, William G. Nelson, and William C. Earnshaw. 1993. "Nuclear Events of Apoptosis in Vitro in Cell-Free Mitotic Extracts: A Model System for Analysis of the Active Phase of Apoptosis." Journal of Cell Biology 123 (1): 7-22. doi:10.1083/jcb.123.1.7.

Lee, M Violet, Scott E Topper, Shane L Hubler, James Hose, Craig D Wenger, Joshua J Coon, and Audrey P Gasch. 2011. "A Dynamic Model of Proteome Changes Reveals New Roles for Transcript Alteration in Yeast." Molecular Systems Biology 7: 514. doi:10.1038/msb.2011.48.

Lee, Nikki P., and John M. Luk. 2010. "Hepatic Tight Junctions: From Viral Entry to Cancer Metastasis." World Journal of Gastroenterology. doi:10.3748/wjg.v16.i3.289.

Lehman, John J, Kathryn A Brown, SASANKA Ramanadham, John Turk, and Richard W Gross. 1993. "Arachidonic Acid Release from Aortic Smooth Muscle Cells Induced by [Arg8] Vasopressin Is Largely Mediated by Calcium-Independent Phospholipase A2." Journal of Biological Chemistry 268 (28). ASBMB: 20713-16.

Levenson, Anait S, and V Craig Jordan. 1997. "MCF-7: The First HormoneResponsive Breast Cancer Cell Line MCF-7: The First Hormone-Responsive Breast Cancer Cell Line '," 3071-78.

Li, Chaoying, Daryl A Scott, Ekaterina Hatch, Xiaoyan Tian, and Suzanne L Mansour. 2007. "Dusp6 (Mkp3) Is a Negative Feedback Regulator of FGF-Stimulated ERK Signaling during Mouse Development." Development (Cambridge, England) 134 (1): 167-76. doi:10.1242/dev.02701.

Li, Jixi, Thomas McQuade, Ansgar B. Siemer, Johanna Napetschnig, Kenta Moriwaki, Yu Shan Hsiao, Ermelinda Damko, et al. 2012. "The RIP1/RIP3 Necrosome Forms a Functional Amyloid Signaling Complex Required for Programmed Necrosis." Cell 150 (2): 339-50. doi:10.1016/j.cell.2012.06.019.

Li, P, D Nijhawan, I Budihardjo, S M Srinivasula, M Ahmad, E S Alnemri, and X Wang. 1997. "Cytochrome c and dATP-Dependent Formation of Apaf-1/caspase-9 Complex Initiates an Apoptotic Protease Cascade." Cell 91 (4): 479-89. doi:10.1016/S0092-8674(00)80434-1.

Lin, Shuw-Yuan, Wan-Wen Lai, Chi-Chung Chou, Hsiu-Maan Kuo, Te-Mao Li, JingGung Chung, and Jen-Hung Yang. 2006. "Sodium Ascorbate Inhibits Growth via the Induction of Cell Cycle Arrest and Apoptosis in Human Malignant Melanoma A375.S2 Cells." Melanoma Research 16 (6): 509-19. doi:10.1097/01.cmr.0000232297.99160.9e.

Listgarten, Jennifer, and Andrew Emili. 2005. "Statistical and Computational Methods for Comparative Proteomic Profiling Using Liquid ChromatographyTandem Mass Spectrometry." Molecular \& Cellular Proteomics : MCP 4 (4): 41934. doi:10.1074/mcp.R500005-MCP200. 
Liu, Chao-Zong, and Tur-Fu Huang. 1997. "Crovidisin, a Collagen-Binding Protein Isolated from Snake Venom of $<$ I $>$ Crotalus Viridis, $</ \mathrm{i}>$ Prevents PlateletCollagen Interaction." Archives of Biochemistry and Biophysics 337 (2). Elsevier: 291-99.

Liu, Wen-Hsin, Pei-Hsiu Kao, Yi-Ling Chiou, Shinne-Ren Lin, Ming-Jung Wu, and Long-Sen Chang. 2009. "Catalytic Activity-Independent Pathway Is Involved in Phospholipase A(2)-Induced Apoptotic Death of Human Leukemia U937 Cells via $\mathrm{Ca}(2+)-M e d i a t e d$ p38 MAPK Activation and Mitochondrial Depolarization." Toxicology Letters 185 (2): 102-9. doi:10.1016/j.toxlet.2008.12.004.

Liu, X, P Li, P Widlak, H Zou, X Luo, W T Garrard, and X Wang. 1998. "The 40-kDa Subunit of DNA Fragmentation Factor Induces DNA Fragmentation and Chromatin Condensation during Apoptosis." Proceedings of the National Academy of Sciences of the United States of America 95 (15): 8461-66. doi:10.1073/pnas.95.15.8461.

Liu, Yuangang, James Lagowski, Aaron Sundholm, Alexandra Sundberg, and Molly Kulesz-Martin. 2007. "Microtubule Disruption and Tumor Suppression by Mitogen-Activated Protein Kinase Phosphatase 4." Cancer Research 67 (22): 10711-19. doi:10.1158/0008-5472.CAN-07-1968.

Lo, Su Hao. 2006. "Focal Adhesions: What's New inside." Developmental Biology 294 (2): 280-91. doi:10.1016/j.ydbio.2006.03.029.

Lomonte, Bruno, Yamileth Angulo, and Leonel Calderón. 2003. "An Overview of Lysine-49 Phospholipase A2 Myotoxins from Crotalid Snake Venoms and Their Structural Determinants of Myotoxic Action." Toxicon 42 (8): 885-901. doi:10.1016/j.toxicon.2003.11.008.

Long, J S, and K M Ryan. 2012. "New Frontiers in Promoting Tumour Cell Death: Targeting Apoptosis, Necroptosis and Autophagy." Oncogene 31 (49). Nature Publishing Group: 5045-60. doi:10.1038/onc.2012.7.

Louis, Emily, Ulrika Raue, Yifan Yang, Bozena Jemiolo, and Scott Trappe. 2007. "Time Course of Proteolytic, Cytokine, and Myostatin Gene Expression after Acute Exercise in Human Skeletal Muscle" 47306: 1744-51. doi:10.1152/japplphysiol.00679.2007.

Lukas, Jiri, Claudia Lukas, and Jiri Bartek. 2004. "Mammalian Cell Cycle Checkpoints: Signalling Pathways and Their Organization in Space and Time." DNA Repair 3 (8-9): 997-1007. doi:10.1016/j.dnarep.2004.03.006.

Macêdo, Jessica Kele Arruda. 2011. “ANÁLISE DA PEÇONHA DE Bothropoides Marmoratus, COM ÊNFASE NA CARACTERIZAÇÃO DE PROTEÍNAS COM ATIVIDADE ANTIMICROBIANA E/OU ANTITUMORAL." Universidade de Brasília. http://hdl.handle.net/10482/8774.

Machado, T. 2010. "Filogenia Molecular Das Espécies de Bothrops Do Grupo Neuwiedi (Serpentes, Viperidae)." Universidade de São Paulo (USP). 
Mailleux, Arnaud A., Michael Overholtzer, Tobias Schmelzle, Philippe Bouillet, Andreas Strasser, and Joan S. Brugge. 2007. "BIM Regulates Apoptosis during Mammary Ductal Morphogenesis, and Its Absence Reveals Alternative Cell Death Mechanisms." Developmental Cell 12 (2): 221-34. doi:10.1016/j.devcel.2006.12.003.

Mancin, Adriana C., Andreimar M. Soares, Silvia H. Andrião-Escarso, Vitor M. Faça, Lewis J. Greene, Sérgio Zuccolotto, Irene R. Pela, and José R. Giglio. 1998. "The Analgesic Activity of Crotamine, a Neurotoxin from Crotalus Durissus Terrificus (South American Rattlesnake) Venom: A Biochemical and Pharmacological Study." Toxicon 36 (12): 1927-37. doi:10.1016/S0041-0101(98)00117-2.

Markland, Francis S. 1998. "Snake Venoms and the Hemostatic System." Toxicon 36 (12). Elsevier: 1749-1800.

Martin, S J, C P Reutelingsperger, a J McGahon, J a Rader, R C van Schie, D M LaFace, and D R Green. 1995. "Early Redistribution of Plasma Membrane Phosphatidylserine Is a General Feature of Apoptosis regardless of the Initiating Stimulus: Inhibition by Overexpression of Bcl-2 and Abl." The Journal of Experimental Medicine 182 (5): 1545-56. doi:10.1084/jem.182.5.1545.

Masuda, S, S Araki, T Yamamoto, K Kaji, and H Hayashi. 1997. "Purification of a Vascular Apoptosis-Inducing Factor from Hemorrhagic Snake Venom." Biochemical and Biophysical Research Communications 235 (1). Elsevier: 59-63.

Masuda, Shinako, Hiroshi Hayashi, and Satohiko Araki. 1998. "Two Vascular Apoptosis Inducing Proteins from Snake Venom Are Members of the Metalloprotease/disintegrin Family." European Journal of Biochemistry 253 (1). Wiley Online Library: 36-41.

Matsui, T, Y Fujimura, and K Titani. 2000. "Snake Venom Proteases Affecting Hemostasis and Thrombosis." Biochimica et Biophysica Acta 1477 (1-2): 14656. http://www.ncbi.nlm.nih.gov/pubmed/10708855.

McCarthy, Nicola J., Moira K B Whyte, Christopher S. Gilbert, and Gerard I. Evan. 1997. "Inhibition of Ced-3/ICE-Related Proteases Does Not Prevent Cell Death Induced by Oncogenes, DNA Damage, or the Bcl-2 Homologue Bak." Journal of Cell Biology 136 (1): 215-27. doi:10.1083/jcb.136.1.215.

McCleary, Ryan J.R., and R. Manjunatha Kini. 2013. "Non-Enzymatic Proteins from Snake Venoms: A Gold Mine of Pharmacological Tools and Drug Leads." Toxicon 62 (February): 56-74. doi:10.1016/j.toxicon.2012.09.008.

McIntosh, J Michael, Farideh Ghomashchi, Michael H Gelb, David J Dooley, Sally J Stoehr, Anne B Giordani, Scott R Naisbitt, and Baldomero M Olivera. 1995. "Conodipine-M, a Novel Phospholipase A Isolated from the Venom of the Marine Snail Conus Magus.” Journal of Biological Chemistry 270 (8). ASBMB: 3518-26.

McKay, M M, and D K Morrison. 2007. "Integrating Signals from RTKs to ERK/MAPK.” Oncogene 26 (22): 3113-21. doi:10.1038/sj.onc.1210394. 
Medema, R H, and L Macůrek. 2012. "Checkpoint Control and Cancer." Oncogene 31 (21): 2601-13. doi:10.1038/onc.2011.451.

Ministério da Saúde, FUNASA. 2001. Manual de Diagnóstico E Tratamento de Acidentes Por Animais Peçonhentos. Edited by Assessoria de Comunicação e Educação em Saúde/Ascom/Pre/FUNASA. 2nd ed. Brasília.

Mita, Monica, and Anthony W Tolcher. 2005. "Novel Apoptosis Inducing Agents in Cancer Therapy." Current Problems in Cancer 29 (1): 8-32. doi:10.1016/j.currproblcancer.2004.11.001.

Molinari, M. 2000. "Cell Cycle Checkpoints and Their Inactivation in Human Cancer." Cell Proliferation 33 (5): 261-74. http://www.ncbi.nlm.nih.gov/pubmed/11063129.

Montecucco, C., J. M. Gutiérrez, and B. Lomonte. 2008. “Cellular Pathology Induced by Snake Venom Phospholipase A2 Myotoxins and Neurotoxins: Common Aspects of Their Mechanisms of Action." Cellular and Molecular Life Sciences 65 (18): 2897-2912. doi:10.1007/s00018-008-8113-3.

Mootha, V K, J Bunkenborg, J V Olsen, M Hjerrild, J R Wisniewski, E Stahl, M S Bolouri, et al. 2003. "Integrated Analysis of Protein Composition, Tissue Diversity, and Gene Regulation in Mouse Mitochondria." Cell 115 (5): 629-40. doi:S0092867403009267 [pii].

Mora, R, B Valverde, C Díaz, B Lomonte, and JM Gutiérrez. 2005. "A Lys49 Phospholipase $\mathrm{A}<\mathrm{Sub}>2</$ sub $>$ Homologue From $<$ I $>$ Bothrops Asper $</ \mathrm{i}>$ Snake Venom Induces Proliferation, Apoptosis and Necrosis in a Lymphoblastoid Cell." Toxicon. http://www.sciencedirect.com/science/article/pii/S0041010105000206.

Mora-Obando, Diana, Julián Fernández, Cesare Montecucco, José María Gutiérrez, and Bruno Lomonte. 2014. "Synergism between Basic Asp49 and Lys49 Phospholipase A2 Myotoxins of Viperid Snake Venom In Vitro and In Vivo." PLoS ONE 9 (10): e109846. doi:10.1371/journal.pone.0109846.

Moriwaki, Kenta, and Francis Ka Ming Chan. 2013. "RIP3: A Molecular Switch for Necrosis and Inflammation." Genes and Development 27 (15): 1640-49. doi:10.1101/gad.223321.113.

Mosmann, Tim. 1983. "Rapid Colorimetric Assay for Cellular Growth and Survival: Application to Proliferation and Cytotoxicity Assays." Journal of Immunological Methods 65 (1-2): 55-63. doi:10.1016/0022-1759(83)90303-4.

Moura-da-Silva, a M, M S Della-Casa, a S David, M T Assakura, D Butera, I Lebrun, J D Shannon, S M T Serrano, and J W Fox. 2003. "Evidence for Heterogeneous Forms of the Snake Venom Metalloproteinase Jararhagin: A Factor Contributing to Snake Venom Variability." Archives of Biochemistry and Biophysics 409 (2): 395401. http://www.ncbi.nlm.nih.gov/pubmed/12504907. 
Moura-da-Silva, A M, G D Laing, M J Paine, J M Dennison, V Politi, J M Crampton, and R D Theakston. 1996. "Processing of pro-Tumor Necrosis Factor-Alpha by Venom Metalloproteinases: A Hypothesis Explaining Local Tissue Damage Following Snake Bite." European Journal of Immunology 26 (9): 2000-2005. http://onlinelibrary.wiley.com/doi/10.1002/eji.1830260905/full.

Mueller, Lukas N., Oliver Rinner, Alexander Schmidt, Simon Letarte, Bernd Bodenmiller, Mi Youn Brusniak, Olga Vitek, Ruedi Aebersold, and Markus Müller. 2007. "SuperHirn - A Novel Tool for High Resolution LC-MS-Based Peptide/protein Profiling." Proteomics 7 (19): 3470-80. doi:10.1002/pmic.200700057.

Murakami, M, and I Kudo. 2002. "Phospholipase A2." Journal of Biochemistry. http://jb.oxfordjournals.org/content/131/3/285.short.

Murakami, Tatsuo, Nobuyuki Kamikado, Ryo Fujimoto, Kazuhiko Hamaguchi, Hitomi Nakamura, Takahito Chijiwa, Motonori Ohno, and Naoko Oda-Ueda. 2011. "A [Lys ${ }^{49}$ ]phospholipase $\mathrm{A}_{2}$ from Protobothrops Flavoviridis Venom Induces Caspase-Independent Apoptotic Cell Death Accompanied by Rapid PlasmaMembrane Rupture in Human Leukemia Cells." Bioscience, Biotechnology, and Biochemistry 75 (5): 864-70. doi:10.1271/bbb.100783.

Murphy, D, K M Detjen, M Welzel, B Wiedenmann, and S Rosewicz. 2001. "InterferonAlpha Delays S-Phase Progression in Human Hepatocellular Carcinoma Cells via Inhibition of Specific Cyclin-Dependent Kinases." Hepatology (Baltimore, Md.) 33 (2): 346-56. doi:10.1053/jhep.2001.21749.

Nagaraj, Nagarjuna, Jacek R Wisniewski, Tamar Geiger, Juergen Cox, Martin Kircher, Janet Kelso, Svante Pääbo, and Matthias Mann. 2011. "Deep Proteome and Transcriptome Mapping of a Human Cancer Cell Line." Molecular Systems Biology 7 (548): 1-8. doi:10.1038/msb.2011.81.

Nair, Dileep G, Bryan G Fry, Paul Alewood, Prakash P Kumar, and R Manjunatha Kini. 2007. "Antimicrobial Activity of Omwaprin, a New Member of the Waprin Family of Snake Venom Proteins." The Biochemical Journal 402 (1): 93-104. doi:10.1042/BJ20060318.

Neiva, Kathleen G, Zhaocheng Zhang, Marta Miyazawa, Kristy A Warner, Elisabeta Karl, and Jacques E Nör. 2009. "Cross Talk Initiated by Endothelial Cells Enhances Migration and Inhibits Anoikis of Squamous Cell Carcinoma Cells through STAT3/Akt/ERK Signaling." Neoplasia (New York, N.Y.) 11 (6): 583-93. doi:10.1593/neo.09266.

Nie, Lei, Gang Wu, David E Culley, Johannes C M Scholten, and Weiwen Zhang. 2007. "Integrative Analysis of Transcriptomic and Proteomic Data: Challenges, Solutions and Applications." Critical Reviews in Biotechnology 27 (2): 63-75. doi:10.1080/07388550701334212.

Nishimoto, Satoko, and Eisuke Nishida. 2006. "MAPK Signalling: ERK5 versus ERK1/2." EMBO Reports 7 (8): 782-86. doi:10.1038/sj.embor.7400755. 
Nunes, E. S., M. A. A. Souza, A. F.M. Vaz, T. G. Silva, J. S. Aguiar, A. M. Batista, Maria M.P. Guerra, Miriam C. Guarnieri, Luana C.B.B. Coelho, and Maria T.S. Correia. 2012. "Cytotoxic Effect and Apoptosis Induction by Bothrops Leucurus Venom Lectin on Tumor Cell Lines." Toxicon 59 (7-8). Elsevier Ltd: 667-71. doi:10.1016/j.toxicon.2012.03.002.

Nunes, Fernanda P B, Sandra C Sampaio, Marcelo L Santoro, and Maria Cristina C Sousa-e-Silva. 2007. "Long-Lasting Anti-Inflammatory Properties of Crotalus Durissus Terrificus Snake Venom in Mice." Toxicon: Official Journal of the International Society on Toxinology 49 (8): 1090-98. doi:10.1016/j.toxicon.2007.01.017.

Oguiura, Nancy, Malvina Boni-Mitake, Regina Affonso, and Guolong Zhang. 2011. "In Vitro Antibacterial and Hemolytic Activities of Crotamine, a Small Basic Myotoxin from Rattlesnake Crotalus Durissus." The Journal of Antibiotics 64 (4): 327-31. doi:10.1038/ja.2011.10.

Oliveira, J. C. R., H. Montes de Oca, M. M. Duarte, C. R. Diniz, and C. L. Fortes-Dias. 2002. "Toxicity of South American Snake Venoms Measured by an in Vitro Cell Culture Assay." Toxicon 40 (3): 321-25.

Ong, Shao-En, Blagoy Blagoev, Irina Kratchmarova, Dan Bach Kristensen, Hanno Steen, Akhilesh Pandey, and Matthias Mann. 2002. "Stable Isotope Labeling by Amino Acids in Cell Culture, SILAC, as a Simple and Accurate Approach to Expression Proteomics." Molecular \& Cellular Proteomics : MCP 1 (5): 376-86. doi:10.1074/mcp.M200025-MCP200.

Organization, World Health. 2014. GLOBAL STATUS REPORT on Noncommunicable Diseases 2014. Edited by A. Alwan. Geneva, Switzerland.: World Health Organization. http://whqlibdoc.who.int/publications/2011/9789240...

Panini, S R, L Yang, A E Rusinol, M S Sinensky, J V Bonventre, and C C Leslie. 2001. "Arachidonate Metabolism and the Signaling Pathway of Induction of Apoptosis by Oxidized LDL/oxysterol." Journal of Lipid Research 42 (10): 1678-86.

Papo, N, and Y Shai. 2005. "Host Defense Peptides as New Weapons in Cancer Treatment." Cellular and Molecular Life Sciences: CMLS 62 (7-8): 784-90. doi:10.1007/s00018-005-4560-2.

Parkin, D M, P Pisani, and J Ferlay. 1999. “Global Cancer Statistics.” CA Cancer J Clin 49 (2): 1,33-64. doi:10.3322/caac.20107.Available.

Patiño, Arley C, Jaime a Pereañez, Vitelbina Núñez, Dora M Benjumea, Maritza Fernandez, Alexandra Rucavado, Libia Sanz, and Juan J Calvete. 2010. "Isolation and Biological Characterization of Batx-I, a Weak Hemorrhagic and Fibrinogenolytic PI Metalloproteinase from Colombian Bothrops Atrox Venom." Toxicon: Official Journal of the International Society on Toxinology 56 (6). Elsevier Ltd: 936-43. doi:10.1016/j.toxicon.2010.06.016. 
Paulo, Universidade De São, and Elisângela Aparecida Aragão. 2005. "Efeito Bactericida de Fosfolipases A 2 -Lys49: O Papel Da Região C-Terminal Na Atividade de Bothropstoxina-I Em Membranas Biológicas E Artificiais . Efeito Bactericida de Fosfolipases A 2 -Lys49: O Papel Da Região C-Terminal Na Atividade de Bothropstoxi."

Pedersen, Susanne K., Jenny L. Harry, Lucille Sebastian, Jasmine Baker, Mathew D. Traini, John T. McCarthy, Abi Manoharan, et al. 2003. "Unseen Proteome: Mining below the Tip of the Iceberg to Find Low Abundance and Membrane Proteins." Journal of Proteome Research 2 (3): 303-11. doi:10.1021/pr025588i.

Peres, C.M., and R. Curi. 2005. Como Cultivar Células. Guanabara. Rio de Janeiro.

Peyssonnaux, Carole, and Alain Eychène. 2001. "The Raf/MEK/ERK Pathway: New Concepts of Activation." Biology of the Cell 93 (1-2): 53-62. doi:10.1016/S02484900(01)01125-X.

Polgár, J, E M Magnenat, M C Peitsch, T N Wells, and K J Clemetson. 1996. “Asp-49 Is Not an Absolute Prerequisite for the Enzymic Activity of Low-M(r) Phospholipases A2: Purification, Characterization and Computer Modelling of an Enzymically Active Ser-49 Phospholipase A2, Ecarpholin S, from the Venom of Echis Carinatus Sochurek." The Biochemical Journal 319 ( Pt 3 (6): 961-68. http://www.ncbi.nlm.nih.gov/pubmed/1217882.

Polyak, K, Y Xia, J L Zweier, K W Kinzler, and B Vogelstein. 1997. “A Model for p53Induced Apoptosis." Nature 389 (6648): 300-305. doi:10.1038/38525.

Ponzoni, M, and P Cornaglia-Ferraris. 1993. "Interferon-Gamma-Stimulated and GTP-Binding-Proteins-Mediated Phospholipase A2 Activation in Human Neuroblasts." Biochem. J 294: 893-98.

Portt, Liam, Grant Norman, Caitlin Clapp, Matthew Greenwood, and Michael T. Greenwood. 2011. "Anti-Apoptosis and Cell Survival: A Review." Biochimica et Biophysica Acta - Molecular Cell Research 1813 (1). Elsevier B.V.: 238-59. doi:10.1016/j.bbamcr.2010.10.010.

Rádis-Baptista, G. 2005. "Integrins, Cancer and Snake Toxins (mini-Review).” Journal of Venomous Animals and Toxins ..., 217-41. http://www.scielo.br/scielo.php?pid=S1678-

91992005000300002\&script=sci_arttext\&tlng=es.

Ramachandran, Nivetha, Iulia Munteanu, Peixiang Wang, Alessandra Ruggieri, Jennifer J. Rilstone, Nyrie Israelian, Taline Naranian, et al. 2013. "VMA21 Deficiency Prevents Vacuolar ATPase Assembly and Causes Autophagic Vacuolar Myopathy." Acta Neuropathologica 125 (3): 439-57. doi:10.1007/s00401-012-1073-6.

Ramanadham, Sasanka, Richard W Gross, Xianlin Han, and John Turk. 1993. "Inhibition of Arachidonate Release by Secretagogue-Stimulated Pancreatic 
Islets Suppresses Both Insulin Secretion and the Rise In. Beta.-Cell Cytosolic Calcium Ion Concentration." Biochemistry 32 (1). ACS Publications: 337-46.

Ramoni, Marco F, Paola Sebastiani, and Isaac S Kohane. 2002. "Cluster Analysis of Gene Expression Dynamics." Proceedings of the National Academy of Sciences of the United States of America 99 (14): 9121-26. doi:10.1073/pnas.132656399.

Ravagnan, L, S Gurbuxani, S a Susin, C Maisse, E Daugas, N Zamzami, T Mak, et al. 2001. "Heat-Shock Protein 70 Antagonizes Apoptosis-Inducing Factor." Nature Cell Biology 3 (9): 839-43. doi:10.1038/ncb0901-839.

Reginato, Mauricio J, Kenna R Mills, Jessica K Paulus, Danielle K Lynch, Dennis C Sgroi, Jayanta Debnath, Senthil K Muthuswamy, and Joan S Brugge. 2003. "Integrins and EGFR Coordinately Regulate the pro-Apoptotic Protein Bim to Prevent Anoikis." Nature Cell Biology 5 (8): 733-40. doi:10.1038/ncb1026.

Rodrigues, Renata S, Luiz Fernando M Izidoro, Robson J de Oliveira, Suely V Sampaio, Andreimar M Soares, and Veridiana M Rodrigues. 2009. "Snake Venom Phospholipases A2: A New Class of Antitumor Agents." Protein and Peptide Letters 16 (8): 894-98. http://www.ncbi.nlm.nih.gov/pubmed/19689415.

Rodrigues, Renata S, F Juliana, Johara Boldrini-frança, Fernando P P Fonseca, Angelo J Magro, K Braz, Juliana I Santos, et al. 2009. "Structural and Functional Properties of Bp-LAAO , a New L -Amino Acid Oxidase Isolated from Bothrops Pauloensis Snake Venom." Biochimie, 1-12. doi:10.1016/j.biochi.2008.12.004.

Ross, Philip L, Yulin N Huang, Jason N Marchese, Brian Williamson, Kenneth Parker, Stephen Hattan, Nikita Khainovski, et al. 2004. "Multiplexed Protein Quantitation in Saccharomyces Cerevisiae Using Amine-Reactive Isobaric Tagging Reagents.” Molecular \& Cellular Proteomics: MCP 3 (12): 1154-69. doi:10.1074/mcp.M400129-MCP200.

Rucinski, Boguslaw, Stefan Niewiarowski, John C Holt, Tomasz Soszka, and Karen A Knudsen. 1990. "Batroxostatin, an Arg-Gly-Asp-Containing Peptide from Bothrops Atrox, Is a Potent Inhibitor of Platelet Aggregation and Cell Interaction with Fibronectin." Biochimica et Biophysica Acta 1054 (3). Elsevier: 257-62. doi:10.1016/0167-4889(90)90096-V.

Russell, Craig, Ayesha Rahman, and Afzal R Mohammed. 2013. "Application of Genomics, Proteomics and Metabolomics in Drug Discovery, Development and Clinic." Therapeutic Delivery 4 (3): 395-413. doi:10.4155/tde.13.4.

Rust, William L, Stephen W Carper, and George E Plopper. 2002. "The Promise of Integrins as Effective Targets for Anticancer Agents." Journal of Biomedicine and Biotechnology 2 (3). Hindawi Publishing Corporation: 124-30.

Sakamoto, Shinichi, Richard O. McCann, Rajiv Dhir, and Natasha Kyprianou. 2010. "Talin1 Promotes Tumor Invasion and Metastasis via Focal Adhesion Signaling and Anoikis Resistance." Cancer Research 70 (5): 1885-95. doi:10.1158/00085472.CAN-09-2833. 
Sanders, Kate L, Anita Malhotra, and Roger S Thorpe. 2006. "Combining Molecular, Morphological and Ecological Data to Infer Species Boundaries in a Cryptic Tropical Pitviper." Biological Journal of the Linnean Society 87 (3). Wiley Online Library: 343-64.

Saraste, a, and K Pulkki. 2000. "Morphologic and Biochemical Hallmarks of Apoptosis.” Cardiovascular Research 45 (3): 528-37. http://www.ncbi.nlm.nih.gov/pubmed/10728374.

Schadt, Eric E., Cheng Li, Byron Ellis, and Wing H. Wong. 2001. "Feature Extraction and Normalization Algorithms for High-Density Oligonucleotide Gene Expression Array Data." Journal of Cellular Biochemistry 84: 120-25. doi:10.1002/jcb.10073.

Schaloske, Ralph H, and Edward a Dennis. 2006a. "The Phospholipase A2 Superfamily and Its Group Numbering System." Biochimica et Biophysica Acta 1761 (11): 1246-59. doi:10.1016/j.bbalip.2006.07.011.

Schaloske, Ralph H., and Edward A. Dennis. 2006b. "The Phospholipase A2 Superfamily and Its Group Numbering System." Biochimica et Biophysica Acta Molecular and Cell Biology of Lipids. doi:10.1016/j.bbalip.2006.07.011.

Schmeisser, Hana, Samuel B. Fey, Julie Horowitz, Elizabeth R. Fischer, Corey A. Balinsky, Kotaro Miyake, Joseph Bekisz, Andrew L. Snow, and Kathryn C. Zoon. 2013. "Type I Interferons Induce Autophagy in Certain Human Cancer Cell Lines." Autophagy 9 (5): 683-96. doi:10.4161/auto.23921.

Schulz, Thomas C, Anna Maria Swistowska, Ying Liu, Andrzej Swistowski, Gail Palmarini, Sandii N Brimble, Eric Sherrer, Allan J Robins, Mahendra S Rao, and Xianmin Zeng. 2007. "A Large-Scale Proteomic Analysis of Human Embryonic Stem Cells.” BMC Genomics 8: 478. doi:10.1186/1471-2164-8-478.

Schwanhäusser, Björn, Dorothea Busse, Na Li, Gunnar Dittmar, Johannes Schuchhardt, Jana Wolf, Wei Chen, and Matthias Selbach. 2011. "Global Quantification of Mammalian Gene Expression Control." Nature 473 (7347): 337-42. doi:10.1038/nature10098.

Schwartz, Martin Alexander, and D E Ingber. 1994. "Integrating with Integrins." Molecular Biology of the Cell 5 (4). American Society for Cell Biology: 389.

Shaulian, Eitan, and Michael Karin. 2002. "AP-1 as a Regulator of Cell Life and Death." Nature Cell Biology 4 (5): E131-36. doi:10.1038/ncb0502-e131.

Shimizu, Shigeomi, Toku Kanaseki, Noboru Mizushima, Takeshi Mizuta, Satoko Arakawa-Kobayashi, Craig B Thompson, and Yoshihide Tsujimoto. 2004. "Role of Bcl-2 Family Proteins in a Non-Apoptotic Programmed Cell Death Dependent on Autophagy Genes." Nature Cell Biology 6 (12): 1221-28. doi:10.1038/ncb1192. 
Siegel, Rebecca, Jiemin Ma, Zhaohui Zou, and Ahmedin Jemal. 2014. "Cancer Statistics, 2014." CA: A Cancer Journal for Clinicians 64 (1): 9-29. doi:10.3322/caac.21208.

Silva, Vinícius Xavier da, and Miguel Trefaut Rodrigues. 2008. "Taxonomic Revision of the Bothrops Neuwiedi Complex (Serpentes, Viperidae) with Description of a New Species." Phyllomedusa 7 (May 2006): 45-90. http://www.revistasusp.sibi.usp.br/pdf/philo/v7n1/v7n1a05.pdf.

SILVA, RJDA, D Fecchio, and B Barraviera. 1996. "Antitumor Effect of Snake Venoms." Journal of Venomous Animals and Toxins 2 (2): 79-90. http://www.scielo.br/scielo.php?pid=S010479301996000200002\&script=sci_arttext\&tlng=es.

Simon, Manuel M., Arnold Reikerstorfer, Agatha Schwarz, Christine Krone, Thomas A. Luger, Marja Jäättelä, and Thomas Schwarz. 1995. "Heat Shock Protein 70 Overexpression Affects the Response to Ultraviolet Light in Murine Fibroblasts: Evidence for Increased Cell Viability and Suppression of Cytokine Release." Journal of Clinical Investigation 95 (3): 926-33. doi:10.1172/JCI117800.

Soares, A M, R Guerra-Sá, C R Borja-Oliveira, V M Rodrigues, L Rodrigues-Simioni, V Rodrigues, M R Fontes, B Lomonte, J M Gutiérrez, and J R Giglio. 2000. "Structural and Functional Characterization of BnSP-7, a Lys49 Myotoxic Phospholipase A(2) Homologue from Bothrops Neuwiedi Pauloensis Venom." Archives of Biochemistry and Biophysics 378 (2): 201-9. doi:10.1006/abbi.2000.1790.

Soares, AM, and JR Giglio. 2003. "Chemical Modifications of Phospholipases A 2 from Snake Venoms: Effects on Catalytic and Pharmacological Properties." Toxicon 42:

855-68. http://www.sciencedirect.com/science/article/pii/S004101010300326X.

Somasekhar, Madhu B, and Jack Gorski. 1988. "An Estrogen-Responsive Element from the 5'-Flanking Region of the Rat Prolactin Gene Functions in MCF-7 but Not in HeLa Cells." Gene 69 (1): 23-28. http://www.sciencedirect.com/science/article/pii/0378111988903745.

Srichai, Manakan Betsy, and Roy Zent. 2010. "Integrin Structure and Function." In Cell-Extracellular Matrix Interactions in Cancer, edited by R Zent and A Pozzi, 13:314. doi:10.1007/978-1-4419-0814-8_2.

Stábeli, Rodrigo G., Saulo F. Amui, Carolina D. Sant'Ana, Matheus G. Pires, Auro Nomizo, Marta C. Monteiro, Pedro R.T. Romão, et al. 2006. "Bothrops Moojeni Myotoxin-II, a Lys49-Phospholipase A2 Homologue: An Example of Function Versatility of Snake Venom Proteins." Comparative Biochemistry and Physiology Part C: Toxicology \& Pharmacology, 371-81. http://www.sciencedirect.com/science/article/pii/S1532045605002565.

Stahl-Zeng, Jianru, Vinzenz Lange, Reto Ossola, Katrin Eckhardt, Wilhelm Krek, Ruedi Aebersold, and Bruno Domon. 2007. "High Sensitivity Detection of Plasma 
Proteins by Multiple Reaction Monitoring of N-Glycosites." Molecular \& Cellular Proteomics : MCP 6 (10): 1809-17. doi:10.1074/mcp.M700132-MCP200.

Sun, Grace Y., Lloyd A. Horrocks, and Akhlaq A. Farooqui. 2007. “The Roles of NADPH Oxidase and Phospholipases A2 in Oxidative and Inflammatory Responses in Neurodegenerative Diseases." Journal of Neurochemistry. doi:10.1111/j.14714159.2007.04670.x.

Sun, Liming, Huayi Wang, Zhigao Wang, Sudan He, She Chen, Daohong Liao, Lai Wang, et al. 2012. "Mixed Lineage Kinase Domain-like Protein Mediates Necrosis Signaling Downstream of RIP3 Kinase." Cell 148 (1-2): 213-27. doi:10.1016/j.cell.2011.11.031.

Swenson, Stephen, Fritz Costa, Radu Minea, Russell P Sherwin, William Ernst, Gary Fujii, Dongyun Yang, and Francis S Markland. 2004. "Intravenous Liposomal Delivery of the Snake Venom Disintegrin Contortrostatin Limits Breast Cancer Progression." Molecular Cancer Therapeutics 3 (4): 499-511.

Tanaka, Nobuyuki, Masahito Kamanaka, Hervé Enslen, Chen Dong, Mark Wysk, Roger J. Davis, and Richard A. Flavell. 2002. "Differential Involvement of p38 Mitogen-Activated Protein Kinases MKK3 and MKK6 in T-Cell Apoptosis." EMBO Reports 3 (8): 785-91. doi:10.1093/embo-reports/kvf153.

Tang, Chih-Hsin, Rong-Sen Yang, Chao-Zong Liu, Tur-Fu Huang, and Wen-Mei Fu. 2004. "Differential Susceptibility of Osteosarcoma Cells and Primary Osteoblasts to Cell Detachment Caused by Snake Venom Metalloproteinase Protein." Toxicon 43 (1). Elsevier: 11-20.

Tanjoni, I, R Weinlich, M S Della-Casa, P B Clissa, R F Saldanha-Gama, M S de Freitas, C Barja-Fidalgo, G P Amarante-Mendes, and a M Moura-da-Silva. 2005. "Jararhagin, a Snake Venom Metalloproteinase, Induces a Specialized Form of Apoptosis (anoikis) Selective to Endothelial Cells." Apoptosis : An International Journal on Programmed Cell Death 10 (4): 851-61. doi:10.1007/s10495-0052945-1.

Tian, Hong-Yu, Ke-Hua Zhang, Xia Gao, Wei-Wei Lei, Liang Zhang, Mei-Lan Yu, JianGuo Song, and Fu-Kun Zhao. 2009. "Comparative Proteomic Analysis of Cell Cycle-Dependent Apoptosis Induced by Transforming Growth Factor-Beta." Biochimica et Biophysica Acta 1794 (10). Elsevier B.V.: 1387-97. doi:10.1016/j.bbapap.2009.05.003.

Van den Bergh, Gert, and Lutgarde Arckens. 2005. "Recent Advances in 2D Electrophoresis: An Array of Possibilities." Expert Review of Proteomics 2 (2): 243-52. doi:10.1586/14789450.2.2.243.

Van der Flier, Arjan, and Arnoud Sonnenberg. 2001. "Function and Interactions of Integrins." Cell and Tissue Research $305 \quad$ (3): 285-98. doi:10.1007/s004410100417. 
Vercauteren, Freya G G, John J M Bergeron, Frans Vandesande, Lut Arckens, and Rémi Quirion. 2004. "Proteomic Approaches in Brain Research and Neuropharmacology." European Journal of Pharmacology. doi:10.1016/j.ejphar.2004.07.039.

Vermeulen, Katrien, Zwi N Berneman, and Dirk R Van Bockstaele. 2003. "Cell Cycle and Apoptosis." Cell Proliferation 36 (3): 165-75. http://www.ncbi.nlm.nih.gov/pubmed/12814432.

Vogel, Christine, Raquel de Sousa Abreu, Daijin Ko, Shu-Yun Le, Bruce A Shapiro, Suzanne C Burns, Devraj Sandhu, Daniel R Boutz, Edward M Marcotte, and Luiz O Penalva. 2010. "Sequence Signatures and mRNA Concentration Can Explain Two-Thirds of Protein Abundance Variation in a Human Cell Line." Molecular Systems Biology 6: 400. doi:10.1038/msb.2010.59.

Vyas, VK, Keyur Brahmbhatt, Hardik Bhatt, and Utsav Parmar. 2013. "Therapeutic Potential of Snake Venom in Cancer Therapy: Current Perspectives." Asian Pacific Journal of Tropical Biomedicine 3 (2): 156-62. http://www.sciencedirect.com/science/article/pii/S2221169113600428.

Wang, Runhua, R Manjunatha Kini, and Max C M Chung. 1999. "Rhodocetin, a Novel Platelet Aggregation Inhibitor from the Venom of Calloselasma Rhodostoma (Malayan Pit Viper): Synergistic and Noncovalent Interaction between Its Subunits." Biochemistry 38 (23). ACS Publications: 7584-93.

Wang, Zi-Bing, Yu-Qing Liu, and Yu-Fang Cui. 2005. "Pathways to Caspase Activation." Cell Biology International $29 \quad$ (7): 489-96. doi:10.1016/j.cellbi.2005.04.001.

Weston, Claire R., and Roger J. Davis. 2007. "The JNK Signal Transduction Pathway." Current Opinion in Cell Biology 19 (2): 142-49. doi:10.1016/j.ceb.2007.02.001.

Whitmarsh, Alan J. 2007. "Regulation of Gene Transcription by Mitogen-Activated Protein Kinase Signaling Pathways.” Biochimica et Biophysica Acta 1773 (8): 1285-98. doi:10.1016/j.bbamcr.2006.11.011.

Wilmes, Anja, Alice Limonciel, Lydia Aschauer, Konrad Moenks, Chris Bielow, Martin O. Leonard, Jeremy Hamon, et al. 2013. "Application of Integrated Transcriptomic, Proteomic and Metabolomic Profiling for the Delineation of Mechanisms of Drug Induced Cell Stress." Journal of Proteomics 79: 180-94. doi:10.1016/j.jprot.2012.11.022.

Wolters, D. A., M. P. Washburn, and J. R. Yates. 2001. "An Automated Multidimensional Protein Identification Technology for Shotgun Proteomics." Analytical Chemistry 73 (23): 5683-90. doi:10.1021/ac010617e.

Wong, Kwong-Kwok. 2009. "Recent Developments in Anti-Cancer Agents Targeting the Ras/Raf/MEK/ERK Pathway." Recent Patents on Anti-Cancer Drug Discovery 4 (1): 28-35. doi:10.2174/157489209787002461. 
World Health Organization, WHO. $2013 . \quad$ "Cancer." Http://www.who.int/topics/cancer/en/.

Wüster, Wolfgang, Marcelo R Duarte, and Maria da Graça Salomão. 2005. "Morphological Correlates of Incipient Arboreality and Ornithophagy in Island Pitvipers, and the Phylogenetic Position of Bothrops Insularis." Journal of Zoology 266 (1). Wiley Online Library: 1-10.

XingDing, Zhou, R M Kini, R Doley, and S P Mackessy. 2009. "Snake Venom Phospholipase A2 Enzymes." In Handbook of Venoms and Toxins of Reptiles, 173-215. CRC Press Inc.

Yagami, Tatsurou, Keiichi Ueda, Kenji Asakura, Toshiyuki Sakaeda, Satoshi Hata, Takayuki Kuroda, Gaku Sakaguchi, Naohiro Itoh, Yutaka Hashimoto, and Yozo Hori. 2003. "Porcine Pancreatic Group IB Secretory Phospholipase A2potentiates Ca2+ Influx through L-Type Voltage-Sensitive Ca2+ Channels." Brain Research 960 (1-2): 71-80. doi:10.1016/S0006-8993(02)03775-7.

Yamamoto, K, H Ichijo, and S J Korsmeyer. 1999. "BCL-2 Is Phosphorylated and Inactivated by an ASK1/Jun N-Terminal Protein Kinase Pathway Normally Activated at G(2)/M." Molecular and Cellular Biology 19 (12): 8469-78.

Yerlikaya, Azmi, Emrah Okur, Ahmet Tarık Baykal, Ceyda Acılan, İhsan Boyacı, and Engin Ulukaya. 2015. "A Proteomic Analysis of p53-Independent Induction of Apoptosis by Bortezomib in 4T1 Breast Cancer Cell Line." Journal of Proteomics 113: 315-25. doi:10.1016/j.jprot.2014.09.010.

Yorimitsu, T, and D J Klionsky. 2005. "Autophagy: Molecular Machinery for SelfEating." Cell Death and Differentiation 12 Suppl 2: 1542-52. doi:10.1038/sj.cdd.4401765.

Zong, Wei Xing, and Craig B. Thompson. 2006. "Necrotic Death as a Cell Fate." Genes and Development 20 (1): 1-15. doi:10.1101/gad.1376506.

Zouari-Kessentini, Raoudha, José Luis, Aida Karray, Olfa Kallech-Ziri, Najet SrairiAbid, Amine Bazaa, Erwann Loret, Sofiane Bezzine, Mohamed El Ayeb, and Naziha Marrakchi. 2009. "Two Purified and Characterized Phospholipases A2 from Cerastes Cerastes Venom, That Inhibit Cancerous Cell Adhesion and Migration." Toxicon : Official Journal of the International Society on Toxinology 53 (4). Elsevier Ltd: 444-53. doi:10.1016/j.toxicon.2009.01.003. 